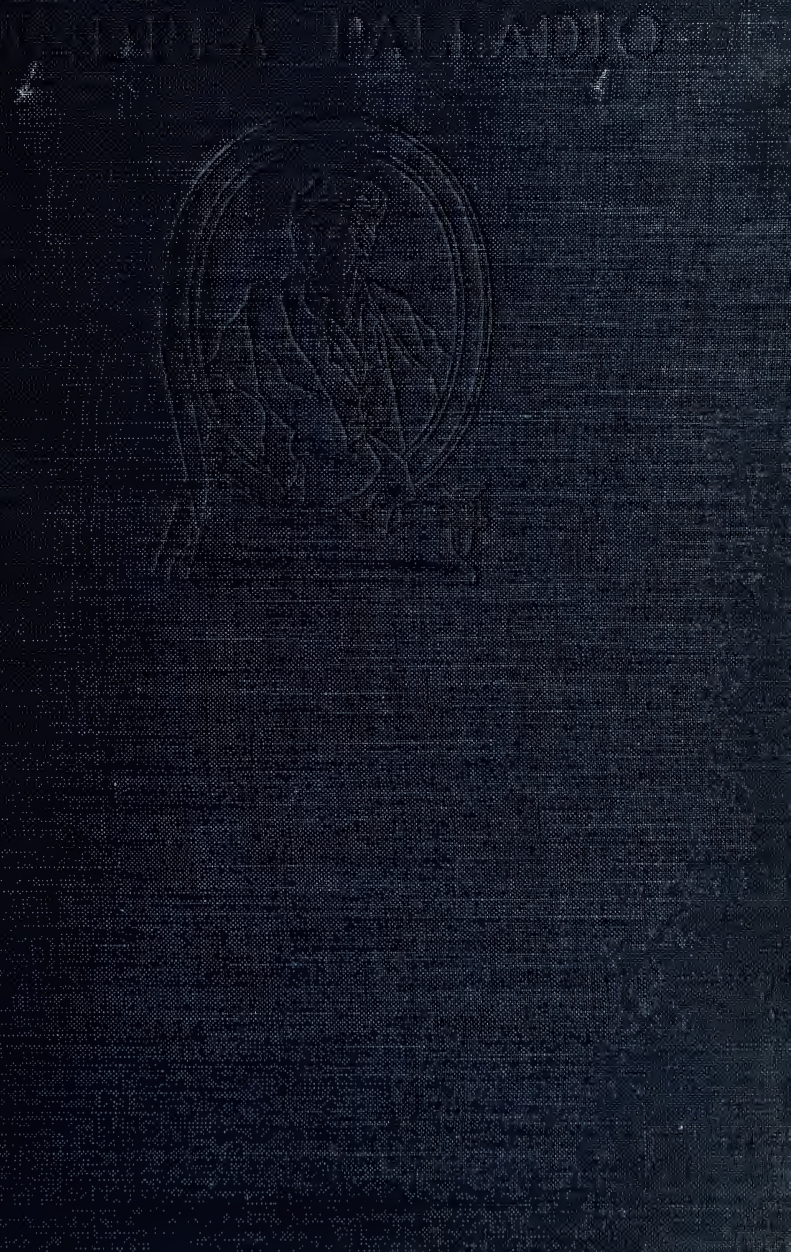


Librairie des Arts Decoratifs \& Industriels

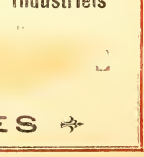

$\Leftrightarrow B H U K L L E S$ 


ANDREA PALLADIO 



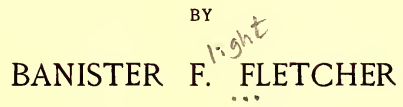

A.R.I.B.A., ARCHITECT

LECTURER ON ARCHITECTURE AT THE ARCHITECTURAL ASSOCIATION ; UNIVERSITY EXTENSION LECTURER ON ARCHITECTURE; AND FORMERLY LECTURER AT KING'S COLLEGE, LONDON; R.I.B.A. GODWIN BURSAR, I893; TITE MEDALLIST, r895; ESSAY MEDALLIST, ז896; PAST VICE-PRESIDENT OF THE ARCHITECTURAL ASSOCIATION
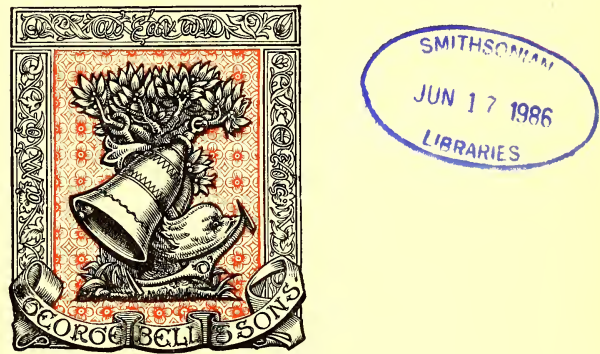

\section{LONDON}

\section{GEORGE BELL AND SONS}

I902 
CHISWICK PRESS: CHARLES WHITTINGHAM AND CO. TOOKS COURT, CHANCERY LANE, LONDON. 


\section{FOREWORDS}

$\mathrm{M}$

ANY attempts have been made at various times to write the life of this great architect of the Renaissance, but it has been difficult to glean from any of these sources authentic details of his daily life which might prove of interest to the general reader.

After a long and careful consideration of these biographies, I am inclined to agree with Calvi, ${ }^{1}$ that no one has ever written a better one than Paolo Gualdo, whose fatherNicolo Gualdo-was a contemporary of Palladio, living at Vicenza at the same time. He must consequently have had many opportunities of acquiring accurate information regarding the incidents of his life; holding much the same position in regard to Palladio as Manetti held in regard to Brunelleschi, though unfortunately Paolo Gualdo (whose work is compiled from notes taken by his father at the time) does not give the same detailed account which Manetti furnishes of the life of the great Brunelleschi.

Furthermore, knowing the high position held by the Gualdo family, and their great integrity, I am in favour of accepting his statements with all confidence, and some of the information found in his book is therefore given here. ${ }^{2}$

I am indebted also to Vittoria Barichella, whose excellent, though brief, work ${ }^{3}$ has furnished me with interesting

1 Calvi, G. A. P., “Bibl. degli Scrittori,” Vicenza, I772.

" Gualdo, Paolo, "Vita di A. Palladio." Montanari, Padoua, I749.

" "Andrea Palladio e la sua Scuola," Lonigo, 1880. 
matter, and displays a careful study of Palladio's methods, together with an ardent admiration for his genius and personality. Among other authors laid under contribution will be found Temanza, ${ }^{1}$ Magrini, ${ }^{2}$ Todeschini, ${ }^{3}$ and Octave Bertotti Scamozzi. ${ }^{4}$ This latter's learned and important work is indeed a labour deserving of a rich reward, and should rank as the best guide to our master's designs. Bertotti's measurements of the various buildings have been, in the main, followed in this work.

I have endeavoured to append a complete list of all the sources from which information has been derived, but if by any oversight a name has been omitted I offer my sincere apology. Though the details of Andrea Palladio's private life are not of paramount importance, and cannot affect his great work, we should nevertheless have been glad to learn a few more of the episodes and early influences which contributed to the development of his character. However, we can but rejoice that in regard to his life's labour, there is ample testimony handed down to us-not only in his own writings and those of the various authors on the subject, but in the edifices which still remain to remind us of his great genius. There is much diversity of opinion among the various authors, including Bertotti, regarding the authenticity of many of the designs reputed to be his, but we do not purpose wearying the reader unnecessarily with these controversies, nor yet to load the text with complex footnotes, which are in many instances mere pedagogy, and but serve to confuse the mind. Many of Palladio's original

1 Temanza, T., "Vita di A. Palladio." Venezia, Palese, I778.

${ }^{2}$ Magrini, A., "Memorie intorno la vita di A. Palladio," I 845.

s Todeschini, Prof. Guiseppe, "Parere sulla sepoltura del A. Palladio, del Agosto," I 844. (MSS. nella Bertoliana.)

"Scamozzi, O. B., "Les Bâtimens et les Desseins de A. Palladio, recueillis et illustrés," 4 vols., with plates, Vicence, 1796. 
drawings and designs are at present in the library of the R.I.B.A., where they were deposited by permission of his Grace the Duke of Devonshire. A perusal of this great man's life cannot but prove of interest, both to the architect and to the student. To the architect it is especially so, because Palladio, without doubt, was the registrar of the new architecture, which still holds a first position, especially in regard to civil buildings. To him we owe the art of the fully developed English Renaissance, as introduced by Inigo Jones, Wren, Chambers and others whose edifices grace this our great city, and are also found throughout the length and breadth of the land, displaying that fine perception of proportion and purity of detail, so markedly opposed to the vulgarity of the Baroco manner affected by some of the continental architects. There is also a sobriety in the architecture of England, harmonizing well with both our climate and the national taste.

To the student our author's career forms an example of how, as Leoni ${ }^{1}$ informs us, a man " of mean extraction " can by force of natural inclination, aided by application, become one of the greatest men of his day, creating an honoured reputation, and leaving to posterity ennobling examples of that art to which he devoted his life.

I am indebted to Mrs. Hamilton Hall for assistance in looking up authorities in regard to details of the life of Palladio, and for help in revision of the text generally.

\section{Banister F. Fletcher.}

29, New Bridge Street,

LONDON, E.C.

1 “Architecture of Andrea Palladio," translated by Leoni, London, 1742. 
Note.-In regard to the measurements referring to buildings, etc., throughout the volume, I have reduced all these to English feet, but on the illustrations taken from Palladio's and Bertotti's books, they refer to the Vicenza foot. An English foot is to the Vicenza foot as $\mathrm{I}$ ft. $\mathrm{I} \frac{3}{4}$ in. is to I foot, so that by adding one-seventh to a measurement in Vicentine feet, we obtain the equivalent in English feet. 


\section{LIST OF CONTENTS}

CHAPTER

I. Birth and Parentage.

PAGE

II. Manhood And Environment . . 5

III. Palladio as an Architect . . . I 2

IV. Public Bulldings . . . . . 2 2 I

Bridges . . . . . 22

The Basilica (Palazzo della Ragione) at Vicenza . . . . 26

The Teatro Olimpico at Vicenza . $\quad 3^{1}$

The Theatre at Parma . . . . 37

The Monument to the Conte Leonardo Porto . . . . . . . 37

V. Town Houses . . . . . . . 39

The Palazzo Chiericati . . . . 40

The Palazzo Thiene . . . . 42

The Palazzo Valmarana . . . . . 44

House for Signor Guioglio Capra . . 47

The Palazzo Barbarano . . . . . 47

The Palazzo Porto . . . . 50

The Palazzo del Consiglio . . . 52

The Casa del Diavolo . . . . 53

Other Town Houses, whose authorship is doubtful . . . . . . 55

VI. Country Houses . . . . . . . 59

The Villa Capra . . . 6I

House at Bagnolo for the Conti Pisani . 64

House at La Frata for the Nobile Francisco Badoero . . . . . 64 
VI. Country Houses-continued.

House at Casalto for the Nobile Marco Zeno . . . . . 65

House at Gambarare for the Nobili Nicolo and Luigi de Foscari . . . . 65

House at Maser for the Monsignore Daniele Barbero .

House at Montagnana for the Nobile Francisco Pisano

House at Piombino for the Nobile Giorgio Cornaro . . . . . 68

House at Morocco for Leonardo Mocenigo 68

House at Panzolo for Leonardo Emo . 69

House at Final for the Nobile Biagio

House at Ghizzole for Signor Girolamo Ragona . . . . . 70

House at Pogliana for the Conte Pogliana 70

House at Liziera for Signor Giovanni Francesco Valmarana . . . . 7 I

House at Meledo for the Conti Francesco and Ludovico Trissini

House at Campiglia for Signor Marco Repeta

House at Cigogna for the Conti Eduardo and Teodoro Thiene

House at Angarano for the Conte Giacomo Angarano

House at Quinto for the Conte Ottavo Thiene.

House at Lonedo for Signor Girolamo de' Godi 
VI. Country Houses-continued.

House at Santa Sophia for the Conte Marc Antonio Sarego .

House at La Miga for the Conte Annibale Sarego . . . . . 76

Other Houses attributed to Palladio . $\quad 76$

VII. Churches . . . . . . . . 8I

Il Redentore, Venice . . . . 83

S. Giorgio Maggiore, Venice . . 85

Church at Maser . . . . $\quad 87$

Church of S. Lucia, Venice . $\quad$. 88

Church of Le Zitelle, Venice . $\quad . \quad 88$

Façade of S. Francesca della Vigna,

Venice

89

Design for the Façade of S. Petronio, Bologna . . . . . 90

Convent of La Carità, Venice . . 93

VIII. Literary Works and Drawings . . 94

The Proportions of the Orders according to Palladio

The Various Editions and Translations of Palladio's Works . . . . $\quad$ I04

The Burlington-Devonshire Collection of Palladio's Drawings . . . 106

IX. Palladio's Family and Declining Days il

$X$. The Influence of Palladio and His

SCHOOL . . . . . II6

Biblography . . . . . . 129 



\section{LIST OF ILLUSTRATIONS}

* Indicates that the illustration is taken from "The Architecture of A. Palladio," by Giacomo Leoni, London, 1742.

† Indicates that the illustration is taken from "Les Bâtimens et les Desseins de André Palladio, par Octave Bertotti Scamozzi, Vicenza, I796."

Those unmarked are reproduced from photographs.

I. * Portrait of Palladio, by Paolo Veronese, engraved by Picart . . . . . 6

2. †The Basilica (Palazzo della Ragione), Vicenza. Plan. . . . . I6

3. The Basilica, Vicenza. Side Elevation I8

4. † The Basilica, Vicenza. Transverse Section. 26

5. The Basilica, Vicenza. Loggia on the first floor . . . . . 28

6. The Basilica, Vicenza. General view from Piazza . . . . . . 28

7. † The Basilica, Vicenza. Details of Doric and Ionic orders to façade . . . . . 28

8. † Arco di Trionfo, Vicenza. Plan. Elevation. Section . . . . . . 30

9. Arco di Trionfo . . . . . 30

io. †Teatro Olimpico, Vicenza. Plan . . 32

i I. Teatro Olimpico, Vicenza. General view of Interior 
i2. Teatro Olimpico, Vicenza. View of central part of scene

I3. Monument to the Conte Leonardo Porto, in S. Lorenzo, Vicenza . . . . 36

i4. †onument to the Conte Leonardo Porto, VICENZA. Details . . . .

i5. The Palazzo Municipale, Brescia. Window dressings by Palladio . . . . . $3^{8}$

i6. Palazzo Chiericati, Vicenza . . . 40

I7. * Palazzo Thiene . . . . . . . 42

18. †Palazzo Valmarana, Vicenza. Plan. . 44

i9. Palazzo Valmarana, Vicenza . . . 44

20. Palazzo Barbarano, Vicenza . . . 46

2 I. * Palazzo Porto, Vicenza. Detail of Courtyard . . . . . . . . 48

22. Palazzo Porto, Vicenza . . . 50

23. Palazzo del Consiglio, Vicenza . 52

24. The House of Palladio, Vicenza . 56

25. †The Villa Capra (The "Rotonda”) near Vicenza. Plan . . . . . . 58

26. T The Villa Capra, near Vicenza. Elevation. 60

27. † The Villa Capra, near Vicenza. Section. 62

28. The Villa Capra, near Vicenza. General view . . . . . . . . . . 64

29. † The Villa Giacomelit, at Maser, Province of Treviso. Plan . . . . . 66

30. The Villa Giacomelli, at Maser, Province of Treviso. General view . . . 68

31. * House AT Meledo . . . . . . 72

32. † Il Redentore, Venice. Plan . . . 80

33. Il Redentore, Venice. Front view . . 82

34. † Il Redentore, Venice. Front Elevation . 82

35. † Il Redentore, Venice. Section . . . 82 
36. †S. Giorgio Maggiore, Venice. Plan .

PAGE

37. S. Giorgio Maggiore, Venice. Interior

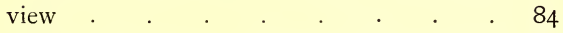

38. S. Giorgio Maggiore, Venice. General view. 84

39. The Villa Giacomelli at Maser, Province of Treviso. General view of the Gardens and Church . . . . . . .

40. The Villa Giacomelli at Maser. View of Church .

4I. †. Petronio, Bologna. Palladio's third design for the façade

42. †. Petronio, Bologna. Palladio's fourth design for the façade

43. * The Five Orders of Architecture after Palladio. General proportions . . . 96

44. * The Doric ORder. Proportions of capital

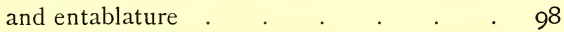

45. * The Doric Order. Arcade with half columns on pedestals. $. \quad . \quad . \quad . \quad . \quad$.

46. * The Ionic ORder. General proportions of a colonnade. . . . . . . IOO

47. * The Ionic Order. Arcade with half columns on pedestals . . . . . . . . 100

48. * The Ionic Order. Details of capital showing setting out of volute, etc. . . . . . 102

49. * The Ionic Order. Detail of entablature and upper part of column . . . . . . 102

5o. * The Corinthian Order. General proportions of a colonnade . . . . . . 104

5I. * The Corinthian Order. Arcade with half columns on pedestals . . . . . . 104

52. * The Corinthian Order. Details of base of columns and pedestal and impost of arcade. 106 
53. *The Corinthian Order. Details of entablature and upper part of column . . . . 106

54. * The Composite Order. General proportions of a colonnade . . . . . 108

55. * The Composite Order. Arcade with half columns on pedestals . . . . . . 108

56. *The Composite Order. Details of entablature and upper part of column . . . I IO 


\title{
ANDREA PALLADIO
}

\author{
CHAPTER I \\ BIRTH AND PARENTAGE
}

$\mathrm{O}^{\mathrm{r}}$ F the early life and parentage of Andrea Palladio (described by some as the Newton of architecture) there exists but scant information of an authentic character.

We find that all his biographers, with the exception of Paolo Gualdo, describe him as having been born in the year I5I8. These statements are in all probability based upon the authority of Bernardino Licinio, who, in painting Andrea's portrait in 154I, gave his age as twenty-three. Paolo Gualdo, however, informs us that he was born in 1508 , thus making him just ten years older. Unfortunately there is no further confirmation of this statement. We can but remark that in Calvi's opinion ${ }^{1}$ Gualdo's short and interesting "Vita di Andrea Palladio" ${ }^{2}$ was probably written from notes taken at the time by his father Nicolo Gualdo, a contemporary and also a personal friend of our master.

This small and unpretentious work enters most thoroughly into the life and work of Andrea Palladio. Gualdo belonged to an illustrious family of Vicenza, who distinguished themselves by a love of the arts, and it is easy to imagine the frequent opportunities given to both father

1 Calvi, P., "Angiolo Gabriella da S. Maria." "Bibl. degli Scrittori," Vicenza, Mosca, I772, chapter vii. p. I I.

2 Gualdo, Paolo, "Vita di A. Palladio." Montanari, Padoua, I749. 
and son of conversing with Palladio in these days. Paolo Gualdo, the son, born in 1553, was a friend of the great scientists of the day, and received in his house Tasso and Cardinal Castagna, afterwards Pope Urban VII. He took holy orders, and was selected for high office, but he humbly declined the mitre and all honours. When he died, in Padoua in I62I, his funeral was worthy of his great merits, and his remains lie in the Cathedral there.

Palladio's parents gave him the name of Andrea, as his birth fell near the festival of this popular saint, and this name was preceded by that of Giovanni, one which we are informed was hereditary in the family. This latter name prefixed to the generally known one of Andrea, and used by Magrini, dispels any doubt which existed regarding a certain Giovanni who was supposed to have assisted our master in his creation of the Basilica at Vicenza. Both Arnaldi and Temanza, ${ }^{2}$ deceived by the error of an official of the registry, who wrote, "Designum . . . presentatum per magistrum Johannen et Andream Palladium Vicentinos," endeavoured to discover this Giovanni. Temanza imagined him to be Scamozzi; Arnaldi, the architect of the Palace which was substituted for the Castle of Udine (who is also supposed to have been Giovanni Fontana and a master of Palladio). We are indebted to Magrini for the discovery of Palladio's father, whose name appears to have been Pietro, and his occupation that of a mason at Vicenza, where he died in I545. "Andreas Paladio quondam Petri," is the signature continually repeated in documents, but this in itself does not prove, as some writers believe, that Pietro

1 Doninamo, Seconda libreria, ed. 2a, Venezia, Marcolini, 1555, p. 155.

${ }^{2}$ Arnaldi, Enea, "Delle basiliche antiche e specialmente di quella di Vicenza, discorso Vicenza," Vendramini, I769, capo xiii. Temanza, "Vita di A. Palladio," citata, p. 290. 
was without a family name. Bertotti, in a list of accounts for a building to Conte Godi in Lonedo ${ }^{1}$ found a reference to a sum of six livres paid to "Messer Andrea architect, on the 26 th of august 1540 ." This appeared to prove to many that Andrea did not at this time possess a family name, but as in the same list he also appears with his family name, "presente Andrea Paladio quondam Petri," the basis of this induction is by no means a solid one.

Both Beni and Scotta inform us that Andrea derived his name of Palladio from his patron, Trissino, but there is no authentic information regarding this statement; Gualdo ${ }^{2}$ maintaining that Andrea's acquaintance with Trissino was of a much later date, when he had become a sculptor, at an age which he describes as "convenient." Though we should much like to know some of the circumstances of his boyhood, and the various influences and episodes which contributed to his success in after years, nevertheless these are but of minor importance.

All we are privileged to learn is from Palladio's own statement in "I due primi libri dell' architettura, dedica al Conte Angarano." He tells us that he early possessed a great love and natural inclination for architecture, and that, as a boy, he read Caesar's "Commentaries," and imagined and designed the bridge over the Rhine from Caesar's written description, afterwards utilizing this over the Bacchiglione, near Vicenza. Gualdo mentions that Palladio also seriously studied mathematics, which he considered an essential part of an architect's education. His humble birth is corroborated by Leoni, ${ }^{3}$ who describes him as of " mean extraction,"

${ }^{2}$ Rogito de Settembre del I 540 de notaio, B. Massaria, nel quale il Palladio, etc.

${ }^{2}$ Gualdo, P., "Vita di A. Palladio," Padoua, 1749.

3 "Architecture of A. Palladio," by Leoni, with notes by Inigo Jones, 1742 . 
adding " that in consideration of his great abilities, and as a reward for the honours he did his native city, he was made free of the same, and received into the body of the nobility." But this honour only came to Palladio when his fame was established throughout the whole of northern Italy. It is thus evident to us that his early life was a studious one, and we naturally infer that a most excellent education was conferred upon him by his faithful father, the mason Pietro, who in all probability sacrificed much to secure his son's future, intrusting him to the care of masters whose names we unfortunately do not know.

The days of Palladio's youth (and those preceding it) were eventful ones. But a very few years before his birth Savonarola, in 1482 , had started his career as a preacher in Florence, and on the 23 rd of May, 1498, was, alas! burnt as a heretic at the stake. Later, in $152 \mathrm{I}$, we read of the jewels of Pope Leo's tiara being pledged to pay his debts, and about this time, too, the great Raphael of Urbino (who was master of the works of St. Peter, and general superintendent of Antiquities) made plans to exploit the ancient works of Rome. He also, like our master, studied diligently the writings of Vitruvius, and laid down a ground-plan of the city, dividing it into fourteen regions. Then came the siege, when Rome was sacked, the Pope imprisoned, and so many valuable lives sacrificed: Goritz, Colocco, Cesi, Calvi, Baldus, and Valeriani the historian, among others. Antiquity seems to have formed the principal study in every branch of learning at this time, and Brunelleschi in Florence, Alberti in Tuscany, Michael Angelo, Perucci, Leon Leoni and Vasari all excelled in their respective writings on the subject. 


\section{CHAPTER II}

\section{MANHOOD AND ENVIRONMENT}

WHen we next discover Palladio he is a youthful sculptor at Vicenza, but of his precise age we have no information. He appears, however, to have soon deserted sculpture for that of architecture, to which he was so devoted; meanwhile also studying the works of Vitruvius and Alberti. His master at this time, it is believed, was Giovanni Fontana, the architect of the grand palace of Udine, upon which in later years Palladio was also engaged. In addition to Vitruvius and Alberti, Andrea also doubtless studied the works of Michelozzi, Cronaca, San Gallo and Mangelli; all of whom were Cinque-Cento Florentines, in favour of the Renaissance.

It was Palladio's good fortune to be born in an age pregnant with a restless ambition to continue the work of the Renaissance ; it is therefore not surprising to find him also fired with the prevailing spirit of his time. Brunelleschi's great and original efforts a century before had given the necessary impetus to the art of building, and had encouraged many others to follow his example; with results displaying a distinctive departure from the architecture of the middle ages.

In this, the fifteenth century, were formed the three great schools of architecture, the Florentine, Roman and Venetian: of the first, Brunelleschi was the master, his greatest works being the dome of the Cathedral, Santo 
Spirito and the Pitti Palace. In Rome, Baccio Pentelli had built two palaces, both considered good examples of Roman Renaissance. Bramante of Urbino will also be remembered as the designer of St. Peter's, and Peruzzi as the architect of the Villa Farnesina. Later Sansovino, the master of the Venetian School, built the Library of St. Mark, Venice (of which the Carlton Club is a modified copy), and also the magnificent Palace of the Procuratie, which Palladio especially eulogizes; this being in his opinion the most sumptuous edifice built since the time of the ancients.

When thirty-three years of age (in Gualdo's computation) Andrea was painted by Licinio. At this time he was beginning the restoration of the Basilica and the surrounding arcades at Vicenza. Temanza ${ }^{1}$ describes the portrait thus: "Face dark, eyes vivacious, dress rich, his appearance that of a genius." This painting of Licinio was formerly in the possession of George Smith, Esq., and is now in one of our Royal galleries. Many engravings of this portrait exist, including one at Vicenza. In accordance with the custom of the times Palladio possessed a patron in Gian Giorgio Trissino, whom he describes as "the ornament of our age." It was with this patron that he first visited Rome in I54I, when he was, according to Gualdo's chronology, thirty-three years of age. This would appear somewhat late to commence his practical study of architecture, but we must accept it as a fact if we take Paolo Gualdo to be correct. At any rate, Palladio must have been exceedingly industrious during his visit to Rome, as his drawings of the classic buildings in his treatise testify. Trissino was a man of wealth and many accomplishments; an orator, poet and architect. Later we find Palladio faithfully carrying out this patron's plans for the restoration of

\footnotetext{
${ }^{1}$ Temanza, S., "Vita di A. Palladio," Venezia, 1778.
} 


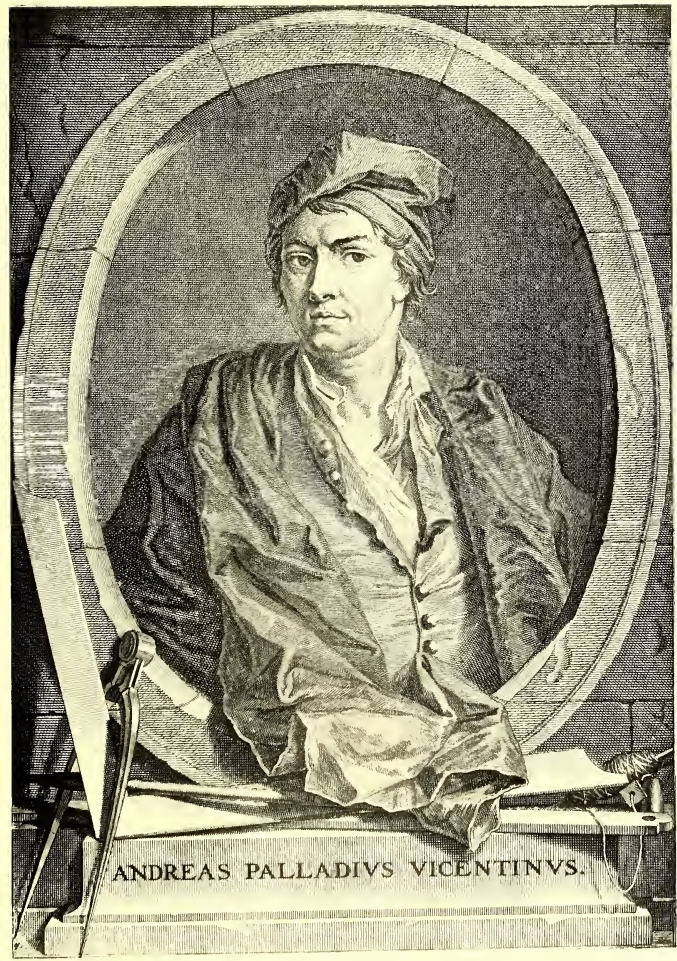

I. PILI MDIO.

FHON A PORTRUIT HY PAOLO VERONESE, LNGRAVED HY PICART. 

the Palazzo Trissino at Criccoli, which constituted his first known work. We also find that he visited at various periods Ancona, Rimini, Naples, Capua, Pola in Istria, and Nîmes. In May, I547, we also hear of his visiting Tivoli, Palestrina, Porto and Albano, returning to Vicenza in July, and taking with him nine books, entitled "L'Italia liberata dai Goti," which he presented to Ciro, son of Trissino. In I55I he is for the third time in Rome, "in the company of Venetian Gentlemen."1

We read of no patronage being extended to our master in these days by the Pope or nobles of Rome. His time there was spent in earnest researches among the ruins of her temples and edifices ; a time of hard labour, of measuring minutely and theorizing, the results of which he has handed down to posterity in his valuable writings on architecture. $\mathrm{He}$ tells us that, "I began with the utmost accuracy to measure every minute part by itself, and indeed I became so scrupulous an examiner of them, not discovering that anything of this kind is performed without the justest reason and the finest proportion, that I afterwards, not once but very often, took journeys to several parts of Italy and even out of it, that I might be able from such fragments to comprehend what the whole must needs have been, and to make draughts accordingly. I thought this an undertaking worthy of a man who considers that he was not born for himself only, but likewise for the good of others." 2 During his stay in the ancient city no doubt Palladio came often in contact with many of the great artists of the day, and must in consequence have derived additional knowledge, thereby strengthening his own convictions as to the true manner. Here he could gaze upon the great

Gualdo, P., "Vita di A. Palladio," Montanari, Padoua, I749, p. 8.

2 "Le antichita di Roma," A. Palladio, 1565 , Venice. 
achievements of Bramante and Raphael; could study the progress of the cupola of St. Peter under the masterly direction of Michael Angelo, and also see this great master's work on the Palazzo dei Conservatori. Here he also might wander where Angelo and San Gallo had wandered years before to see the Laocoon disinterred in the vineyard of Felis di Fredi, and back to gaze upon it in the gardens of the Vatican. Very few of the ancient glories of Rome remained at this time. The four gates, however, still stood, those of the Rotunda, St. Adriano, St. Cosino, and St. Agnes; the finest of all being the Rotunda, wherein the ancients endeavoured to imitate by art that kind of Corinthian metal in which the colour of gold prevailed. Letarouilly (in " Rome Moderne," Paris, I840) informs us that while Palladio was measuring here, he built an altar in the long hall of the hospital of S. Spirito, the only work of his to be seen in Rome. In these days, under Pope Leo X., Rome was gay with music and laughter; bright with an influence which was slowly but surely effacing the rust of barbarity which had so long remained on the surface of the ages, and loosening the fetters which had so long bound them in indolence. The long night was over and Art was awakening to the glorious dawn of the later Renaissance. Palladio's first recognized work appears to have been the restoration of the Palazzo Trissino at Criccoli. Later, in I540, we hear of his designing the Godi Palace at Lonedo. In 1547 he was at work on the Public Palace at Udine, called Il Castello, begun by Giovanni Fontana, stated to have been his master. In 1545 to I 549 Palladio designed the screens on three sides of the Sala della Ragione at Vicenza, this being one of his greatest achievements. Fergusson quotes this as an almost unique example of an addition of this sort to a Gothic building having proved 
a success. ${ }^{1}$ As Palladio's works are treated in the following chapters and illustrations given, as far as space will permit, a detailed treatise is superfluous here. We might mention broadly that among his churches that of Il Redentore at Venice, built in 1578 , is generally conceded to be the most beautiful of his designs ; combining both grace and simplicity. In regard to his palaces, the façade of the Thiene Palace at Vicenza is exceedingly fine. The Olympic Theatre, also at Vicenza, built of stone, was our master's last and finest effort; unfortunately he was not privileged to see its completion, for death intervened. Palladio's contemporaries living in Vicenza at this time are mentioned by him, ${ }^{2}$ " numbered among the most illustrious (whether blood or learning is considered), were Gian Giorgio Trissino, the ornament of our age; the Counts Marc Antony and Adrian di Thiene Antenor Pagello and Fabie Monza, Eliode Belli Oliviera, Barbarano, and many others." We might add that the theatre at Vicenza was inaugurated by a performance of the "Oedipus Tyrannus" of Sophocles. ${ }^{3}$

In Palladio's writings we find very interesting information regarding the architects and painters of his day. Especially does he eulogize Vasari, whom he styles "a painter and architect of great merit."

We also find mention made of Sansovino, accompanied by much praise of the buildings erected by him, as already mentioned. Sansovino was born at the end of the first century of the Renaissance. From Florence we read of his migrating to Venice, where in course of time he introduced the new style. Another architect remaining at this time in Florence was Bacio d'Agnolo, and here in 1520 he

\footnotetext{
' J. Fergusson, "History of Architecture in all Countries," 1893, etc.

2 "I quattro libri dell' Architettura," Venezia, 1570.

s See Baedeker's "Guide to Northern Italy."
} 
decorated the Palazzo Barbolini with windows and doors of pedimented form, which we are told excited the laughter of passers-by, who in derision stopped to make a genuflexion. This new form of art was to remain, for we find it copied by Raphael in the Pandolfini Palace, and also by the great maestro, Michael Angelo, in the Medici Palace. We also find later that Palladio followed their example, and it eventually became the principal characteristic of his style. On reading the fourth book of his architecture we find other contemporaries mentioned, amongst these being San Micheli, the great military architect of the Renaissance, whose special predilection for the arch is evidenced in his works at Verona, the Palazzi Pompeii, Bevilacqua and Canossa.

Magrini discredits the story regarding Palladio's journey to Rome in order to undertake work upon St. Peter's, as is recorded by Paolo Gualdo.

According to Barichella, however, the high esteem in which Gualdo's biography is held would dispose one to reserve any opinion refuting this statement, which if true would prove the esteem in which our architect was held by Paul III. Unfortunately, according to Gualdo, Palladio on arriving in Rome found the Pope dead and the city in turmoil, and this must have been a great disappointment.

The biographers of Palladio give a good deal of space to this incident of the summons to Rome. There are no documents forthcoming to prove that Palladio remained in Vicenza during the days occupied in this journey to Rome, which is supposed to have taken place in November, I 549, in which month the death of Paul III. occurred.

An examination of the diary of expenses in connection with the Basilica at Vicenza, upon which work Magrini believes Palladio to have been engaged at this time, and which exists at the Museo at Vicenza, does not support his 
assertion that the Pope could not possibly have thought of Palladio at this time, the building of St. Peter's having been intrusted to Michael Angelo.

It is more than possible that, occupied in endless work and of great age, Michael Angelo felt the need of assistance. There is, therefore, every probability that Palladio, on account of his genius, had attracted the attention of the Pope, who had to think of a probable successor to the great architect, then in the seventy-fifth year of his age.

This great church would, but for this misfortune, have been a fine field for Palladio's genius, which, in conjunction with that of Michael Angelo, might have materially altered the completed design.

Palladio, Sansovino, and San Micheli stand out as the most prominent of the architects living at that time who could have been associated with the great Michael Angelo; consequently, there being no contrary proof, we see no reason to cast a doubt upon the statement regarding the summons to Rome by the Pope as chronicled by Paolo Gualdo. 


\section{CHAPTER III}

\section{PALLADIO AS AN ARCHITECT}

T OWEVER interesting the particulars of our master's 1 life may be, the great lessons which he taught are best found in the buildings which he designed. Although many of these were not carried out, or only partially so, we are fortunate in having his designs.

Many of these are to be found in "I quattro libri dell' Architettura," published in Venice in I570, a book which has passed through countless editions and has been translated into almost every European language. Palladio's own book, however, does not contain all his designs, but works by other authors contain a complete list, and in some instances include designs which are only reputed to be his. Of these the four volumes entitled "Les Batimens et les Desseins de André Palladio, recueillis et illustrés, par Octave Bertotti Scamozzi" are perhaps the most complete. Many editions of this were published, but perhaps the best was published in Vicenza in 1796 (in Italian and French). The four volumes contain over 200 plates, and are divided as follows: volume I contains the buildings erected at Vicenza; volumes 2 and 3 , buildings erected in the environs of Vicenza; volume 4, the churches which were erected at Venice, and other buildings in different parts of Italy. This latter volume also contains designs which have not been carried out. Amongst such a mass of material it has become rather difficult to make a selection of illustrations which 
shall be representative of his methods of design, especially having regard to the limitation of this work. It is hoped, however, that within the limit at our disposal, such a selection has been made as will enable the reader to form a good idea of our master's methods.

In regard to the buildings themselves, we have thought it best to divide them into :

(A) Public buildings and bridges.

(B) Town houses.

(C) Country houses.

(D) Churches.

By this method a better view can be obtained, in a more or less consecutive manner, of Palladio's attempts to solve similar problems in each type of building. Of the various methods and proportions adopted by our master, reference must be principally made to our notes on the buildings themselves.

A striking point about many of them lies in the fact that he was not slavishly bound by his own rules as to the proportions of the classical columns and their entablatures.

Like many another, he was an exemplar of the saying that a genius can be above rules, which are made for smaller men.

In his books, although Palladio refers in detail to the various parts of a building and their proportions, he has left no instructions as to the design and composition of structures as a whole.

In his use of the orders he was full of resource, as will be seen, and no particular method seems to have been peculiarly his own.

It has been held that he was specially in favour of obtaining size and dignity in his compositions by including two storeys of his façades within one order. This has been 
said to have influenced English architecture in contrast with the precepts of Vignola which were followed in France; but the fact is, that, as will be seen, Palladio employed both methods equally, while he was also fond of marking his ground storey with rusticated blocks of masonry, expressing his first floor (piano nobile) by an order, and his upper (or attic) storey with flat pilasters. It is to be observed that Palladio employed the attic storey, seldom used by other Italian masters, in lieu of a great crowning cornice.

According to many authorities, his Trissini Palace at Criccoli (see p. 77), and another for the same family at Vicenza, brought Palladio's fame to Venice at the time when Sansovino (1479-1570) was completing his illustrious career.

Our master's first work at Venice appears to have been the Conventa della Carità, described elsewhere. The entrance to the church is formed of an atrium of immense Corinthian columns, of which Sir Henry Wotton says: "Mine eye hath never beheld any columns more stately of stone or marble; for the bricks having been first formed in a circular mold, and then cut before their burning into four quarters or more, the sides afterwards join so closely, and the joints concentre so exactly, that the pillars appear one entire piece, showing how in truth we want rather art than stuff to satisfy our greatest fancy." This is quaintly put, but it serves to show, what we have already indicated, viz., that in spite of the mean materials with which Palladio was forced to execute his greatest designs, the design only impresses the beholder, which must put the composition on a very high plane. His style in general has been defined as a mean between the severe use of ancient forms and the licentious style of those who reject all rule whatever.

As remarked elsewhere, and as mentioned by Milizia 
and other authorities, many of the buildings attributed to Palladio cannot be by him, for the character and proportion vary so considerably. Milizia remarks very truly that it was sufficient for a fabric to possess any superiority for it to be instantly considered Palladio's work, for the vulgar are always desirous of honouring great men and consider this the means of doing it.

In regard to the plans of Palladio's buildings, speaking generally, it may be taken that they were suitable to the requirements of the Venetian nobility for whom they were erected. They were designed on classical lines, the kitchen and other household offices either being under the principal apartments, or in outside communication with them by covered colonnades.

The fact that the plans of Palladio's houses are not well suited to our present requirements cannot detract from their stateliness and convenience when considered in relation to the age in which they were erected, and the climate of Italy. The disposition and proportion of his apartments in regard to each other are often exceedingly happy and effective, such being placed symmetrically on either side of the vestibules and saloons.

In his country houses the Italian custom of having the farm offices in the same range of buildings with the mansion, and of raising the principal floor a considerable height above the ground was an effective arrangement, for it gave Palladio an opportunity of combining all in one composition, and obtaining dignity and breadth of grouping.

Some critics have found fault with the ultra magnificence and display which are observed in some of Palladio's façades; but here again we must remember for whom and with what purpose they were built. His clients were Venetian noblemen, eager to display their power and position by the erec- 
tion of grandiose buildings which Palladio provided in his spacious columned vestibules, grand staircases, galleries, libraries, and colonnades. Palladio eagerly, no doubt, yet rightly, availed himself of the opportunity of satisfying such noble requirements.

Reference has been already made to the use of the classical orders. Palladio's architecture was essentially columnar and not fenestral, and his entablatures were proportioned to the column with which they were associated; whereas his predecessor, Sansovino, occasionally employed an entablature disproportionate to the column, as at St. Mark's Library, in which windows are placed in a deep frieze. In addition to the methods already referred to, our master frequently used two orders of different scale in the same façade; one comprising the whole height of the building, and the smaller subordinate "order" being only one-half or two-thirds of the larger one. It has been pointed out that in every case except that of the façade of S. Giorgio Maggiore both orders rise from the same plinth level. This disposition of the double order had been employed by the Romans in the side porticoes of the temples. In his own work at the Palazzo del Capitanio and in the Basilica the difference in height between the two orders is as ten to sixteen and a half, while in the Palazzo Valmarana it is as ten is to twenty and a half.

Professor Cockerell rightly attributes a great part of the magnificence of Palladio's buildings to the employment of this principle.

Our master also had a great preference for a pediment to the central part of the principal façade, and says, "In all the houses which I have built in the country, and also in some (very few) of those which I have made in towns, I have always placed a pediment where the chief entrance is, 


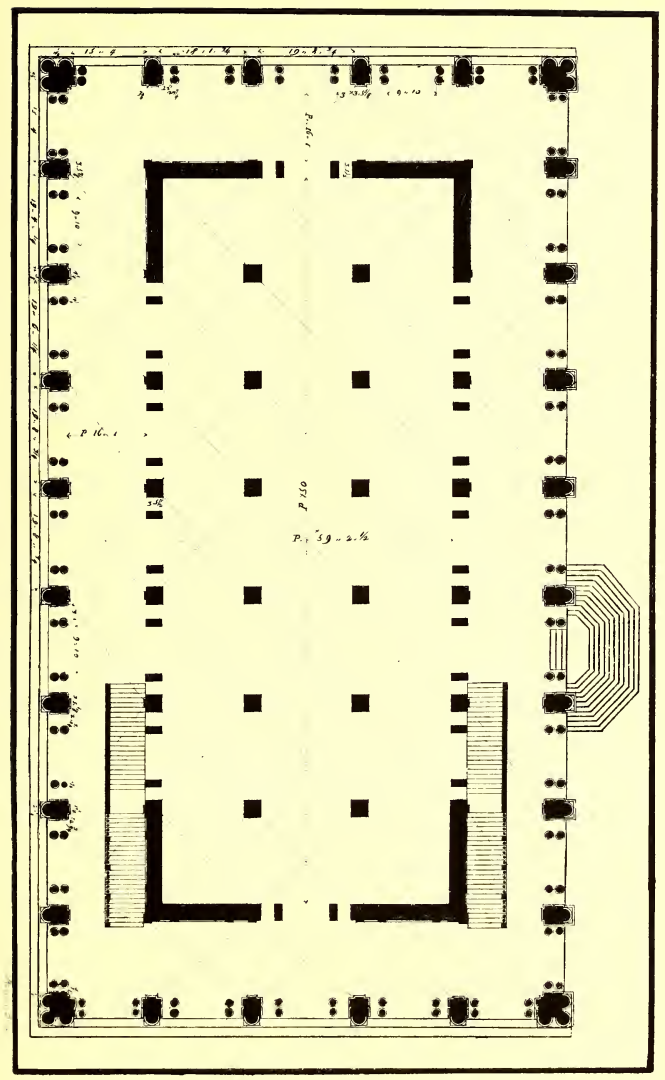

2. THE basilica (PAlazzo Della Ragione), Vicenza. PLAN. 

because it makes the principal entrance to the house more conspicuous, and contributes very much to the magnificence and grandeur of the building. This gives the entrance façade a great advantage over the others, as it must for that reason be made higher; besides, it is much more proper to put the arms of the owner there, and they are generally placed in the middle of the pediment."

The height of these pediments in our master's designs usually vary from one-fourth to one-sixth of the length of the horizontal cornice.

The columns were sometimes placed on pedestals, in order to give additional height, sometimes not so, the pedestals often having no plinths. The pedestals never seem to have been decorated with panels, sunk or raised, although this feature is so treated in Palladio's book. Fluting is generally omitted from the columns as designed by Palladio, and this was probably due to the fact that they were frequently formed of brick and stucco, materials which were unsuitable for fluting in long lengths.

Palladio's knowledge of the details of ancient Roman architecture was extraordinary, yet his inventive genius was considerable, and we seldom find that he repeated any of his designs. On the contrary, his façades abound with various dispositions of the orders, in addition to which he obtained effect and contrast by the judicious use of plain and rusticated walling and the use of arcades. His rustication is often excellent in design and scale, and gives considerable character to his buildings, not in an excessive way as at Florence, but as a set-off to his columns and their entablatures. In the design of his arcades and of entrance halls he appears to have preferred the larger order embracing two storeys, with small pilasters placed behind them to carry the floor of the upper gallery. In the arcades semicircular 
arches usually rest on piers in conjunction with a trabeated arrangement adopted from the ancient baths. A favourite arrangement (cf. the Basilica at Vicenza), however, was one in which he divided the interval between two piers in three parts by small piers or columns, with an arch only covering the central aperture, a combination which seems to have been copied from some colonnades at Diocletian's palace.

In the design of his doors, windows and niches, simplicity seems to have been in general sought after. Fewness in number and largeness in size was his aim. The openings were generally crowned by pediments, alternately angular and circular, but these were never broken-a rococo feature which he never indulged in. On these pedimented openings he occasionally placed reclining sculptured figures, probably copied from Sansovino or Michael Angelo.

Palladio also employed the semicircular Roman window divided into three lights.

In the entablature to his orders we find these to be generally unbroken, but happy effects are sometimes obtained, as at the Basilica, Vicenza, by projecting the columns beyond the main face of the wall and breaking the entablatures around these projections.

In the profile of mouldings he was specially careful ; the architraves and friezes were generally plain, the latter being sometimes pulvinated, and his cornices have the consoles and other ornaments carefully centred over each other.

Interior decoration seems to have been somewhat neglected by our master, owing no doubt to want of funds.

In regard to his church designs, instead of returning to the regulation forms of heathen temples, he was probably obliged for ecclesiastical reasons to keep to the Basilican or Lombard type of church, and his endeavour was to adapt the Roman orders to this type. The nave, being con- 


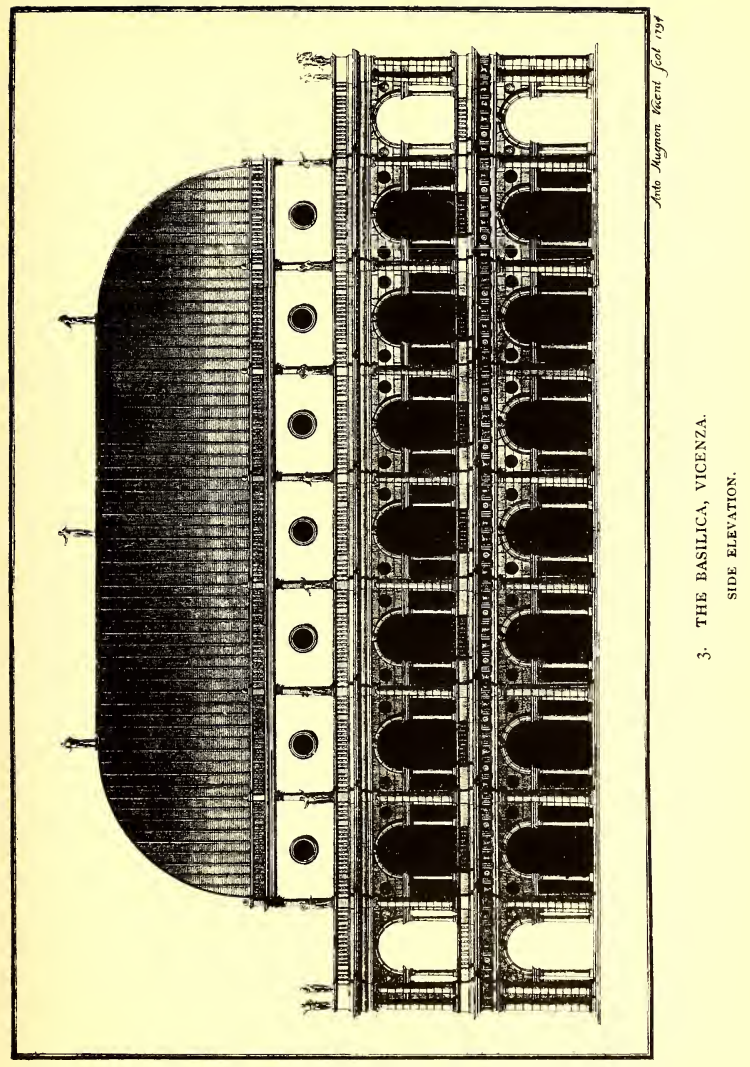



siderably higher than the side aisle, had to be treated independently of it, and instead of tiers of arches, he adopted a single order of columns placed on a plinth or on pedestals and supporting an entablature with pediment over. The aisles have their inclined roofs marked with half pediments. Types of these are shown in the illustrations.

In this chapter an endeavour has been made to sketch a few of the principal characteristics of our master's style and his chief methods of composition. Perhaps a better résumé of these has not been made than that given by the late $\mathrm{Mr}$. Wyatt Papworth. He says, that of all modern architects, Palladio seems to have had the best taste, the most correct ideas, and the greatest influence on his contemporaries. Some have had more boldness and genius, others more favourable opportunities of displaying their talents in grand and extensive works, but he has the peculiar glory of having mastered all the features and parts of architecture and of having produced edifices in which simplicity and beauty, symmetry and majesty are so combined, that they abundantly compensate for petty defects, and fulfil all the ends of architecture, by effecting that greatness of manner and unity of design which are more powerful means of producing grandeur than immensity of size or large masses unskilfully introduced.

These he had before him during his studies of Roman art, but by attention to their principle, practice and detail, he has formed a style that with few modifications is suited to all nations, and is probably such as the ancients themselves might have adopted. We shall well agree with Dr. Aldrich's observations, that if we examine his peculiar style, his large buildings have an air of grandeur that seems to be the result of volume, proportion and ornament, dictated by propriety. His villas speak themselves the 
retreats of nobility, veiled but not hid; if analogy between the human and material fabrics (much resorted to by writers on architecture) be allowable, perhaps we may not unfitly say that the general effect of Palladio's edifices is similar to that of personal dignity well dressed.

It is, after all, in the general proportion of his buildings and their various parts that our master pleases most.

The proportion of basement to the order which it supports and the attic over, of window to wall space, and the relation of column to entablature and the various parts of the design are excellent. 


\section{CHAPTER IV}

\section{PUBLIC BUILDINGS}

SOME of Palladio's town palaces may, on account of size and importance, be considered as public, yet we propose to treat in this chapter of buildings which were erected for a public purpose only, leaving however the consideration of churches to a later separate section.

Palladio deals with the public aspect of architecture in his third book, and divides the subject in the following manner:

I. Streets, Highways and Bridges.

2. Public places (Fora or Agora).

3. Basilicas, Arches of Triumph.

4. Theatres.

5. Palaestra.

In the main, he refers to the works of the ancients and quotes and illustrates largely from Vitruvius. His preface to this third book shows the lofty aspect he desired to inculcate in regard to architecture, as applied to public edifices, "wherein, because they consist of larger dimensions, and that they are beautify'd with more curious ornaments than private ones as serving for the use and conveniency of everybody, princes have a most ample field to show the world the greatness of their souls, and architects are furnished with the fairest opportunity to demonstrate their own abilities in excellent and surprising inventions." 
He then refers to the "fatigue and long watching" he has endured in drawing out the ancient examples, and "hopes that the lovers of antiquity may reap pleasure from the same, and the studious of architecture receive much benefit; especially seeing that much more is learnt in a little time from good examples or originals, by measuring of them and by seeing entire edifices with all their parts described on a little piece of paper, than from words," etc. This forms a very admirable exposition of what is known to us as the knowledge-through-the-eye process, and is worth quoting here.

To the streets and highways designed by himself, Palladio does not refer, but explains their construction and gives illustrations. He also refers to some ancient roads, such as the Flaminian, Appian, Aurelian and other wellknown Roman highways.

In regard to BRIDGEs, he says that they should be "convenient, beautiful and durable," a recipe in which municipal institutions of our own time would hardly appear to believe.

WoODEn BRIDGES.-He then refers to some ancient wooden bridges, and the bridge made by Caesar over the Rhine, and described in the fourth book of his "Commentaries." He refers to the fact that he shows the design"which I imagined in my youth when I first read these commentaries." He also says he utilized this design for a "bridge over the Bacchiglione without Vicenza." The reader is referred to Caesar's description, and to Palladio's reconstruction from it.

The Bridge on the Cismone.-This was erected by 
Palladio, and is an example of one having no supports in the bed of the river, which is a hundred feet wide at this point. This was rendered necessary by the swiftness of the stream, and the force of the timber floated down by it, which damaged the posts, whereby Conte Giacomo Angarano was under the necessity of renewing a previously existing bridge every year. The construction is that of a queen-post truss used in modern buildings for spans, between thirty and forty feet in length. Three other methods are then shown by Palladio, one of which is an extension of the above principle, and the other two are varieties of an arched type.

The Bridge at Bassano-a place at the foot of the Alps separating Italy from Germany. Here Palladio designed a more elaborate wooden bridge. The stream at this point was swift and 180 feet wide. This he divided into five spans of about 35 feet each, by means of rows of piles, eight in each row, 30 feet long and 18 inches square, these being at such a distance apart that the bridge was 26 feet wide. These posts supported joists laid crossways, while circular posts as Doric columns support a simple roof, which made the bridge into a covered way.

This was destroyed in 1748 , repaired by Ferracino, again destroyed by the French in 1813 , and rebuilt by Casarotti. There are two more designs in wood, one similar to that over the Cismone; the other is considered by Barichella to contain the elements of the so-called American bridges, which are considered an absolutely modern invention, and are so largely used in these days.

Stone Bridges.-Palladio discourses of stone bridges in general, in which he mentions four special points, viz., the abutments at the banks, the piers in the river, the arches 
and the pavement. He considers the piers should be of an even number, "as well because we see that nature has produced from this number all those things which, consisting of more than one part, are to bear any weight, as the feet of men and all other animals may convince us."

Such an arrangement is also to be preferred because it leaves the middle of the river free from obstruction, where the current is naturally most rapid, and it might be added in which boats would naturally be.

The front of the lower portion of the piers, known to modern engineers as "starlings" or "spurs," i.e., the side that faces the stream are to be made angular, in order that they may divide or break the water, and prevent floating matter from lodging against them.

Palladio refers to many ancient bridges which were still in existence at the time; notably those over the Tiber at Rome, the Elian bridge, built by the Emperor Elius Adrianus; the Fabrician bridge or "Ponto quattro capi;" the Cestian bridge (or bridge of St. Bartholomew), and the Senators' bridge, all of which existed. There were remains of others also as the Sublician (also Lepidan), the Janiculan (now Ponte Sisto) and many others. Reference is also made to the bridge over the Danube in Transylvania, destroyed by Hadrian, to prevent the incursions of the barbarians. Special prominence is given to the bridge built at Ariminum, probably by Augustus Caesar. This, which he illustrates, is a five-arched semicircular type, the two arches nearest the banks being 20 feet in span as against 25 feet given to the three central spans.

Bridges designed by Palladio.-The bridge over the Bacchiglione at Vicenza was added to by Palladio, as he mentions that part of it was ancient. It is a three-arched 
type; the side arches being $22 \frac{1}{2}$ feet in span, and the central 30 feet. The bridge is 24 feet wide.

The Rialto Bridge at Venice.-Curiously enough Palladio does not specifically mention the city in which this design was to be built, but it is evident it was intended for the Rialto bridge. It was unfortunately not carried out, the present bridge being erected in I588-I 59 I from the designs of Antonio da Ponte. It is to be observed how Palladio, with that good sense which he seems to have always possessed, so often made a virtue out of necessity. In this design he refers to the fact that " the bridge was to be built just at the very spot where the merchants come together to negotiate and treat of their affairs, wherefore he says, as well to preserve the grandeur and dignity of the said city as very considerably to increase the revenues of the same, I designed the bridge so broad, as to make three streets upon it; that in the middle large and fine, and the other two on the sides somewhat less." These streets were to be lined with shops. Thus Palladio produced a scheme which probably gained in dignity and importance by his intention of providing an adequate return to the merchants of Venice for their outlay. The bridge over the Retrone at Vicenza is called by Palladio an ancient bridge, and resembles the example over the Bacchiglione. He also refers to four others of the same character at Padua.

Public Places (Fora or Agora).-In the second division of his book Palladio refers to the squares, markets and open places of a city, and of the edifices which ought to be built around them:-such as the Prince's or Ruler's Palace, the Exchequer, Prisons, Senate and Council-house and Basilica (or Courts of Justice). 
He gives some useful rules as to the proportion and height of buildings in relation to open spaces, a subject somewhat neglected nowadays; and he also adverts to the necessity of porticoes to protect people from the elements.

He also refers to the Agora of the Greeks, the Fora of the Romans and the Palaestra or places of public exercise, and the ancient basilicas or courts of justice, giving designs for restorations of these after Vitruvius and others.

In a note on the basilicas or courts of justice, he mentions the fact that whereas the ancient basilicas were level with the ground, those of his time were over arches, in which were placed shops and prisons, and that while ancient basilicas had inside porticoes, those of his day had external ones or none at all.

The Basilica (Palazzo della Ragione) at Vicenza. - These arcades surrounding the three sides of the Gothic Consiglio, or Town Hall, are probably the most important of Palladio's works, and a glance at the previous history of this building may not be out of place. From researches made, it appears to have been of considerable importance in the middle ages. It then consisted of two floors, the upper one divided into two; one portion being a chapel, dedicated to St. Vicenzo, and the other forming a justice hall, while the lower floor was used as a prison.

In 1222 Lorenzo Strazza added a hall, which he built over five arches, as a meeting place for the Vicentine council of 400 . This hall, two centuries later was damaged by fire, and restoration or rebuilding became necessary. Then we read of the whole being transformed into one grand hall, between A.D. I444 and I477. In a few years two loggie (covered arcades) were added one above the other in the Gothic style, but shortly afterwards this work proved to be 


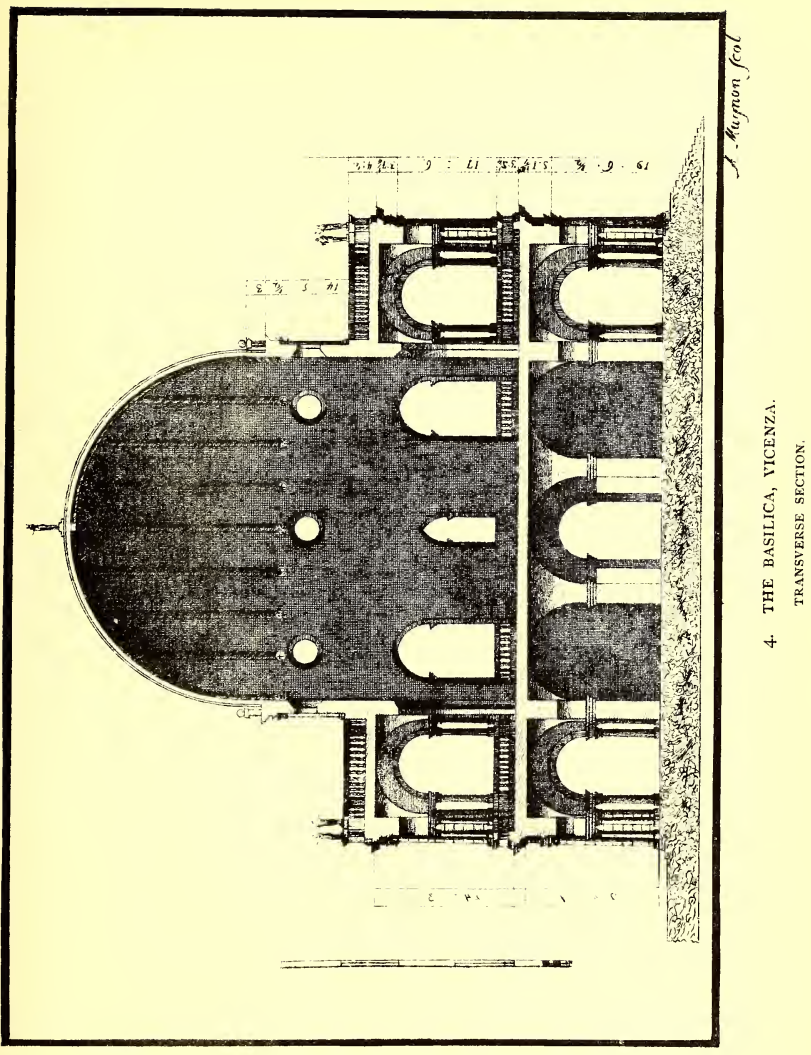



untrustworthy; the foundations giving way. It now became necessary to seek the aid of architects, and Riccio was engaged upon it in 1496, and Spaventa in 1498, both of them being in the service of the republic of Vicenza. Sansovino was consulted in 1538 , Serlio in 1539 and Giulio Romano in 1542 . Finally designs were submitted by the various architects, by desire of the Council, and these were so varied in style, that weary of the time lost, and of the controversy excited by such a competition, these designs were submitted by them to the vote and to public opinion. Of the many sent in, three only were chosen, one each by Spaventa, Giulio Romano and Palladio, with the result that the latter's design was finally chosen by ninety-nine votes against seventeen. (Arnaldi, i. chap. I3).

This is the design as executed, and it was commenced in 1550 and completed in I6I4. It was constructed in stone brought from Piovene, and this stone has weathered in a remarkable manner and gives to the building a beauty, which Palladio's stucco designs do not possess and will never attain. Much information about this important building is to be found in Magrini, "Il Palazzo della Ragione in Vicenza," Vicenza, Burato, 1875; also in “Des Basiliques anciennes, et en particulier de celle de Vicence. Dissertation du Conte Enée Arnaldi. Vicence, I76I " (see Plates 2, 3, 4, 5, 6, 7).

It is curious that Palladio says very little about the Basilica himself, but what he does say is in his Third Book, and is by no means modest. "There is another of them in Vicenza, of which alone I have given the draughts, because the porticoes around it are my own invention; and this I make no doubt, but that this edifice may be compared to the ancient Fabricks, and to be reckoned among the noblest and most beautiful buildings erected since the time of the 
ancients; as well on account of its largeness and ornament as of its matter, which is all hewn stone, extremely hard, join'd and bound together with the utmost care."

The hall around which the arcades are arranged is I 7 I feet long by 68 feet wide (Plate 2). It has a semicircular roof of lead, hipped at each end. The ground storey supports an upper one by means of arches; the upper storey to the roof being about 70 feet. By referring to the plan we see at once that the width of the arcade bays is determined by that of the piers of the Gothic hall which they surround, these piers dividing the interior of the ground storey into seven compartments in length and three in width. With these measurements (height and width), which could not be departed from, it is easy to see that Palladio had to decide on a design controlled and influenced by these data. He marked each storey by an order, the Doric to the ground storey and the Ionic to the upper one (see Plates 3 and 6); these being formed as half columns, backing on to a wall of considerable thickness, and their entablature returned back to this wall at each column, thus giving a vertical expression and preventing the squat proportion which would have resulted had the cornices been continued round the façade without a break. The centre of the inter-columniations had to correspond with those of the seven existing arches, forming the length of the hall itself. Furthermore, the height of any arches on the façade had to be considerably less than those of the hall proper, because the entablature of the order occupied some depth and the arcade had to be beneath this (see Plate 4). A statue crowns the balustrade over each pair of columns, and thus an unusual and difficult proportion of bay was cleverly handled by our master. It is perhaps in the design of the space between the principal columns that the beauty and originality of this 


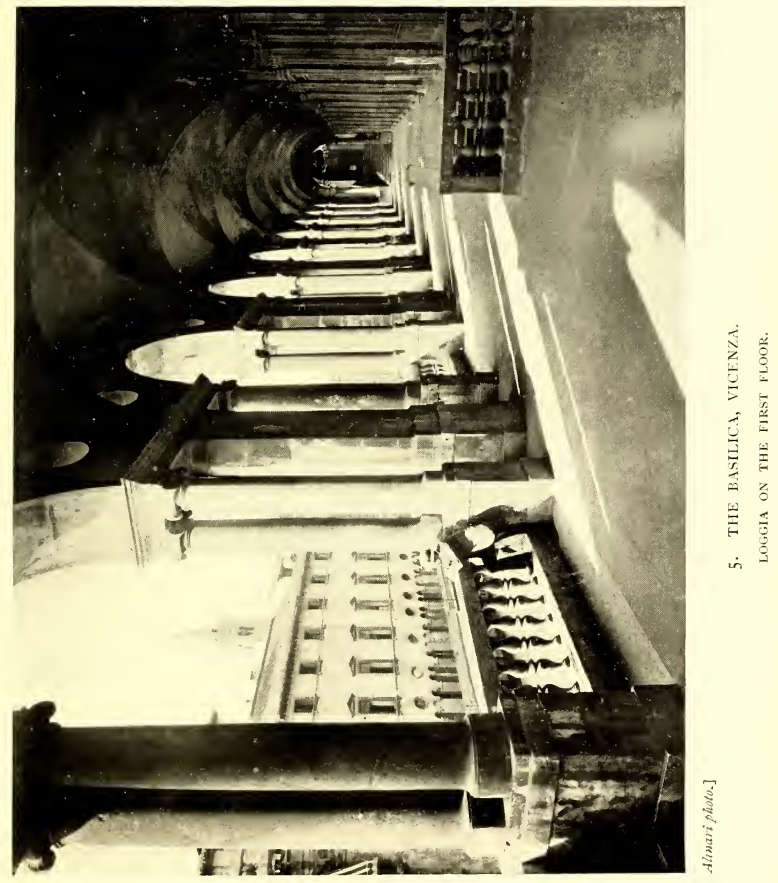





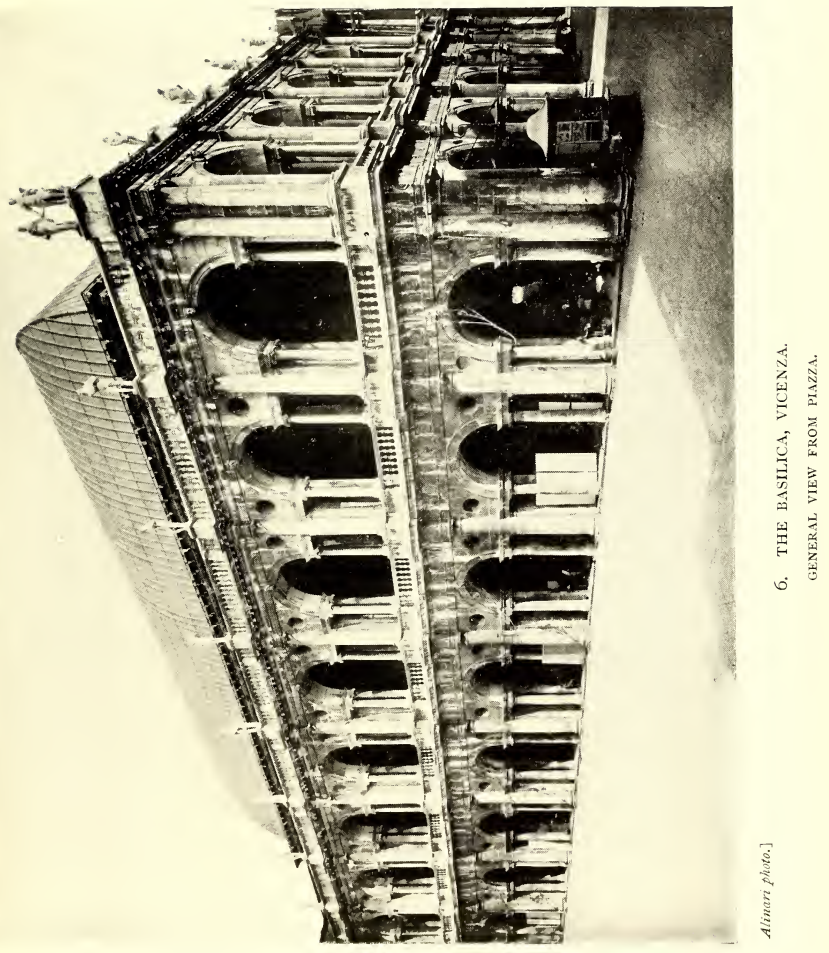





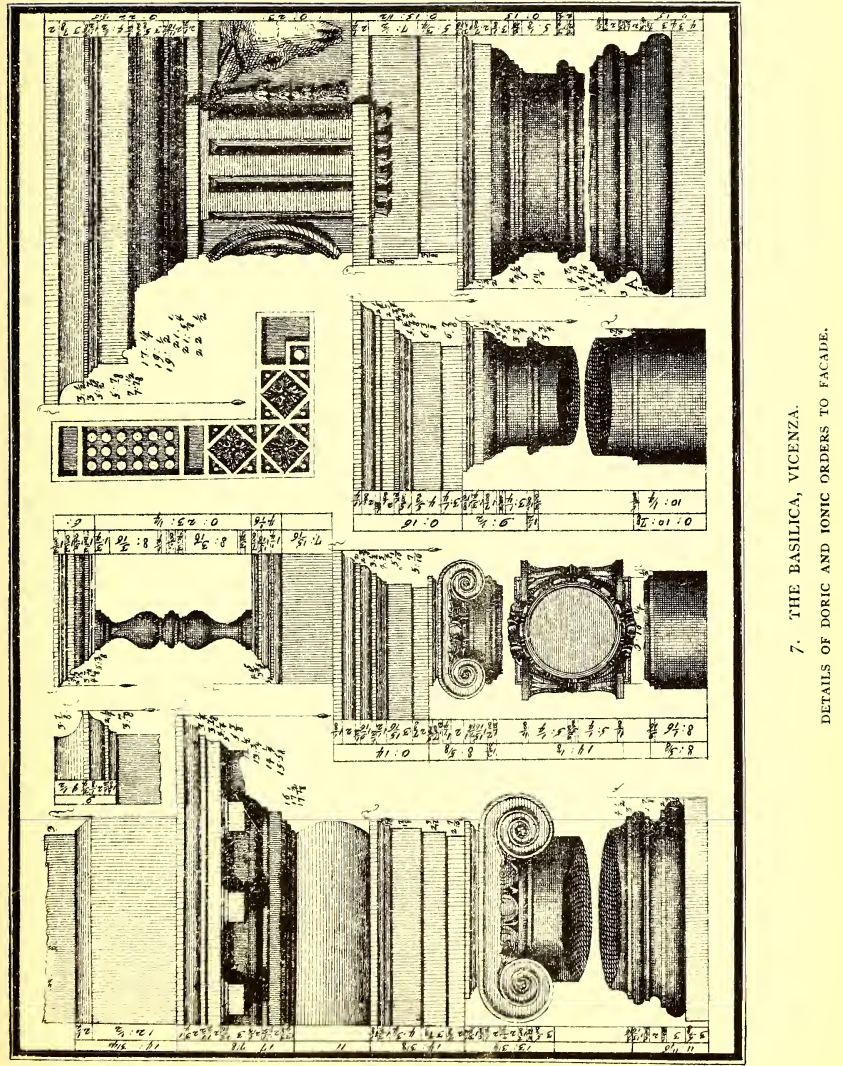



building are found. By referring to the illustration (Plate 3), it will be seen that a space approximating a square is contained between the main columns as vertical lines and the base line of these columns and the underside of their entablatures as horizontal bounding lines. It is particularly in his treatment of these that Palladio has shown his skill and has produced a motif which to this day is known by his name. He has filled in this square space with four columns, shown in Plates 5 and 6 (only two showing in elevation) placed in pairs, about 3 feet 6 inches from the main piers, these supporting a cornice from which springs a semicircular arch. In the spandrils are circular openings. Thus, forced by rigid conditions, did Palladio produce a masterpiece.

It has been pointed out that Peruzzi had used this same motif before in the Palazzo Linotta, Rome, but it was left to our master to give it his name for all time. The treatment of the angles of this building also shows the master hand. Here he was without any restrictions as to width, and he has decreased this by placing the coupled secondary columns nearer to the piers and by doubling the main columns at the angles (Plate 2); or rather by placing an extra angular three-quarter column which shows on each face. This diminution of width of bay and the doubling of the columns give an appearance of strength to the angles of the façade which is very pleasing. It is the same endeavour as is seen in the angles of the Parthenon and other Greek buildings, where the columns are brought nearer together than in the rest of the façade. The Basilica is such an important creation of Palladio that a few words as to its detailed proportion may not be out of place. The order to the lower storey is Doric, consisting of half columns about 2 feet 8 inches in diameter, attached to a 
wall about 4 feet 4 inches thick. The columns are 8 diameters in height (less 2 inches), and the entablature is slightly over a quarter of the column in height. The smaller Doric free-standing columns to this storey have the same proportion as the larger, but they are provided with a circular base, no doubt with the intention of preventing inconvenience to people passing either in or out. These small columns have a cornice, in height about one-eighth that of the columns, of the type shown in the sheet of details (Plate 7). From this springs the semicircular arch. The upper storey is ornamented with a large and small Ionic order, both placed on the same continuous pedestal about a quarter of the height of the larger columns, these latter being 2 feet 3 inches in diameter, and $8 \frac{3}{4}$ diameters in height. Bertotti refers to the fact that Palladio has not here followed his own rules nor those of Vitruvius, who says, "that when the columns are placed over each other, the upper one should be a quarter less in diameter than the lower," whereas in this case it is only one-sixth. The height of the Ionic entablature is one inch more than one-fifth of the height of its column. The smaller Ionic free-standing columns of this order are $14 \frac{1}{2}$ inches in diameter and are 8 diameters in height. The capitals are of the Grecian type and have circular plinths as to the lower ones, their cornice being similar to that on the lower storey and about one-eighth of the column in height. The proportion of the height of the arched opening to its width is two to one (including the depth of the pedestal). The balustrade which crowns the façade has a height of one-fifth of the Ionic order, without including the pedestal.

This building must rank as Palladio's masterpiece, the peculiar charm it now possesses is also largely enhanced by the beautiful weathering of the stone. 


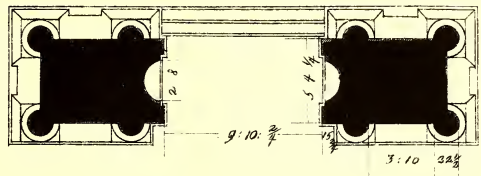

年
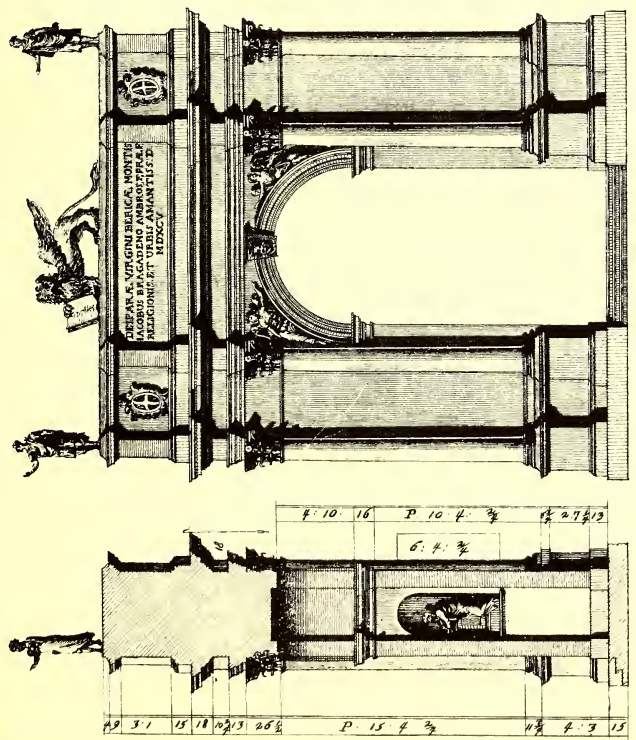



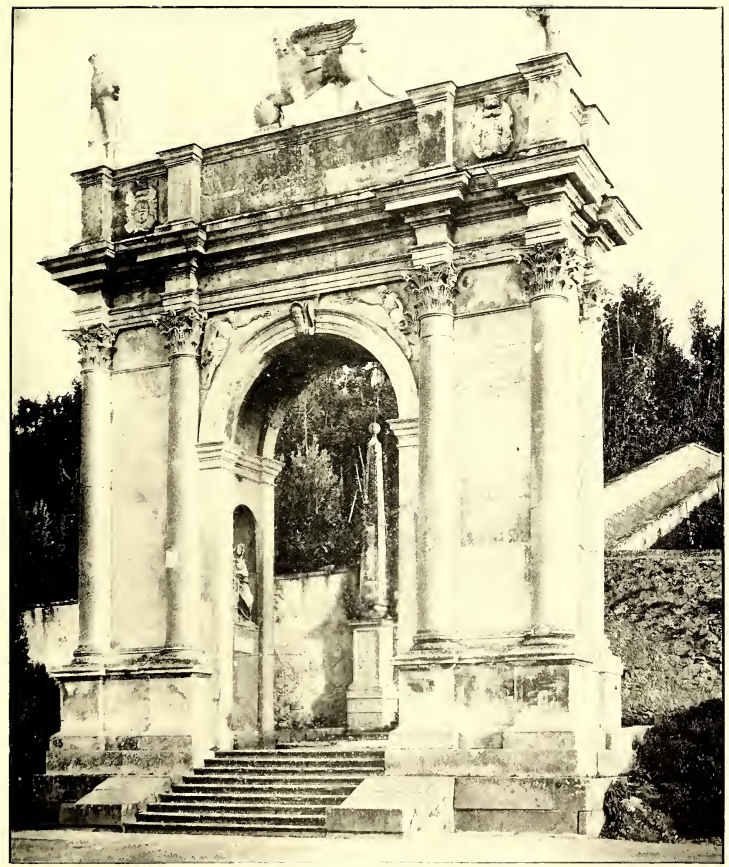

Alinari photo.]

9. ARCO DI TKIONFO, VICENZA. 

The Arco di Trionfo.-This arch (Plates 8 and 9), situated at the foot of the steps leading to the church of the Madonna del Monte Berico, near Vicenza, was erected in the year I595, i.e., fifteen years after Palladio's death. There is no authentic information as to whether it is our master's work or not. Bertotti endeavours to show that it differs considerably from the formulæ laid down in his book. The illustration will show the general proportions (Plate 9).

The Teatro Olimpico at Vicenza.-This is a good example of Palladio's profound knowledge of classical architecture and of the works of Vitruvius. In this building he was not in any way bound by precedent, as suggested by some who have only studied his work superficially. On the contrary, he well knew how to accommodate the principles of classic architecture and the precepts of its masters to the special circumstances of his own designs; modifying, as stated by Bertotti, " according to need, the proportions, forms and distribution of the parts, and wisely changing lengths and heights to his requirements."

Palladio's studies in Rome among the classic ruins, and also his excavations of the Berga Theatre at Vicenza, must have well equipped him for designing a theatre on classical lines. He also had made a special study of Vitruvius, and the elaborate directions laid down by that author, indicating how the ancients planned these particular buildings.

When, therefore, the Academy of Vicenza, which was founded in 1555 (and of which Palladio appears to have been one of the moving spirits), decided on constructing a building in which interesting and instructive plays of classic authors might be given, it was to Palladio, whom they regarded as a high authority on the subject, that they naturally turned. 
Palladio is known to have helped Signor Daniel Barbero in his "Commentaries on Vitruvius." Barbero also states in this work (published in Venice in I 556) how he visited the Roman remains and how Palladio and he had been able to get information from the Berga Theatre. At the commencement of the eighteenth century Bertotti mentions that there was a good deal of this still left, particularly the stage, but at the end of the century a modern building had been erected over the site. It is on record that our master had designed many temporary structures for the Academy, especially one which was erected in the Basilica itself in 1562 . The architect Serlio had also constructed a theatrical scene in wood for the town of Vicenza, which was built in the courtyard of the Palazzo Porto, as mentioned in his notes on Serlio's works by Jean Dominique Scamozzi (father of the better-known Vincenzo Scamozzi, the architect). These temporary erections seem to have given a considerable amount of dissatisfaction and trouble, and it was at length decided by the academicians to build a permanent theatre. The work was begun on the 23 rd May, I580, in Palladio's presence, but he was not destined to see its completion, for he died on the Igth of August of the same year. In gratitude for his work we are told that the Olympic Academy nominated his son Silla to superintend the work conceived and planned by his father. The theatre was not entirely completed till I584, and it was named "Olympic," after the Academy which founded it. It is curious that Palladio does not illustrate the theatre in his books, but Bertotti has published complete drawings, of which we illustrate the plan, and also two illustrations (Plates IO, I I, I2). The plan and general distribution leave no doubt that Palladio kept the form of the Roman theatre, as described by Vitruvius, in view, but that owing to the peculiar and restricted shape of 


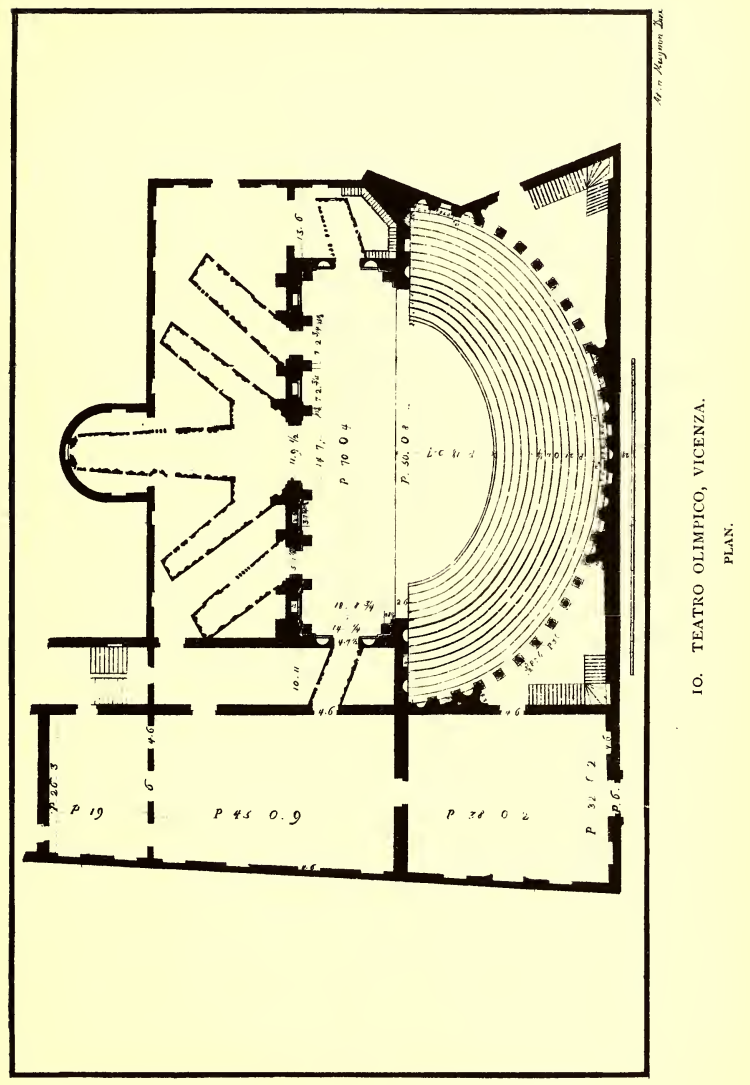



the site, variations had to be made; the most notable being the semi-elliptical auditorium, which takes the place of the semicircular plan of the Romans. Bertotti has been at some pains to inquire into the general principles of proportion adopted by our master, in which, owing to the novelty of the elliptical plan, he had to depart from the proportions of Vitruvius. His remarks are certainly ingenious and convincing, and warrant a detailed notice here.

As mentioned above, the shape of the site at his disposal may have induced many of the changes which were carried out. The building proper (Plate IO) occupies a site I 23 feet long by 75 feet wide. It will thus be seen that the space originally at Palladio's disposal does not include all that shown in the plan, but only the auditorium and the stage proper, as shown in the plates (Nos. I I and I2). The extra accommodation, including the three rooms to the left, and the portions behind the permanent scene, were acquired afterwards.

The diverging streets, shown in illustration No. I2, are built in perspective, and were designed and executed by the architect Scamozzi. We thus see that our master had a site a parallelogram in shape, and that out of this he wished to produce an auditorium, presumably as roomy as possible, and a stage. The elliptic form, or rather that produced by portions of three circles, was decided upon, thus producing a novel and pleasing result, and one probably most economical for the seating of an audience desirous of hearing and of seeing clearly. The exact setting out is described by Bertotti, and is shown in the annexed plan, No. Io. The ellipse is first set out as executed, and with half of the smaller diameter of this ellipse as a radius, a circle is described from the same centre. In this circle are drawn, at equal intervals, four equilateral triangles, touching the circum- 
ference of the circle. The side of one triangle determines the face of the scene, while the sides of the other three give the position of the wall dividing the audience, placed in rising tiers, from the sunk orchestra. The centres of the side openings in the scene are indicated approximately by the bases of the triangles carried through at these points. A line drawn parallel to the scene through the centre of the circle gives the position of the front of the raised stage (pulpitum). The width of the opening of this raised stage and of the orchestra is found by taking the distance between the two centres, from which the ellipse is described, and striking it off from the centre of the circle on each side.

The length of the scene itself is about $70 \mathrm{feet}$, which Bertotti imagines is found by adding the length of the orchestra, 50 feet 8 inches, to 18 feet 7 inches (the smaller semi-diameter of the ellipse), which equals 69 feet 3 inches, or as Palladio has it, 70 feet 4 inches. The height of the podium, or continued pedestal on which the columns of the scene rest, and which according to Vitruvius should be onetwelfth part of the diameter of the orchestra, was fixed by Palladio at 4 feet, which is one-fifteenth part of the larger diameter of the ellipse.

Scamozzi, in endeavouring to prove that Palladio kept to the rules of Vitruvius as much as possible, making these work in with an elliptical plan in place of the usual semicircular one, points out that the height (4 feet) is nearly equal to one-twelfth of the half of the larger and smaller diameter added together. The face of the scene, constructed in stone, is composed of two orders of Corinthian columns placed one over the other. Vitruvius gives the rule that the columns on the podium of the lower order should be a quarter of the diameter of the orchestra, and Palladio has made them 14 feet in height, or 8 inches less than a quarter of the 


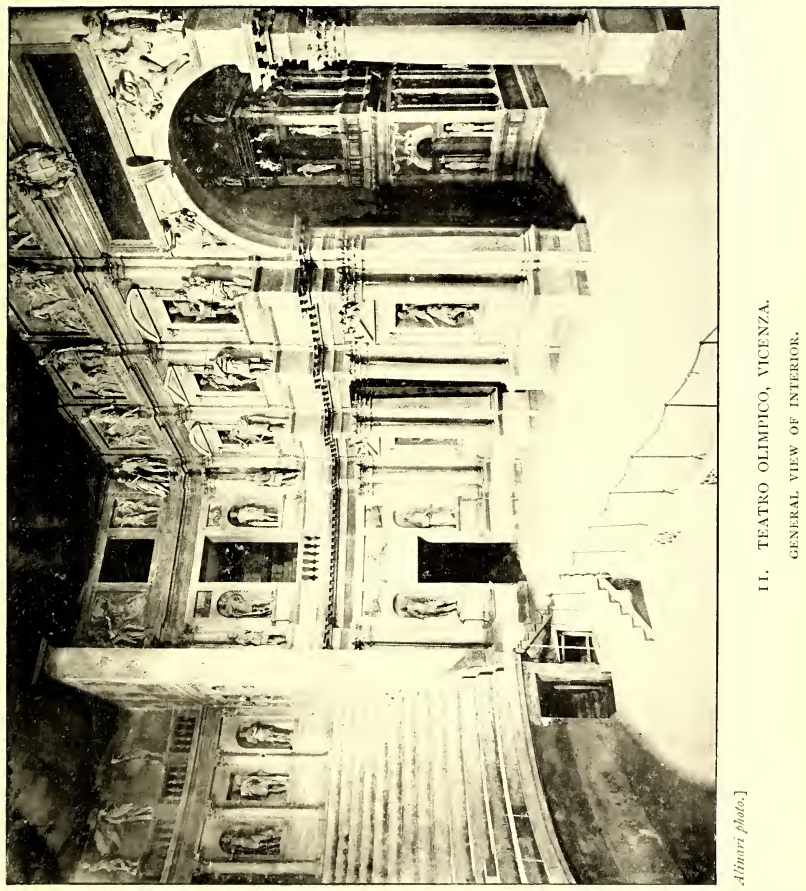



diameter. These columns are $9 \frac{1}{2}$ diameters in height. The upper order of the scene is also of the Corinthian type. The columns are I I feet 6 inches in height, and are of the same height as the lower ones, and their lower diameter is equal to that of upper diameter of the lower columns. The upper columns (see Plate I I) are not isolated like those below, but are semicircular in plan and attached to the wall. Their pedestals project over the lower columns and support statues, forming a very pleasing feature. Bertotti states the leaves of the capitals are of the olive, a leaf similar in treatment to the acanthus. Above the upper order of Corinthian halfcolumns is an attic storey about 8 feet 9 inches high, with small pilasters over the axes of the lower columns. In front are placed statues, while between them are square panels filled with sculptures representing the labours of Hercules, executed by well-known sculptors.

Between the columns of the ground and first storeys are placed niches occupied by statues and framed in with pilasters, entablature and pediments, triangular or segmental. The centre of the scene has a large open archway of semicircular form, springing from the cornice of the lower storey, and there are smaller square-headed doorways on either side ; formed under the entablature of the ground storey.

These openings, central and side, form entrances to the interior scene constructed as streets radiating therefrom. These streets are built in perspective, with buildings on either side (see Plate I2); the line of sight, or horizontal line, being halfway between the stage level and the upper tier of seats of the auditorium.

This construction in perspective was not designed by Palladio, but, as mentioned above, by the architect Scamozzi, as mentioned in the proceedings of the Academy and the history of Vicenza by Marzari, and also by Scamozzi him- 
self. This idea of perspective was introduced by the Renaissance architects.

The return walls of the scene, which are at right angles to it, are treated in a somewhat similar manner to the front (Plate I I). On the ground floor is placed a doorway centrally to each return, having on each side a semicircular-headed niche, above which are slightly sunk panels filled with bas-reliefs. The first floor has a central opening, protected by a balustrade instead of a doorway. As to the inclosing wall (or podium) of the auditorium, the rule of Vitruvius was that its height should be one-sixth part of the diameter of the orchestra, which in this case would be 9 feet 6 inches. In the case of an elliptical plan, however, Palladio had to depart from this, and Bertotti theorizes as usual on the subject, and gives his own ideas as follows: he finds that the longer diameter of the orchestra-namely, 58 feet-added to the shorter one of 43 feet, equals in total measurement roo feet; one-half of this equals 50 feet, one-sixth equals 8 feet 4 inches, and Palladio has approximately followed this; the wall surrounding the orchestra being about 8 feet 4 inches high. Above this inclosing wall, semi-elliptical on plan, are constructed the seats in thirteen rising tiers. The master was restricted here by the site, and his seats are therefore more cramped than they would otherwise have been. They are about $2 \mathrm{I}$ inches in width and $\mathrm{I}_{5} \frac{1}{2}$ inches in height. Above the top row of seats is placed a Corinthian colonnade, the columns being 15 inches in diameter and 12 feet 6 inches high. These are cleverly contrived to hide the irregularities of the site (Plates Io and II). The centre and wings are of engaged columns, having niches alternately square-headed and semicircular formed in their intercolumniation. In these niches are placed statues, as seen in the illustration. The remainder of the colonnade is formed of isolated columns, with seven 


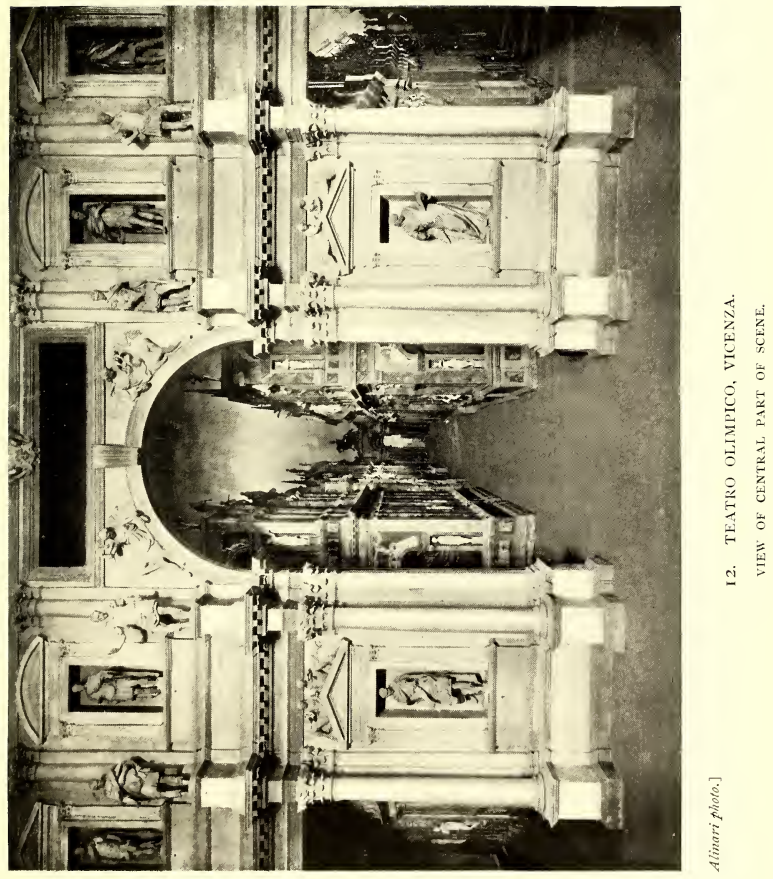





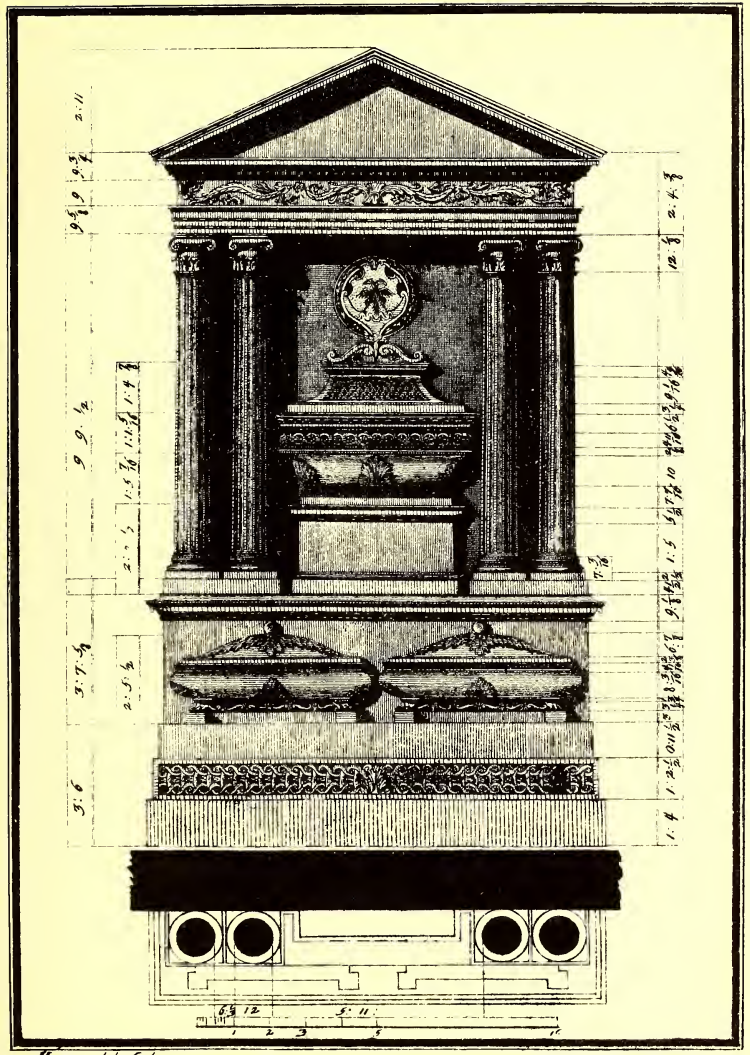

Fugnon delitint

13. MONUMENT to COUNT LEONARDO PORTO IN S. LORENZO, ViCENZA. 

intercolumniations to each division; these act as screens to the staircases formed in the angles of the building. Above the entablature of this colonnade is a balustrade, supporting statues vertically with the line of columns which were executed by Giacomo Casetti.

The height of the theatre from the level of the stage to the attic cornice is four-fifths (less 9 inches) of the diameter of the orchestra, viz. 40 feet. The ceiling is flat, and extends without interruption over auditorium and stage, allowing the voice to travel without hindrance. Both colonnades and porticoes would no doubt have been provided had space permitted.

The Theatre at Parma (I6I8) is attributed to him, but it appears to have been designed by G. Aleotti and completed by Bernini as stated by Milizia.

The Monument to Conte Leonardo Porto(Plates I 3 and 14).-This is in the Church of San Lorenzo at Vicenza, and is reputed to be by Palladio, although not mentioned nor illustrated by him. It consists of three tombs; the principal one containing the remains of Conte Leonardo Porto, and the two lower ones those of his two sons. The design consists of a basement or pedestal, on which rest four isolated Ionic columns, with wide central intercolumniation, in order to allow of the principal tomb being placed there. These columns support an entablature and triangular pediment. The capitals are unusual, having, beside the Ionic scroll, a single row of acanthus leaves round the necking (Plate I4).

Among other of Palladio's reputed designs which we can only briefly refer to are the following:

The Triumphal Arch at Venice, erected on the occasion 
of Henry III. entering as King of France (a design similar to that of Septimius Severus at Rome).

The first storey of the Palazzo Publico at Feltre (the second one was by another architect).

A Gateway at Bassano.

At Brescia he designed some of the ornamental detail for the Municipio (usually called the "loggia"); this was commenced by Bramante. An illustration is given of one of these (Plate I5). The loggia was erected by Formentone, of Brescia, in 1508 , on the ruins of the Temple of Vulcan; the "putti" frieze is by the architect Sansovino, and the window dressings are said to be by Palladio. If they are really his work, they indicate a much earlier type of detail than is usually associated with his name.

Piedmont.-The laying out of the ancient Royal Park.

Vicenza.-The Piazza Maggiore, I549. 


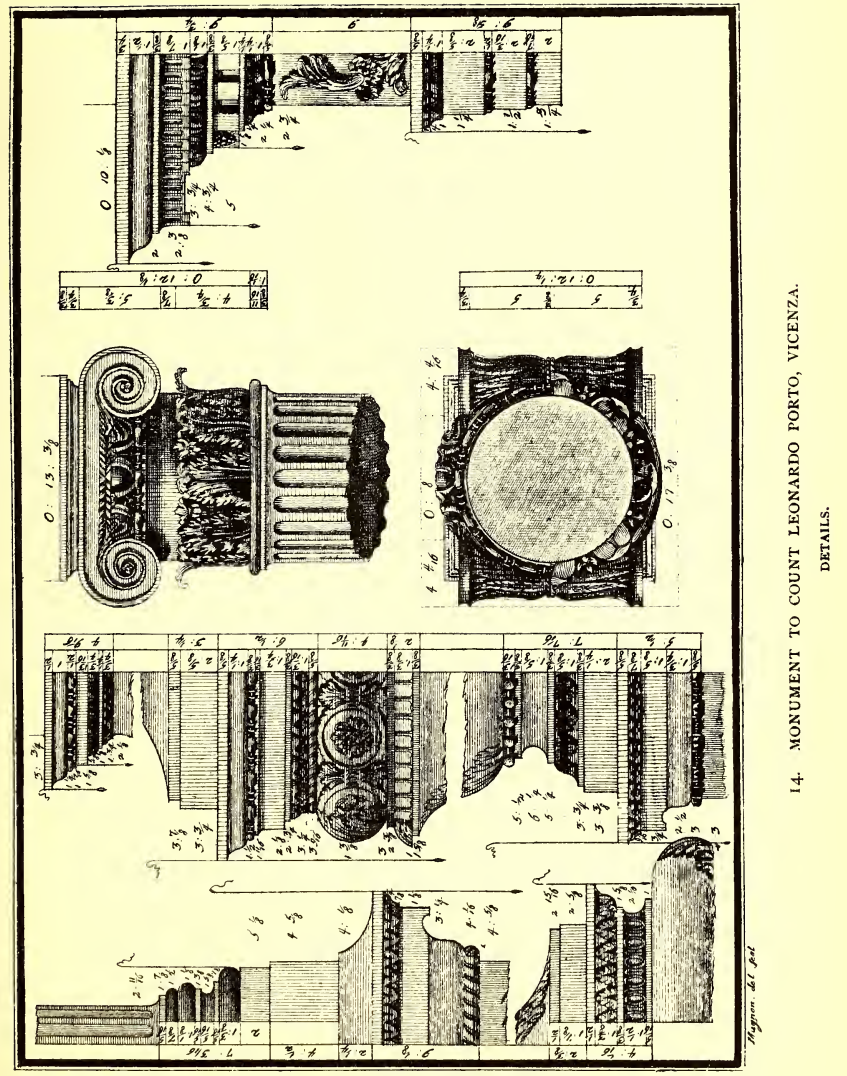





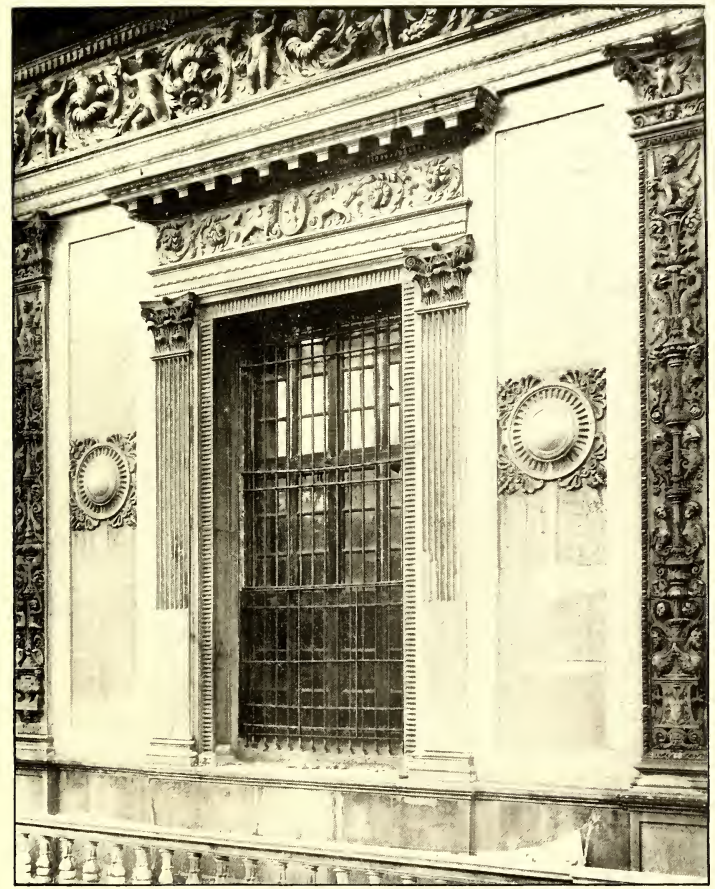

Alinari photo.]

15. TIIE PALAZZO MUNICIIALE, BRESCIA.

THE WINUOW DRFSSINGS ARE SAID TO LF BY PALLADO, 



\section{CHAPTER V}

\section{TOWN HOUSES}

SOME of Palladio's most important designs were the $\$$ palaces he erected in his native town of Vicenza. They were mostly built in brick faced with stucco, which has now fallen away from the brick background, and in consequence the designs, fine though they are in proportion and detail, suffer from having been executed in such mean materials. Our architect has been blamed for this by certain critics, who evidently consider that an architect should be responsible for the depth of his client's purse! We would rather rejoice that Palladio, in spite of the material at his command, should have been able to produce such excellent results.

In his second book (Chapter III) Palladio introduces the subject of town houses with some quaint remarks. $\mathrm{He}$ says: "I am sure that they who shall look upon the buildings I am going to give the draughts of in this book, and they who know how hard it is to introduce a new way, particularly in the art of building (in which everyone presumes to be knowing) will think me very happy that I have met with persons who were generous, judicious and reasonable enough to hear and approve my reasons, and afterwards to give over that old way of building, which is without any proportion or grace at all : and indeed I own it as a particular favour God has done me amongst many others to give me an opportunity of putting several things in 
practice which I had learnt by a very laborious examination and long study."

The Palazzo Chiericati (Plate 16).-The plan shows that a great gallery, or portico, extends the whole length of the principal front on the ground floor, and is carried up on the two wings to the first floor, the central portion of the upper floor being walled in and forming the hall. The front of this building has two orders, the Doric for the ground floor, the Ionic for the first floor, and is an example of a treatment which Palladio often favoured. This is to be remarked, because his name is generally associated with the treatment of an order embracing two storeys in height. This façade may be studied with advantage as an excellent example of our master's method.

In Leoni's edition of Palladio's “Architecture," this building is shown with the central Ionic order of the first floor as pilasters, instead of half columns, as shown in our Plate I6. This mistake appears in Leoni's edition of I715, and in all the subsequent editions of Palladio's works by this author.

It also occurs in the editions of the architect N. N. Most critics will agree that the substitution of pilasters for half columns would have deprived the façade of much of its interest. The proportions of the rooms follow out Palladio's methods as described in Book I., Chapter XXIII.

Another special feature of the façade is the continuous pedestal, or stylobate, upon which the lower order rests, forming a solid base or support to the whole structure. The Doric column itself is also of sturdier proportions than usually adopted by Palladio, being seven and a half diameters in height. This proportion was probably used because Palladio felt that as these free-standing columns supported 


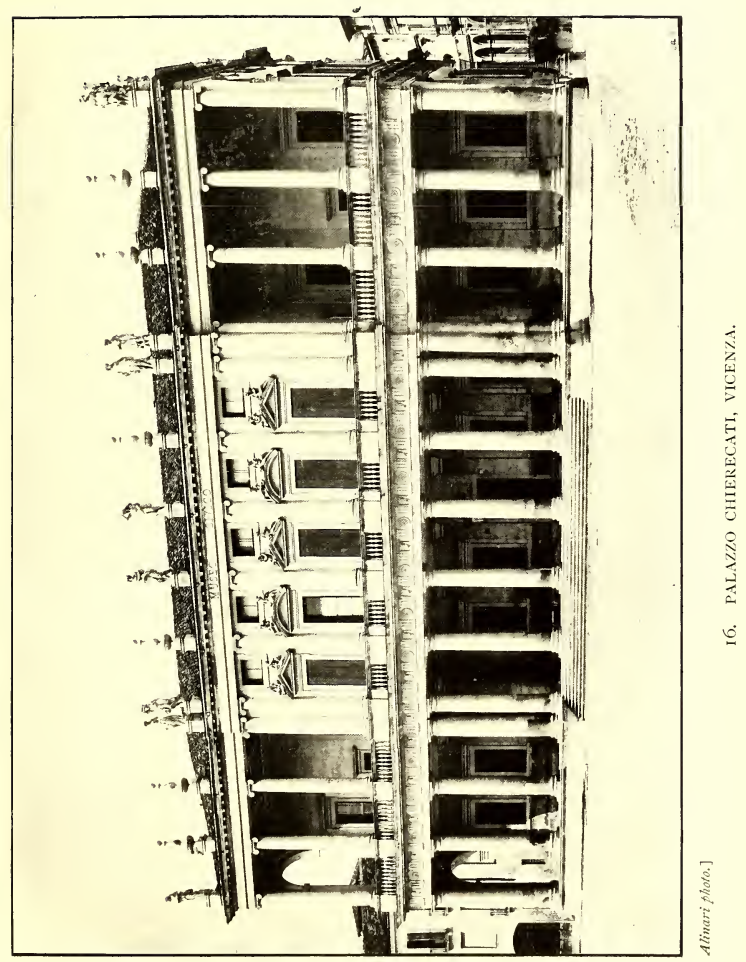



an upper storey-the central portion of which was solid-they would otherwise look too weak for the purpose. The intercolumniation is three diameters, or as Vitruvius calls it, diastyle. It is also to be noted that the windows and doors on this floor have a height of twice their width, whereas in the upper storey they are twice and one-eighth of their width in height, a difference giving a lighter and more graceful proportion to the upper windows. Such deviations from the master's own precepts are interesting as showing how he altered them to suit the circumstances of the case; in order to create an ensemble in which the various features were proportionate.

The upper storey is treated with the Ionic order, nine diameters in height, resting on pedestals which have no base. In comparing this building with Palladio's own rules one sees at once that he was no slavish adherent to them, but that when necessary he practised modifications which his good taste and better judgement demanded.

In Palladio's book none of the statues or vases are shown which are seen in the illustration as crowning the structure and carrying up the vertical lines of the columns. It is doubtful if these additions improve the design, certainly the attenuated vases have a very unpleasant effect. Although a large part of the building appears to have been erected during his lifetime, it was only finished a considerable time after his death, viz., towards 1700 . Bertotti says it was confided to a master mason who had neither knowledge of architecture nor the least idea of our master's taste or style. In consequence, we find in the portion finally constructed innovations out of character with the original work. These consist of circular instead of flat ceilings in compartments, also in a decorative treatment not originally intended. Bertotti, in conclusion, defends Palladio from certain re- 
proaches made against him by many critics, viz., that he had studied too much the magnificence and general proportions of his buildings, and had cared too little for the convenience of the persons who were to inhabit them. In dismissing the charge Bertotti thus refers to the methods of living, and to the customs of the century in which Palladio lived: "The men of these times only demanded in their houses a certain number of rooms, suitable to their needs, and these needs were not multiplied to infinity as they are in our time." O happy sixteenth-century architect ! to have existed before sanitation hindered magnificence by the exposure of drainpipes in our house fronts.

The Palazzo Thiene (Plate I7).-Situated near the market-place. This was one of Palladio's most important commissions, and, like so many of his designs, was only partly finished. In plan it consisted of a central square courtyard of 84 feet 6 inches, surrounded by a rusticated arcade, beyond which are the various rooms; the size of the whole site being I 90 feet by 176 feet.

Palladio's remarks regarding this building show him to have possessed common sense, for after mentioning the fact that the building is in the heart of the town, he says, "I thought it was very proper to leave the ground floor for shops on that side which fronts the market; the architect being obliged to have some regard for the advantage of those that are at the expense of the building." Thus does history repeat itself! In the classic days of Rome, in the Renaissance, and in modern times, the same commercial necessities have had to be provided for. In this case a mezzanine, or half storey, is placed over the shops for the use of the shopkeeper. The façade shows another method, and certainly not the least successful. A rusticated lower 

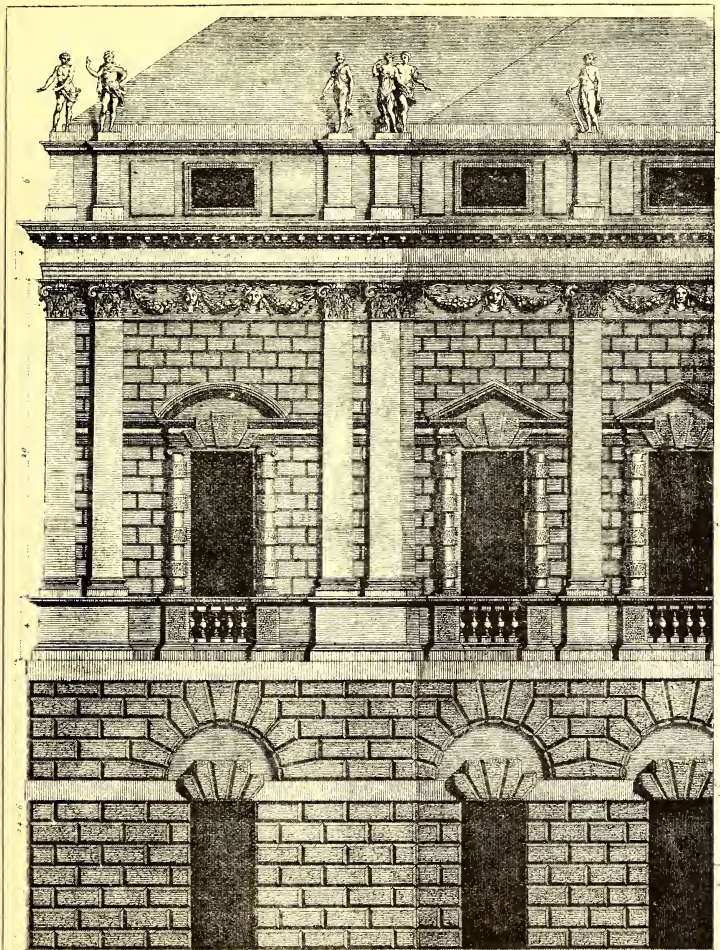

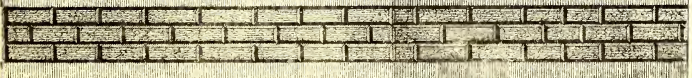

17. PALAZZO THIENE, VICENZA.

DETAL OF PORTION OF FACADE, 

storey with flat arched windows, surmounted by semicircular arches, supports the first floor, ornamented with composite pilasters on pedestals, and above this order is placed an attic. The windows to the first floor have small three-quarter Ionic columns with entablature and pediments. This is an excellent composition, the reserved use of the order for one storey only being very happy. These first-floor windows have rusticated shafts resting on pedestals, between which are placed balusters; a somewhat unusual composition, and probably designed by Palladio in order to lead by an intermediate stage from the masculine treatment of the basement to the delicate Corinthian pilaster stage. Leoni makes another mistake in rusticating the pedestals of these Ionic columns, which are in reality plain. In Palladio's original designs the pedestals have bases, whereas in execution they are without them, as in Bertotti's drawing. In Leoni's drawing the main entablature is shown at about one-fifth of the height of the column, which is Palladio's usual proportion, whereas in execution it has been increased to onefourth its height; our architect evidently taking account of the narrowness of the streets and the consequent foreshortening of the upper mouldings. This is a measure of necessity which had been previously insisted upon by Vitruvius in his Book III., Chapter III. The courtyard is equally fortunate, a similar treatment being adopted, except that the necessary openings are left for the arcading between the piers. The attic here has also small windows lighting the rooms of the upper storey. In regard to this building, Bertotti has found many discrepancies of which other authors have been guilty in their measurements and drawings. $\mathrm{He}$ also refers to the fact that the completed portion was undoubtedly erected during Palladio's lifetime, and that his published drawings are not as carried out, premising that 
Palladio was probably too busy to correct his drawings. $\mathrm{He}$ also gives his own ideas of what the complete scheme would have been in regard to plan, elevation and section, and rightly reprimands Leoni, who in his edition of Palladio's works, published in London in I7 I5, has shown attics on the outer façade, as well as on that to the courtyard, which do not exist in the executed portion. Such a mistake is unpardonable, and Bertotti is justified in referring to it in strong terms. Bertotti rightly eulogizes this building, and we can agree with him when he says, à propos of his restorations of the designs, "The striking magnificence of the exterior and the interior, the solidity of the ground storey, the elegance of the second, the continuity of the entablature, the strength of the arcades and of the pilasters which ornament the courtyard façade, the noble and judicious distribution of the apartments, make up a scheme which, if executed in its entirety, would have made an ornament worthy of the country of Palladio." According to our master, the finished portion was adorned with sculpture by Alessandro Vittoria, Bartolomeo Ridolfi, and with paintings by Anselmo Canera and Bernardino India, both the latter being of Verona.

The Palazzo Valmarana.-This is one of the best known of Palladio's works, and the plan and illustration will explain the general distribution and treatment to the reader (Plates 18 and 19 ).

Our author in his book says, that the "Conti Valmarana built according to the following designs, not only for their own honour and convenience, but also for the ornament and glory of their country." Truly a noble and patriotic sentiment. Would there were many such men nowadays in this great British Empire! The plan shows that the house 


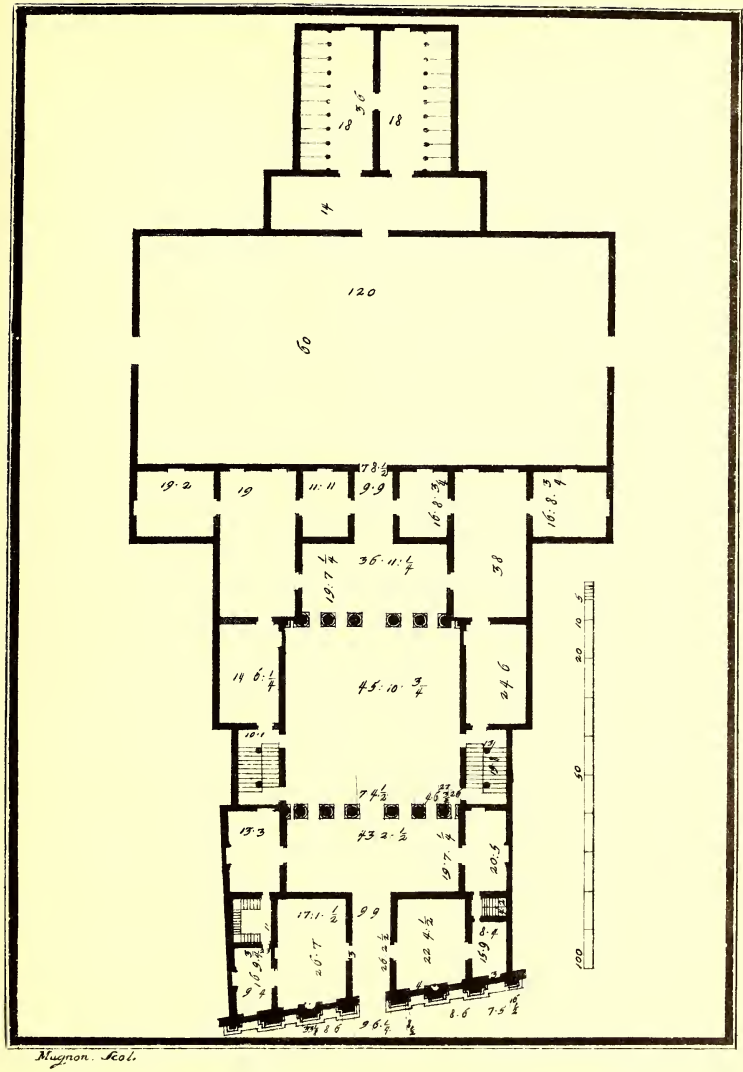

18. PALAZZO VALMARANA, VICENZA.

PLAN, 



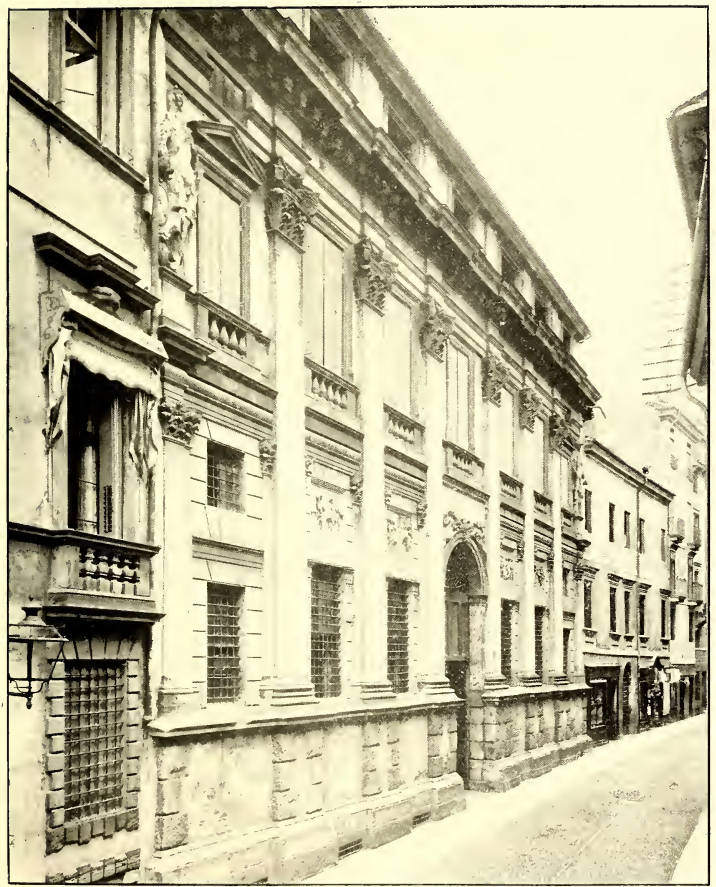

Alinari fhoto. ]

19. PALAZZO VALMARANA, VICENZA. 

is divided into two parts by a central court, and behind is shown a large garden, I 20 feet by 68 feet 6 inches wide. The stables are also placed in rear of the site.

The ground-floor apartments are vaulted ("arch'd" as Palladio calls them), and the upper ones ceiled at a height equal to their breadth. It is curious to observe that in Leoni's edition the site of this building is shown as rectangular on plan, whereas in reality-as shown in Bertotti Scamozzi's drawing-the front wall is not at right angles to the side walls. There were two ways only of treating this façade, viz., either that of making a front wall at right angles to the side walls, in which case it would have to be set back from the general line of the other buildings in the street, or else as Palladio arranged it, of making it line up with the general building frontage, allowance being made for the difference of shape in the front rooms. In choosing the latter arrangement, Palladio not only showed his good taste, but left it as a legacy for architects of all times. Many modern buildings have been spoilt by neglecting to adopt this principle in dealing with awkwardly shaped sites. The method of setting back the façade in order to make the rooms square is very unsatisfactory, and has only to be seen to be at once condemned. Thus from our predecessors dowe learn principles equally applicable in our own day. The façade (Plate 19) of the Valmarana Palace has been the subject of much criticism. It shows another of Palladio's treatments, having an order of Composite pilasters embracing two storeys in height and having an attic storey over them. At the extremities the main order embraces three storeys. Only the front block of this important design has been executed. The façade above the base is in brick and stucco. The great pilasters are of the Composite order, and have a height of ten and a quarter times their diameter. The main entab- 
lature is one-fifth the height of the column, and the order rests upon projecting rusticated pedestals one quarter of the height of the pilasters. The secondary order, of the Corinthian type, which marks the ground floor, rests upon the same pedestal as the larger order, an arrangement which many critics have denounced.

This order consists mainly of half pilasters with entablature one-fifth of their height backed against the main order, and is not a happy arrangement. The entablature to this order is one-fifth of the height of the pilaster, and is broken at each intercolumniation against the main pilasters. Above the main entablature is an attic, the height of which is one quarter that of the pilasters. The windows to the principal storeys have a height of twice their width, the upper ones having balconies of small projection. Palladio shows statues surmounting the flat pilasters of this order, but by referring to the view it will be seen that they have not been executed. The interior colonnade is of the Ionic order, $8 \frac{1}{3}$ diameters in height. As showing the variety which Palladio could introduce when he wished, it is interesting to find that the central intercolumniation of this colonnade is $3 \frac{1}{4}$ diameters, the intermediate ones 2 diameters, and that of the angle columns I diameter. The width of the central one is required for the passage of carriages. Critics are divided in regard to the Valmarana Palace, the main point in dispute being the treatment of the extremities of the façade. By reference to the illustrations, it will be seen that the main pilasters are not continuous and do not terminate the façade in a manner which might be expected, the secondary order being doubled instead and made to support statues above its cornice. As a principle of design this, in the opinion of some, does not appear correct, the length of the façade being thereby apparently diminished and the framing of the whole 


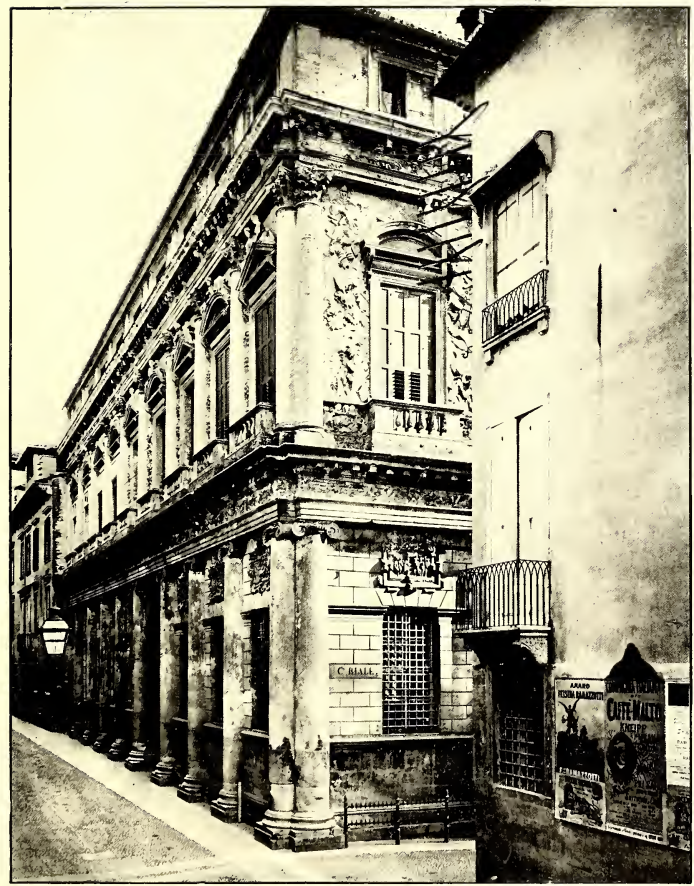

Alinari photo.]

20. PALAZZO BARBARANO, VICENZA. 

design unpleasantly affected. It is unfortunate that the house is unfinished, but Bertotti's views may be accepted without hesitation when he says that "it would have been a chef-d'curve of beauty and magnificence, as much for its extent as by the regularity of its distribution and the elegance of its ornamentation."

House for Signor Guioglio Capra.-Palladio describes this house as already commenced, being situated in the principal street of Vicenza. It was one of the smaller designs, having a frontage of about 50 feet, and has, as is usual, an internal courtyard. The façade has an astylar rusticated basement (ground storey) supporting an upper storey, ornamented with Corinthian pilasters and entablature, the latter being mutilated by the insertion of windows.

The Palazzo Barbarano (Plate 20). -This is interesting in many ways, because Palladio shows his original design and also that which was actually carried out. In plan, this has an entrance leading to a large columned hall beyond which is an open court. As to the façade, each storey has its own order, whereas in the original design one Corinthian order of semi-columns resting on a podium was carried through two storeys.

There is no doubt that the second or executed design is immeasurably superior. On the ground floor the wall space between the Ionic half columns is rusticated and the windows have flat arches; the abundance of wall space giving the necessary strength which a ground storey should possess. Exception might be taken to the impost moulding upon which these arches rest, as being unnecessary. The upper storey is in Palladio's most ornate manner. The windows have architraves and consoles supporting pediments, alter- 
nately triangular and segmental, upon which are placed reclining figures. The podium to these windows is pierced with balustrades, while the Corinthian columns are unfluted and rest upon a continuous block immediately over the cornice of the lower order. An attic plainly treated with square windows crowns the whole building, the columnar lines being carried up and supporting statues. The illustration shows the successful angle treatment of the Ionic shaft to the ground storey-a difficulty which the Greeks never quite surmounted. The influence of Palladio's study in Rome is shown in the absence of the pedestal to the columns. Although built in brick and stucco, this palace must always remain a triumph of art over matter. The meanness of the material used is completely lost sight of in the superior excellence of a master design. In execution this has been considerably altered. Palladio shows it as a regular façade of seven bays with a central opening leading into a columned vestibule. Additional land to one side appears to have been acquired by his client, which throws the principal entrance out of the centre. Bertotti points out several faults, and after stating how he has endeavoured throughout his book to give the measurements of our architect's works as they were actually executed and with the greatest precision, in order to contribute to the advancement of art, he chides the architect, "N. N.," for altering the actual measurements in order to render them more proportionate, and also to hide certain defects which existed. With regard to the general proportions of the façade, we may remark that the Ionic columns are 9 diameters in height and are given an entablature of one-fifth the height of the columns. The Corinthian columns to the second storey have a height of $9^{\frac{1}{2}}$ diameters, but are less in height by one-eighth than those of the ground storey. This forms 


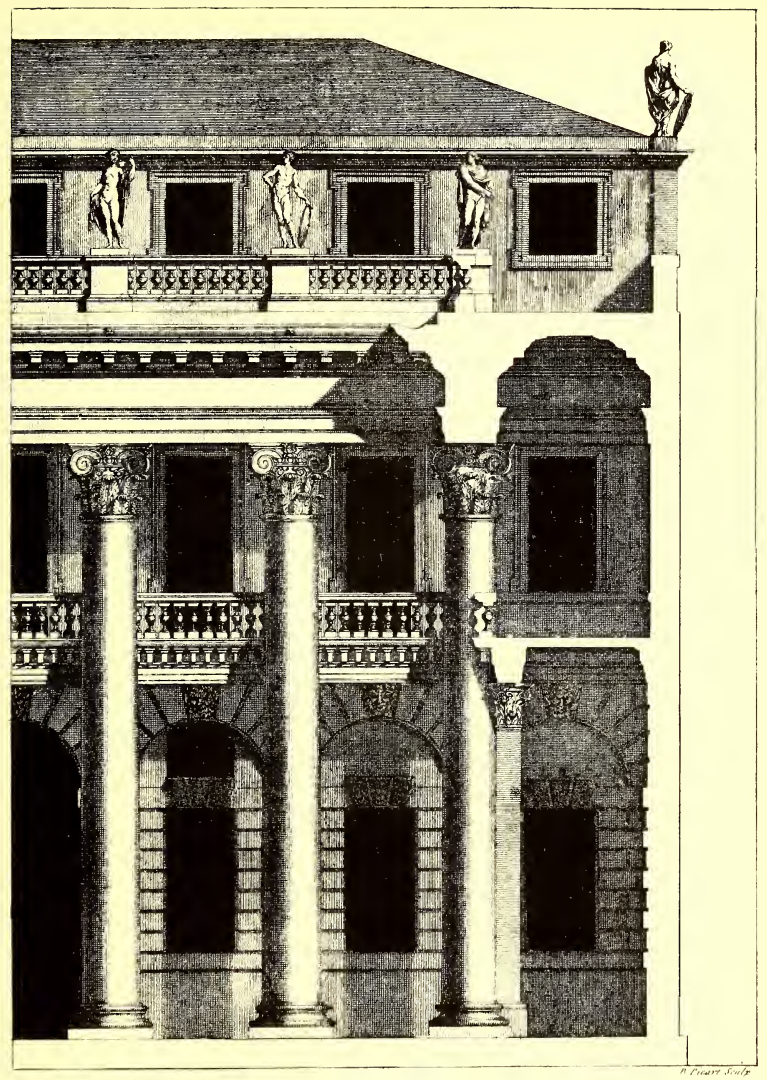

2I. PALAZZO PORTO, VICENZA.

DETAIL OF COURTYARD. 

a very pleasing proportion, and is obtained by continuing the line of the ground-floor columns upwards, to form those of the upper storey. This produces a gradual and continuous diminution. The attic storey has a height of onethird that of the Corinthian order. In plan the entrance vestibule is divided into three parts by isolated Ionic columns. These have angular capitals of the Roman type, resembling those of the Temple of Concord (Palladio, Book IV., Chapter XXX.), instead of the straight-faced type used in the façade. In that position it shows Palladio's good taste, for in having four faces these capitals can be made to correspond to those of the piers attached to the walls. The columns are $8 \frac{1}{2}$ diameters high, and support an impost moulding one-thirteenth of their height, showing how our architect often departed from his own rules of proportion. The Ionic order is employed in three different scales of proportion in this building, varying with the position and uses to which each was intended. The Ionic columns to the front façade have a height of 9 diameters, those of the courtyard at the back $9 \frac{1}{6}$ diameters, and those to the entrance $8 \frac{\mathrm{I}}{2}$ diameters, these latter having to support a solid vault. It is possible that Palladio followed Vitruvius in this, as the latter mentions in his Book I., Chapter II., " that variations may well be made from the regular proportions, in order to suit them to special circumstances." The Corinthian columns to the first floor are also raised upon a plinth. Their bases, being in a narrow street, would otherwise have been hidden by the projecting cornice of the lower order, whereas in the wide courtyard at the back this raising was unnecessary. Thus by the study of our architect's methods do we learn to overcome the difficulties of foreshortening, always an important consideration. 
The Palazzo Porto.-Palladio's classical studies are apparent in this building, of which he gives a plan, section and elevations. The building faces two streets, and the front portion only was executed. The entrances from each street lead through columned halls to a great central courtyard, open to the sky. This is surrounded by a colonnade of Composite columns embracing two storeys in height and crowned with entablature and balustrade (Plate $2 \mathrm{I}$ ). Behind this colonnade is a covered passage on each floor, which serves for communication between the front and back portions of the house. The passage on the first floor is supported on pilasters attached to the backs of these tall Composite columns. It is curious to observe that Palladio designed the front part of the house for the "master and his family, and the back part for the reception of strangers, that the one and the other may pass to and fro with more freedom, a custom which the ancients, especially the Greeks, held in great regard." He places the main staircase on one side of the courtyard, "that those who go up and down may necessarily have a prospect of the most beautiful part of the house, and that being in the middle it may serve the two separate parts of the fabrick." Palladio mentions Paul Veronese as the artist employed to paint portions of the interior. The exterior (Plate 22) is certainly one of the most pleasing of the master's efforts, and, in regard to arrangement, resembles that already shown in the Palazzo Thiene. A rusticated basement with square-headed windows, and circular relieving arches with carved keystones, supports a piano nobile of attached Ionic columns and entablature. Between the columns are square-headed windows surrounded by an architrave moulding, and provided with consoles carrying pediments alternately segmental and triangular. Over these pediments Palladio designed reclining figures, 


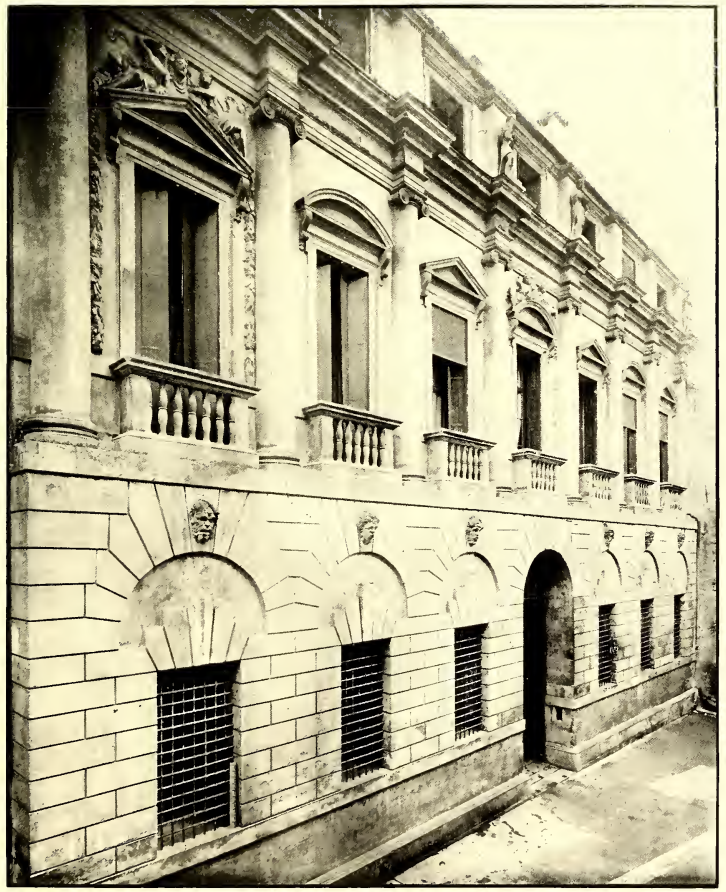

Alinari photo.

22. PALAZZO PORTO, VICENZA. 

but the view shows that only three groups are really executed, a central and two angle ones. This omission helps the façade, which might otherwise appear too complex and crowded. There is also another important difference between Palladio's design and that which was actually carried out. In the statues which decorate the attic storey Palladio shows a range of eight of these, resting on the top of the attic pilasters, whereas (Plate 22) there are only four, and they are placed immediately above the cornice in front of the pilasters. To our thinking this is an infinitely better position; there is something dangerous looking and gymnastic about free-standing sculpture at a great height from the ground.

Bertotti mentions in his book the extraordinary difference which occurs between our master's designs and those actually carried out, and after a description of each of his buildings gives, side by side, the measurements on the drawings of Palladio and the actual measurements as executed, which vary in nearly every case. He expresses surprise at this, but we are of opinion that it is a very common occurrence even in these days of accurate drawing and careful draughtsmanship, and that it is not to be wondered at during the period in which Palladio lived. In those days draughtsmanship appears to have been of a decidedly crude and unfinished description, although apparently sufficiently accurate for the purpose. This can be seen by looking at the autograph drawings of Palladio in the museum at Vicenza, and also in the Burlington-Devonshire collection in the library of the Royal Institute of British Architects.

The afore-mentioned town buildings are all that Palladio alludes to in his second book as having been carried out. He 
then proceeds to treat of the various types of atrium and of the private houses of the Greeks.

The Palazzo del Consiglio (Plate 23).-This is also known as the Palazzo del Capitanio, the Prefitizzio, Municipio, Loggia Bernarda, and Palazzo Communale. It is not mentioned in Palladio's book, and must therefore have been erected after its publication. It will be noticed that it is comparatively a small building, a portion only of the original design, and is situated opposite his masterpiece in the Piazza de' Signori. Thus we can see at one glance, as it were, one of his earliest and latest productions. The Composite half columns, without pedestals, are carried through two storeys and their entablature breaks round them and is crowned by a balustrade. The attic storey over is set well back, and does not interfere with the general proportions of the façade, which are excellent. The lower portion forms a triple arcade, and the upper storey has windows and balconies projecting forward and supported on triglyph brackets. The windows of this storey cut into the architrave of the main entablature, a defect in the design which is hidden by the outside blinds. The view also shows the dilapidated condition of this façade, the brickwork of the columns showing where the plaster has fallen off. Bertotti mentions that he examined very carefully the building and the surrounding ground, and was of opinion that the original design included seven openings, only three of which have been completed. In regard to the proportions of this building, the columns have $10 \frac{1}{3}$ diameters in height, not including the plinth on which they rest.

The entablature is in height about one-fifth of the column, and the arcades which are between the columns are in height $2 \frac{1}{5}$ times their width. The treatment of the side façade is 


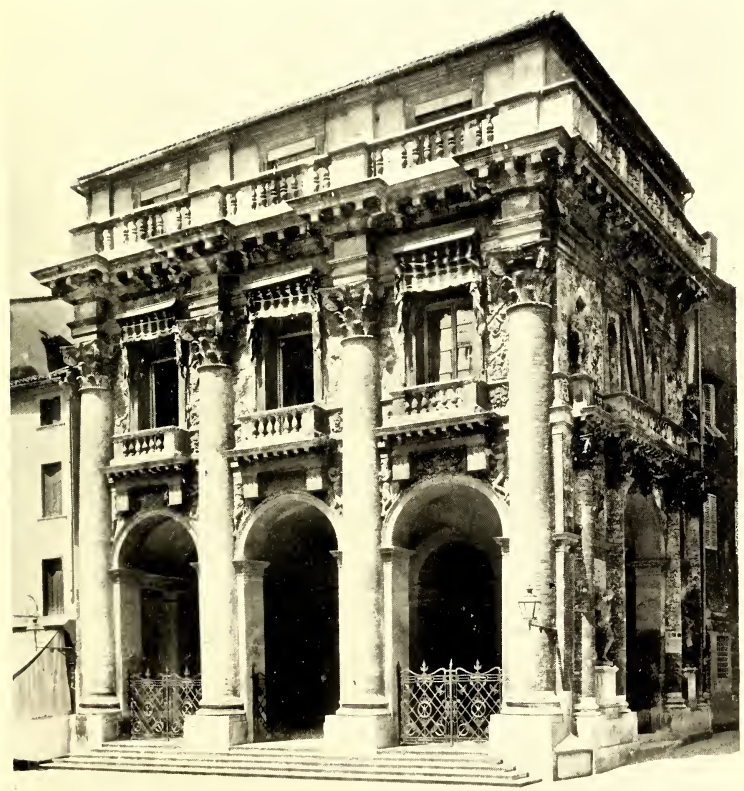

Alinari photo.]

23. PALAZZO DEL CONSIGLIO, VICENZA. 

different from the front, the main order not being carried round; a smaller Composite order of four half-columns is used instead. These range with the lower storey of the building, and rest on a continuous pedestal and support an entablature, without architrave, which corresponds with the projecting balconies of the front, the entablature being only one-eleventh part of the height of the columns.

The central intercolumniation of this façade is wider than the side ones and consists of an archway, the height of which is twice its width, with sculptured figures in the spandrels. The side intercolumniations have free-standing statues placed on pedestals. The upper storey of this façade has a serious defect, the architrave of the main entablature being cut into by the semicircular arch of the central window. All reviewers of Palladio's work refer to this blemish, and it certainly does interfere with the dignity and even the raison d'être of this important feature. The central upper window is flanked on each side by a pair of Doric pilasters, having between them a niche and statue, a very favourite treatment in after years in England, and much used by the brothers Adam, with whose name it is frequently associated. Bertotti considers that this building was probably erected after Palladio's death, or at any rate during his absence elsewhere, thus accounting for the faults abovementioned.

The Casa del Diavolo.-This is known in Vicenza as the "Antica Posta," and is called by Bertotti the "Casa Porto." It is another of Palladio's unfinished designs and does not appear in his own publications, but is illustrated by Bertotti, who, however, advances several reasons why he does not consider this building to be the work of Palladio, but that of Vincenzio Scamozzi. From the foundations which 
Bertotti discovered on the site he publishes a restored plan, in which he places a central columned entrance leading to an interior open courtyard with semicircular end, about 57 feet in length.

Two bays only of the façade have been completed, which indicate the immense scale adopted. Half columns of the Composite order rest on deep pedestals, the cornice of which forms the impost of the principal gateway. These columns are ro diameters in height, and from their abaci sculptured festoons, bound with oak leaves, stretch from one capital to another. The windows to the first storey are crowned with pediments, alternately segmental and triangular, and have projecting balconies, with balustrades supported by consoles. The entablature of the main order is one-fifth of the height of the column, and windows are placed in the frieze, in the manner of Peruzzi, to give light to the small rooms of the upper storey. The ground storey is marked by the elongated pedestals of the columns; the windows have flat arches, after the manner of Sanmichele, and the wall space over is rusticated. The façade is constructed in brick and stucco above the pedestal bases. Only a portion of the semicircular-ended court at the back has been constructed, but this shows that it was intended to decorate it with Corinthian half columns, embracing the two lower storeys and supporting a continuous balcony. This portion of the edifice seems to have been intended for the servants and domestic offices. The excessive height of the pedestals to the main façade order, which by our master's rule should not exceed one-third of the height of the column, is to be noticed. As to the plan, the main staircases as shown are too small, being circular, and only about 3 feet in width, but Palladio may have intended to place these elsewhere. The finished façade seems to have been intended for five intercolumniations; the central one, as 
shown by the arch on the ground storey, being wider than the rest. Bertotti, however, appears to disregard this arch way, and restores the façade as seven intercolumniations.

Other Town Houses (whose authorship is doubtful). -Among other town buildings in Vicenza, Bertotti mentions a house built in $\mathrm{I} 540$ for the Conte Trissino, but there is no evidence to show that it is Palladio's work. On the ground floor it is fronted by an arcade with wide piers, connected by semicircular arches. The first floor is decorated with coupled Corinthian pilasters, having no diminution in their shafts, resting on pedestals, and supporting an entablature one-fifth their height. The windows between the coupled pilasters have alternately triangular and segmental pediments. Bertotti does not consider this work to be authentic, as Palladio (if born in 15 I 8 ) would only have been twenty-two years old at the time of its erection, but if, as we have shown, it can be held that he was born in 1508 , this objection would not hold good.

The Pavilion for the Conti Valmarana.-This is situated near Vicenza, on the way to the Rotunda, and is always described as our architect's work, although not mentioned by Palladio. It forms what we should call in England a garden-house, and has three room placed side by side, the two outer ones being I 6 feet wide and the central one about I I feet 6 inches. These give on to a wide portico about 20 feet wide, extending the whole length of the three rooms, and having a colonnade of six Doric columns according to the proportions of Palladio, while a pediment is raised on the four inner columns. These rooms are on the first floor and are raised on an arched basement. 
House for Conte Bernard Schio.-This is regarded by many as one of Palladio's designs. A plan and elevation are given in Bertotti who, however, doubts if it was erected under his supervision. It is also held that Palladio's work consisted only in enlarging an older building, and this absolves him from many of the faults in the structure. The façade is almost 40 feet in length, and consists of a rusticated lower storey in which is a central entrance, spanned by a semicircular arch and having flat-headed windows on either side. The first storey is of the Corinthian order (half columns), between which are windows with architraves and pediments, while balconies with balustrades occupy the lower portion of the windows. The principal defect in the façade is that the main entablature is cut into in order to provide three windows to light the granaries, which occupy the upper storey. It is a defect, spoiling an otherwise elegant façade, and could have been avoided by the use of roof lights. 'It was probably effected by those who had the execution of the design.

House for the Conte Adrien Thiene.-This is yet another of Palladio's doubtful productions, and was constructed under the direction of Vincenzio Scamozzi, who does not mention its authorship. It is curious that Scamozzi, who carried out Palladio's design for the Villa Capra, did not even in that case mention Palladio's name. The plan consists of a central entrance leading to a vaulted hall occupying the whole depth of the building, and having rooms on each side; the main staircase being on one of these sides. The principal façade is designed so as to have an order to each storey. The lower storey has Corinthian, and the upper Composite columns; the windows of the ground storey are kept low, to allow for the springing 


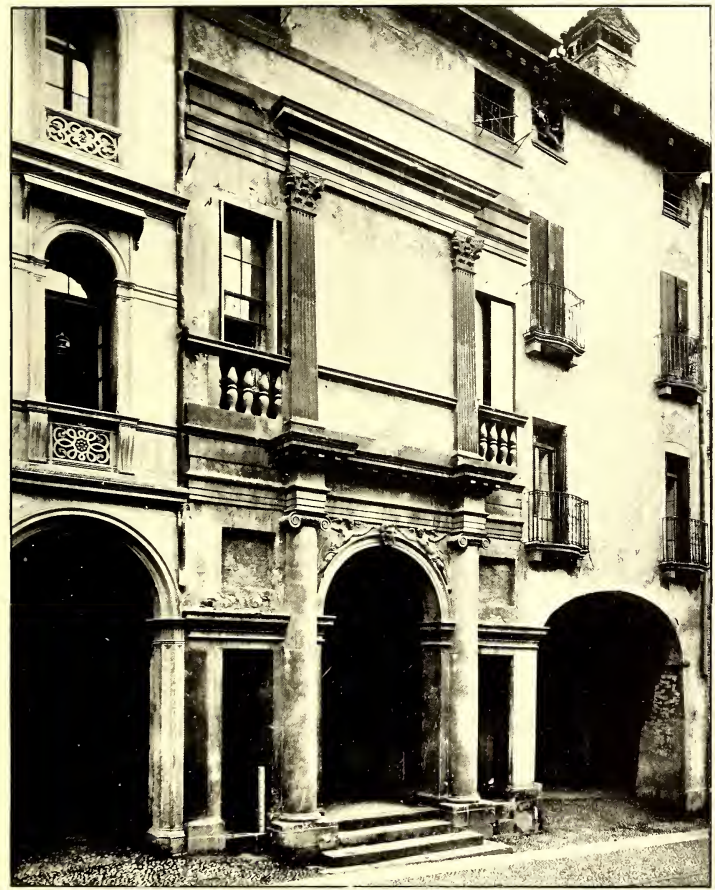

Almarifhoto.

24. THE HOUSE OF P'NLLADIO, VICENZA. 

of the vaults crowning the storey, and blank windows are placed over the lower ones. The windows of the first floor have architraves and pediments, alternately triangular and segmental, while balconies rest upon the cornice of the lower order. An attic crowns the whole façade; that to the garden having free-standing colonnades to each storey of the same order as the front.

The House of Palladio (Plate 24).-There appears to be no evidence that Palladio ever resided in this house, erected in 1556 ; indeed, according to Bertotti, there is direct evidence that he did not. At the same time, as an instance of one of our master's smaller works, which one would expect he might have designed for himself, it is an exceedingly interesting piece of work. The plan consists of a front and back corps de logis, with an open area between, to the side of which is the staircase. The façade is shown in Plate 24. The ground storey has Ionic columns of about 9 diameters in height, with entablature one-fifth of their height. A large centre semicircular-headed opening forms the chief entrance and has reclining figures in the spandrels. Smaller flat-headed openings are on either side. The first storey has Corinthian pilasters of a rather stumpy proportion, viz., $8 \frac{1}{4}$ diameters, and above is an attic storey, crowned with a modillion cornice. The blank space in the centre of the first storey is probably caused by the fact that the light for this room is obtained mostly from the interior court. In the vestibule are two niches containing statues representing Palladio and Architecture.

All the town houses mentioned above are at Vicenza, Palladio's native place. He was also the architect of a house erected at Udine, the metropolis of Friuli, which "was 
built from the foundations by Signor Floriano Antonini, a gentleman of the same town." It is of a square type of plan, two storeys in height; the central part, representing the hall, being of the whole height of the two storeys. The ground floor of this portion has Ionic half columns, and the first storey Corinthian half columns on pedestals, which latter are without bases, while a pediment crowns the central portion. The main roof is hipped on all sides. A plan and elevation are given in Palladio's second book, and indeed it forms his first illustration when writing of town houses; it is not, however, one of his best examples, and was in all probability an early work.

Another design, which shows a very original treatment of plan for a narrow site, is that for the Conte Giovanni Battista della Torre, at Verona. No elevation of the exterior is given in Palladio's book, but merely a plan and longitudinal section.

The entrances are i I feet 6 inches wide on the narrow sides facing streets, and lead to two courts, each 57 feet long by 34 feet wide. Wedged in between these two courts are twelve Ionic columns grouped to support the upper hall. The lower hall leads to an elliptical main staircase and secondary stairs. The façades of these courts are ornamented with Ionic and Corinthian pilasters and entablatures, the upper order being placed on pedestals. A gallery is carried round on the top of the Ionic entablature at the first floor level, for the purpose of intercommunication. There is a spacious breadth about this plan which is very pleasing and satisfactory. 


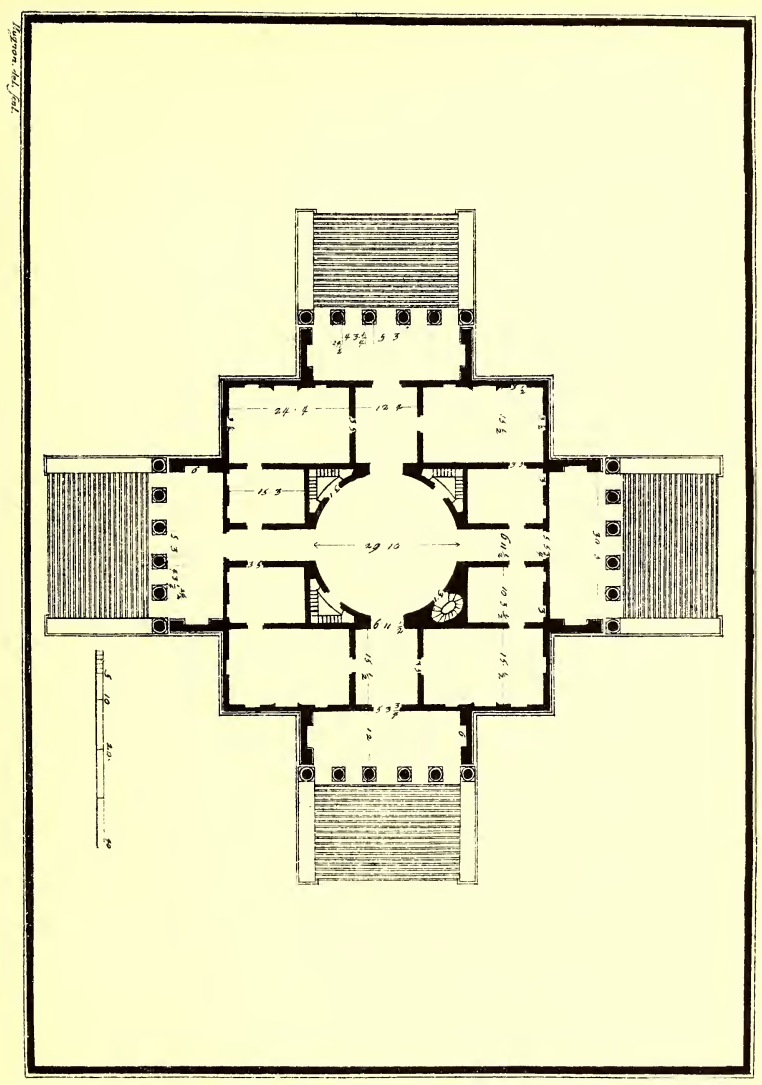

25. THE VILLA CAPRA (THE "ROTONDA"), NEAR VICENZA. PLAN. 



\section{CHAPTER VI}

\section{COUNTRY HOUSES}

DALLADIO introduces the subject of country houses in I his second book, Chapter XII., with a few preliminary remarks on situation and the various compartments, etc., in these words: "As certainly 'tis highly creditable and convenient for a gentleman to have a house in the city, where he is obliged sometimes to reside, either as occupying some public post in the government, or for the management of his own private affairs; so perhaps he may receive no less pleasure and advantage from a house in the country, where he passes the rest of his time in seeing and improving his own possessions, in augmenting his substance by industry and agriculture, where, by exercising himself either in walking or on horseback (which are only proper for the country), he preserves his body strong and healthy; and where, in a word, the mind being over-laboured by the fatigue of the city, will be singularly recruited and re-created: so that he may then quietly apply himself to the study of books, or the contemplation of nature, in imitation of those ancient sages who, on such accounts, used frequently to retire to the like places; where being visited by their virtuous friends and relations, and possessing Pleasure houses, Gardens, Fountains, and such other objects of diversion, but above all their own virtue, they could easily attain that highest pitch of a happy life, that on this earth can possibly be enjoyed."

Thus were the delights of the country appreciated in our 
master's time, although certainly not by means of the modern Saturday to Monday flying visit.

The open position and extended space are then dwelt on in comparison with town sites, and the necessity for finding " commodious and healthy places." A position near a river was considered conducive to "the beauty and convenience of the building," refreshing the air in summer and of use in watering the fields and gardens. Palladio rightly condemns " dead and stagnant waters, because these generate the very worst of air ... and gnats and other troublesome little animals, which breed in putrefied and marshy waters." This is well understood in these days in selecting a site, yet it is curious to note that Inigo Jones in a side-note to the above remark, states that "it is a beautiful and commodious thing to build a country house upon a moat, for the easy transportation of goods and provisions, besides one may easily water gardens and other grounds."

This is in direct opposition to Palladio's advice and also to the teaching of modern sanitary science. There is also the necessity for a good water supply and fresh air, which cannot be obtained in valleys surrounded by mountains, and for good views, by placing the building on high ground. Thus, after having found an airy, pleasant, advantageous, and healthy situation, Palladio continues that two sorts of houses are necessary, one for the master and his family, the other for the farmer (i.e., steward). In these the need for covered ways (piazzas) which appear in many of Palladio's designs, and labourers' rooms are dwelt upon. The stalls and stables, he remarks, should be placed at some distance from the house, as also sheep, pigeons, etc. ; the granaries and storehouses must be lighted from the north, for the better preservation of corn. Hay-lofts may be to the south, so that the hay may be well dried by the sun; barns for the 


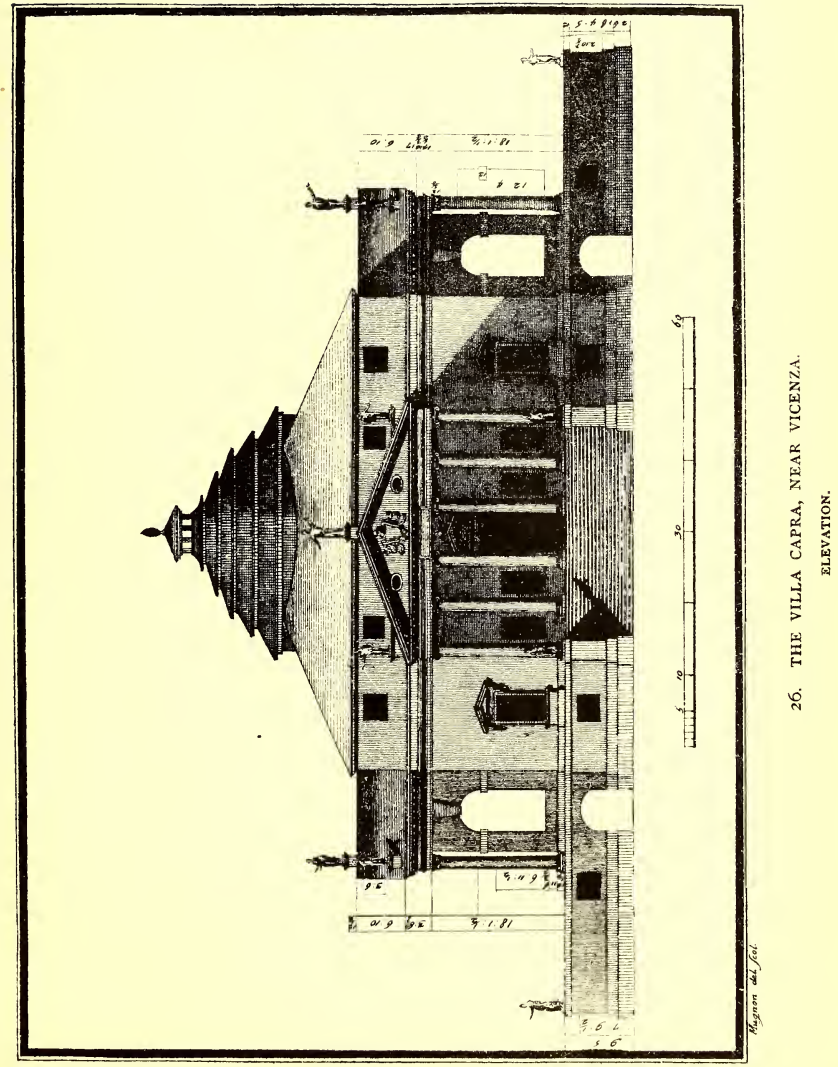



threshing of corn should be at some distance from the house because of the dust. Thus does Palladio refer in detail to the position of the various dependencies of a country house before giving the plans of the houses he erected.

The Italian sixteenth-century country house would therefore seem to have had very different requirements to one in modern England. In all of our master's draughts a central corps de logis is provided for the master and his family, and this has generally a frontispiece of columns, either flush with the front wall or in advance, and crowned with entablature and pediment. On either side are the wings containing the steward's apartments, the stables, the stores and granaries. Such dependencies in England are generally placed at some distance from the house and often do not form part of the group. Palladio's types of country houses may be divided as follows in regard to plan:

Type I.-Block type (as the Villa Capra) without wings.

Type 2.-Central block (or corps de logis) with quadrangle.

Type 3.-Do., do., with straight wings.

Type 4.-Do., do., with quadrant wings.

Type 5.-Do., do., with returned wings.

The kitchen and offices are invariably placed in a basement or lower storey, and an upper storey is often provided and used for granaries.

The Villa Capra (also known as the "Rotonda," from its circular hall), (Plates 25, 26, 27 and 28).-It was originally designed for Signor Paolo Armerico, who is described as "Referendary" to Popes Pius IV. and V. He appears to have been of a cultured disposition, for "after having travelled a long time to improve himself, and being come to settle at last in his own country, after the death of all his 
friends chose his abode at a country house he had on a hill."

It is situated at the eastern base of Monte Berico, about one and a half miles from the town of Vicenza. Palladio describes its situation "as advantageous and delicious as can be desired, being seated on a hillock of a most easy ascent, at the foot of which runs the Bacchiglione, a navigable river." Plates 26 and 27 give an elevation and section.

Our master seems to have been much impressed by the beauty of the site, for he goes on to describe how it is surrounded by several hills " that seem to form a great theatre," and which besides are all of them cultivated, being very fertile, abounding with excellent fruits and vineyards. This is probably the best known of all Palladio's works, and owes much to its open position and to the excellent views on all sides. It was in consequence of these views that our master probably placed porticoes to each of its four faces. It has a central hall, 40 feet in diameter, carried the whole height of the building, which was to receive its light by means of circular windows in the dome. The hall has a projecting gallery at the first floor level. Four angular staircases bring the central portion to a square, around which are placed the living apartments. On each of its four façades is an Ionic colonnade projecting about i 4 feet and having an internal width of about 34 feet. The basement, containing the kitchen, etc., extends under the whole of the house, "for the use and conveniency of the family," as Palladio quaintly puts it. The ground floor is raised some I I feet 6 inches by means of wide flights of steps, giving access to each portico. For a sunny climate the Rotonda is undoubtedly a very excellent and suitable design, the central hall forming a convenient retreat from the heat of the summer sun, while the projecting porticoes are so placed as to catch every available ray of 


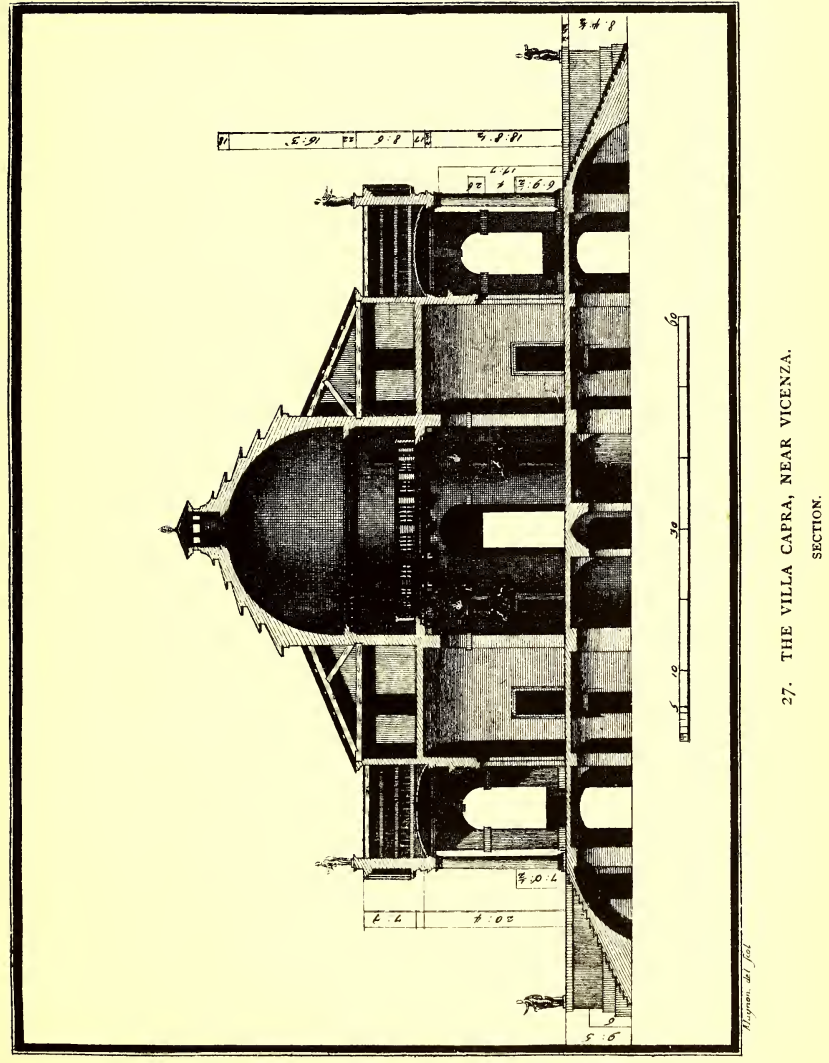



sunshine if so desired, meanwhile also protecting the house proper by means of their deep shadow.

The bedrooms, however suitable for the period and country, would undoubtedly be dark and inappropriate in England, as also the passages leading from the central hall to each portico.

Inigo Jones's remarks on this house are not of great interest. He remarks that "it stands very solid and firm," and "that a great sum of money must have been spent in the building of this house and especially for the terraces." In his time "the lanthorn at the top of the cupola is not set on, but a net to cover the top hole to keep out the flies;" also that "the tyling does not look well, considering the richness of the statues and the beauty of the building." It is to be presumed that a lead-covered roof would have been preferable (see Plate 28).

In spite of these drawbacks, this design has exercised an extraordinary fascination for European architects, who have imitated it again and again. The first imitation in England appears to have been Mereworth Castle in Kent, by Colin Campbell, the architect. It was also copied by Lord Burlington in 1729 in his villa at Chiswick (used as an asylum), which now belongs to the Duke of Devonshire, and on a larger scale for the Earl of Westmoreland at Foot's Cray Place, Kent (now occupied by S. J. Waring, Esq.), and also at Nuthall, Notts. On the continent it served as a model for the original Château of Bagatelle, near Paris, also for the Château of Marly-le-Roi (since destroyed), a building which was erected for Louis XIV. by the architect, J. H. Mansart, in 1676 . The sculptor Canova also built a house at Inverigo in Italy after the same design. Like the "Teatro Olimpico" at Vicenza, it was still unfinished when Palladio died, and it was left to Scamozzi to finish his master's work, 
which he accomplished, according to his own account, with many alterations and improvements. Palladio tells us "above the great rooms surrounding the hall there is a platform to walk on $\mathrm{I}^{\frac{\mathrm{T}}{2}}$ feet broad. The exterior view shows the somewhat dilapidated condition of this building, and also that the windows in the dome are not executed, the light being obtained from a very small lantern at the top of it.

House at Bagnolo, near Lonego, for the Conti Pisani.-This is a one-storeyed house with projecting Doric portico set upon one side of a colonnaded quadrangle, around which are grouped the stables, granaries and cellars. The ground floor is raised 7 feet above the adjoining ground. Palladio refers to, and excuses the position of the stairs, as being dark, because they would only be used in going to the kitchens or the attics. In two-storeyed houses, he says he has taken care to make the staircases "lightsome and in convenient places."

Bertotti mentions that the wings were scarcely commenced, and that the plan itself has been varied considerably in execution; only one of the porticoes being completed, viz., that formed in a line with the building. This is one of the few country house designs to which Palladio intended giving a complete quadrangle and is of type 2 (page 6I).

House at La Frata for the Nobile Francisco BADOERO.-Situated upon a tributary of the Adige, upon a slight ascent, this building is of type 4, which in the following centuries was much used in England. In all of Palladio's country houses symmetry is the ruling idea. He evidently had no sympathy with that unbalanced planning which the architect of the middle of the last century endeavoured to associate with country buildings. In this case 


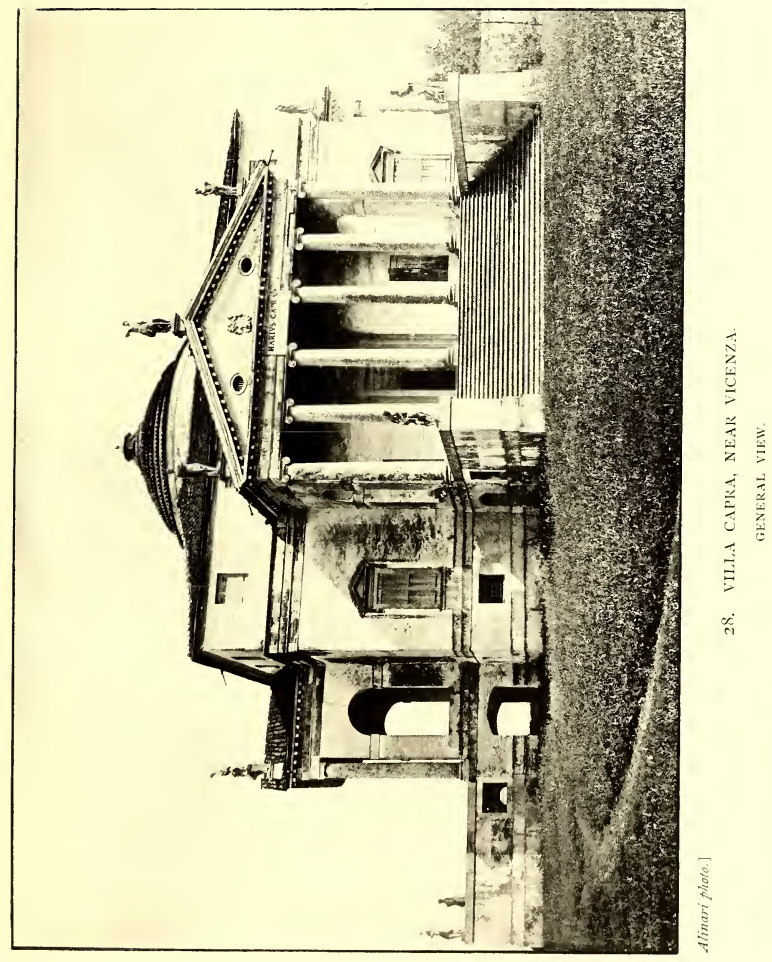



the corps de logis is a square one-storeyed structure with front and rear Ionic portico (this last omitted in execution) supporting entablature and pediment; the whole crowned with a hipped roof. The principal floor is raised five feet. The kitchens are in the basement and the granaries in the roof. The wings are formed as a quadrant on each side of the main block and have a colonnade, behind which are arranged the stables and the steward's apartments. In execution it differs considerably from Palladio's original design, in which a second portico is planned, and the exterior staircase towards the court is differently arranged, while the interior decoration in "grotesques," which is mentioned, was not carried out or has been destroyed.

House at Casalto for the Nobile Marco Zeno.This consists of a principal square block, about 70 feet by 60 feet, containing the living-rooms, on either side of which are returned colonnades, and is of the type 5. As in all Palladio's designs, the ground floor is well elevated above the ground. The wings are returned, one side containing the stabling and the other the granaries. The front of the main block is carried up two storeys, and is very plainly treated, the usual Classical columns being absent. The length of the hall is twice the width-a favourite proportion of Palladio, but in many of the other dimensions these vary considerably from the description in his own book. In regard to this, Bertotti suggests that it may have been executed from the original by another architect.

House at Gambarare, on the river Brenta, for the Nobili Nicolo and Luigi de Foscari.-This is of the square type without wings, and measures about 73 feet by 53 feet. The ground floor is raised about 12 feet 
6 inches, the kitchens being placed under, and above are bedrooms. Flights of steps, front and back, lead to a centrally placed portico and pediment of the Ionic order. The plan shows two staircases, one of them having circular ends. This example is interesting as being the forerunner of many of the eighteenth-century (or pediment and portico) houses in England; but curiously it is not even mentioned in Bertotti's work.

House at Maser for Monsignore Daniele Barbero (Plates 29, 30).-This was erected on a mound, and has a central advancing block of two storeys in height, with straight arcaded wings, returned backwards on each side, and connecting the main rooms with the stable and kitchen wings. The whole forms an extent of about 280 English feet in length. The courtyard at the back is level with the first floor of the main building. The front view is given in Plate No. 30, and gives a very good idea of the setting of many of our master's country designs, and also shows one of the weak points of Italian country architecture, viz., the poor and ineffective treatment of the chimneys, which in this, as in many cases, appear merely as circular flue-pipes without any attempt at grouping or harmonizing with the architecture. In most of Palladio's own drawings no chimney stacks are shown. This view also shows the Ionic columns ( 3 feet in diameter) of the front, with an unusual arrangement of broken cornice and central window. The capitals are of the angular Ionic form which Palladio had noticed in describing the Temple of Fortuna Virilis at Rome. In the centre of the back courtyard is a semicircular recess ornamented with Ionic pilasters, statues, sculptured cornices and festoons, and in the centre of this recess is a small basin through which running water passes 


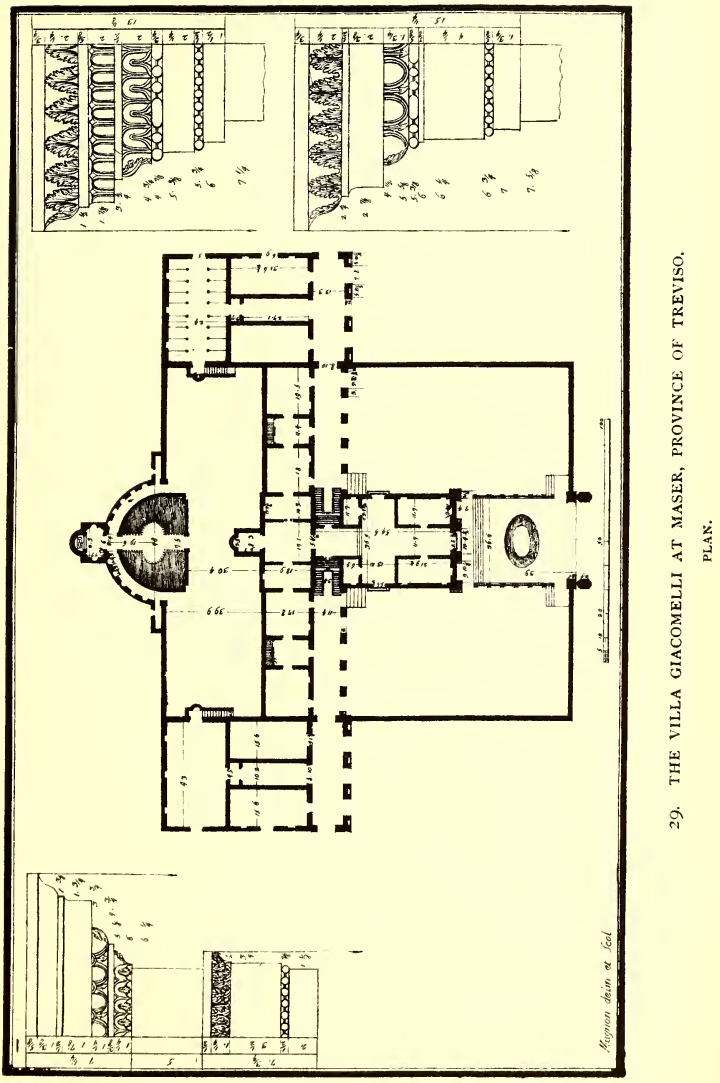



into a lake; from whence it is led by pipes to different portions of the house. The first floor of this design is of more importance than usual, no doubt, because it is level with the rear courtyard. The windows of this storey which give on to the courtyard are perhaps somewhat too close to those of the floor beneath. The hall is of cruciform plan, and the staircases are entered from the arcades (see Plate 29).

House at Montagnana for Nobile Francisco Pisani. -The plan of this, which is unusual, consists of a central block (the only part completed) about 80 feet square, containing a columned hall with rooms on either side, two storeys in height and two elliptical open newel staircases at the rear of the house. On both sides of the main building, at a distance of 30 feet, are two oblong structures containing three rooms on each floor; connected with the main building by galleries at the first floor level. This peculiar plan was necessary because two streets cut the façade into three parts. The front of the main building is ornamented with Doric and Ionic half columns with their entablatures; neither the Doric columns nor the Ionic pedestals having bases. Four niches in the porch contain statues of the Seasons by Alessandro Vittoria, a pupil of Sansovino. Palladio mentions that this house was unfinished, owing to his client's death. It is to be regretted that in his book few sections of his country houses are given; he seems to have thought a plan and one elevation sufficient to explain his designs, but Bertotti has in most cases made up the deficiency, and in this case deals at length with the proportions of the Doric and Ionic columns in this façade. He finds that the entablatures are about one-fourth the height of the column, whereas in Palladio's treatise one-fourth is given 
as the correct height for the Doric, and one-fifth for the Ionic entablature. The similarity is supposed to result from Palladio's desire to equalize these features in each storey. In reality it shows that Palladio, like all sensible men, only made rules of this sort for general guidance, and allowed each case to be treated according to its requirements.

House at Piombino for the Nobile Giorgio Cornaro. - This bears a striking resemblance to the central portion of the last design, except that it has an open portico to each façade. It consists of a central block about 70 feet square, with columned hall, around which are grouped the rooms. In the centre of each façade is a two-storeyed portico; the lower Ionic, without pedestals, the upper Corinthian, on pedestals, supporting entablature and pediment. On either side of the main building are single room annexes, used for the kitchens, servants' bedrooms, etc. The ground floor is only partly vaulted. The hall leading from the colonnade has four Ionic columns with angular volutes, and this apartment, which has a proportion of length to width as five to six, has semicircular niches. This building has been very much varied in execution from Palladio's description, especially in the proportions of the rooms.

House at Morocco (Between Venice and Trevigi) FOR LeONARDo Mocenigo.-In the original design this has a central block about 100 feet by 75 feet, with a large hall about 35 feet wide, extending from front to back, with central double staircase in single flights. On the façade are colonnades of the Ionic and Corinthian order superposed. The returned wings were to contain the offices, wine-presses and stabling. 


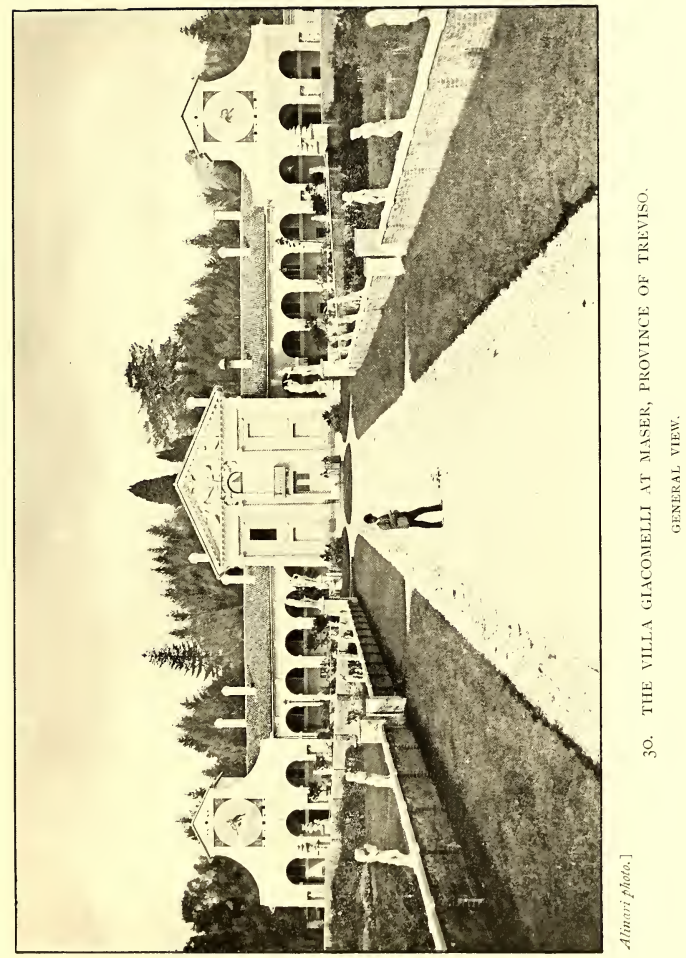



According to Palladio's designs the ground floor was to be used as cellars, the mezzanines above for granaries and servants, while the upper storeys contained the master's apartments. Only a very small portion of the original scheme has been carried out, but if completed it would have been in marked contrast to Palladio's usual practice, for it is four storeys in height, a very unusual arrangement for a country house. It has been much criticised as being more in harmony with town buildings. Bertotti refers to it curiously, as being less able to resist earthquakes.

House at Panzolo for Leonardo Emo.-This is three miles from Castel-Franco, it is somewhat unusual in plan and seems to have been carried out without much departure from Palladio's own ideas. It is of the type 3 , a central block about 70 feet square, with straight wings on either side consisting of apartments, in front of which is an arcade. The buildings are one storey in height, the central block having a high basement in which are the kitchen and offices. In his description of the house Palladio lays great stress on the fact that, owing to the covered arcades, people can go everywhere under shelter. This is true, but when introduced into England the system of arcades results in dark and sunless rooms which are quite out of place in a grey climate.

House at Final for the Nobile Biagio SarraCENO.-This is of the type 5 in plan, having a central block about 70 feet by 45 feet, with returned wings, containing the kitchens, stabling and stores. The ground floor is raised, as usual, about 6 feet from the ground, and is approached by a flight of steps. The central portion only 
of the design has been executed, consisting of a portico, hall and four rooms; cellars are placed in the basement, and above the principal apartments is a granary extending over the whole house.

House at Ghizzole for Signor Girolamo Ragona. -This is also of the type 5 in plan, consisting originally of a central block 55 feet square, from the side of which wings were to have branched off, returned towards the front. The ground floor was to be about i 4 feet above the ground, and approached by a flight of steps having under them a central entrance to the kitchen and service apartments. The central block is two storeys in height above the basement. A small portion only of the design has been completed. It was on the site of an old Gothic house whose walls existed, and two rooms of the central block and a portico were apparently added by our master.

House at Pogliana for Conte Pogliana.-This is situated twenty miles from Vicenza. It consists of a central building two storeys in height, with a lower building on each side, beyond which are colonnades round three sides of a square, serving for inter-communication with the stabling and out-houses. The cellars are below and the granaries are above in the main building. Palladio mentions that one side is utilized as a yard and the other as a garden.

As is usual in our master's designs, only the central block has been executed, and even two apartments of this are wanting. The house was adorned by Bernardino India and Anselino Canera, painters of Verona, and also by Bartholomeo Rodolfi, sculptor of the same place. In regard to the elevation the usual portico is absent, its place being 
taken by three openings, having double arches, in a very similar manner to that so frequently used by the brothers Adam in the eighteenth century. The principal floor is raised about six feet and consists of a portico, hall, six rooms and two staircases, the stairs being so high as to render them very uncomfortable according to Bertotti. The proportions of the various rooms are as follows: the portico has a length of two and one-third times, and the hall one and two-thirds times its width; the large rooms a length of two and one-third times their width; the smaller rooms being square. All have the same height, viz., one and one-sixth times the width. Most of the apartments in Palladio's designs appear to have some arithmetical proportion, but we have not in every case dealt with them for fear of wearying the reader. The façades are also arranged similarly; in this instance the length of the corps de logis is divided into four parts, two of which are employed for the portico and one each for the portion containing the window on each side.

House at Liziera, Near Vicenza, for Signor Giovanni Francesco Valmarana.-In plan this is of the type I, consisting of a block, about 85 feet by 65 feet, with porticoes on the front and back, two storeys in height; the lower Ionic and the upper Corinthian. Four staircases were to be reached through the porticoes, these latter giving on to a rear and front courtyard. Only the hall, two rooms, a portico with Ionic columns, and an attic over have been executed. It is curious to observe that Palladio talks of this building as completed, but he does this in other cases, where his designs were scarcely commenced. The architects Bertotti, Leoni, and "N. N." have all published drawings which they think correspond with the original ideas of Palladio; 
as these vary considerably it is of no importance to discuss them.

House at Meledo for the Conti Francesco And Ludovico DE Trissini (Plate 3I).-The plan is of an unusual and ambitious kind, being a combination of types I, 4, and 5. The central block resembles the "Rotonda," near Vicenza, and has quadrant wings. In front of these are other returned wings. The main block was to be about I 20 feet by 90 feet, and has a central circular hall about 40 feet in diameter surrounded by various rooms and staircases. A columned portico of the Corinthian order is on each face, placed there because " every front of the house has a very fine prospect." Palladio describes its situation "as very fine, being on a hill that's washed by a little river, in the midst of a spacious plain and on a well-frequented road." The house proper is set well away from the lower portico by means of the quadrant galleries; a great improvement on some of the smaller plans, in which the granaries and farm offices are in immediate proximity thereto. The cupola crowning the whole was intended to contain windows to light the central circular hall, and forms a fine terminal to the group, but in execution these windows have been omitted. The kitchens, as usually seen in smaller plans, were in the basement and the granaries in the roof.

House at Campiglia for Signor Marco Repeta.This appears to have been designed with different intentions to the generality of Palladio's designs. The centre block was omitted and instead a series of rooms fronted on a portico forming three parts of a square, so that the "farm buildings are of the same order with that of the master's itself." The angle porticoes to the front of the house are 


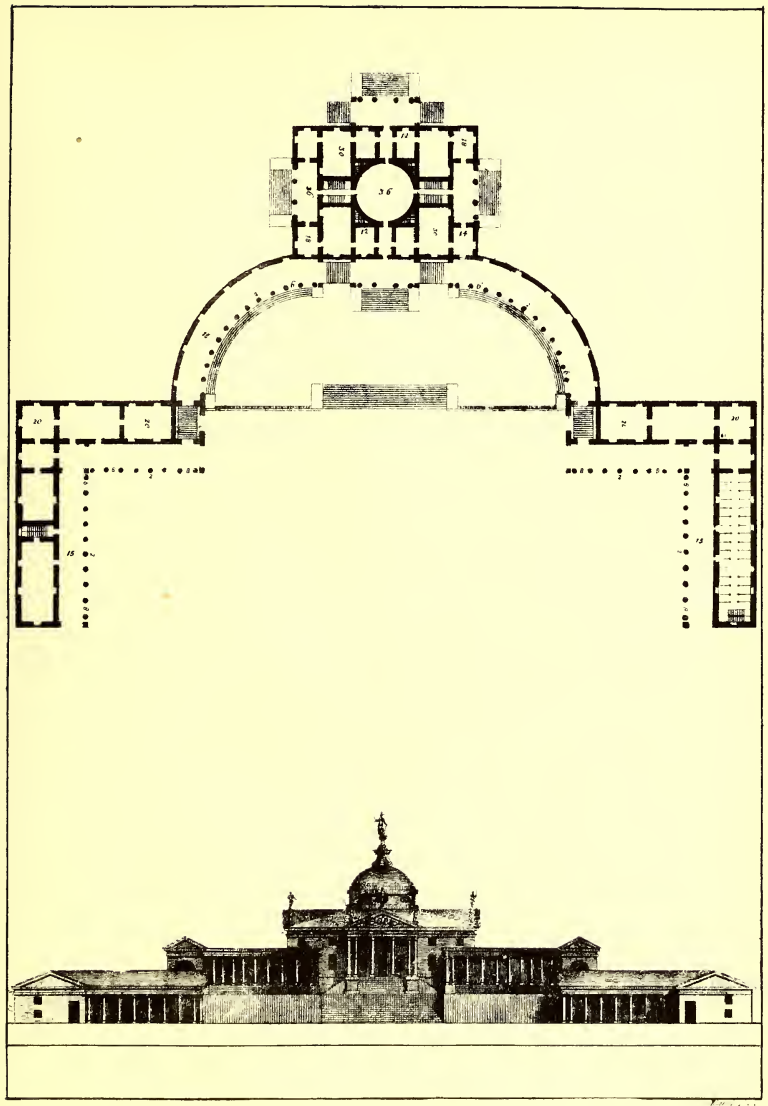

31. HOUSE AT MELEDO. 

peculiar, and so are the divers chambers, each one dedicated to some particular virtue-Justice, Charity, etc., "with eulogiums and pictures appropriate to each." These were painted by Battista Maganza, a Vicentine painter.

When Bertotti visited the place he found that it had been burnt, and a new building erected in quite a different character.

House at Cigogna for the Conti Eduardo and Teodoro de Thiene.-It is of type 4 in plan, viz., a central block with quadrant wings, connecting with cellars and granaries on either side. The ground floor is well raised as usual, and the front and the back façades have Corinthian porticoes; the columns extending two storeys in height and crowned with entablature and pediment. The angle rooms terminating the façade are carried up as turrets. It is shown thus in Palladio's book, and he clearly states that it was begun during his lifetime, but the building must have progressed very slowly, for when Bertotti visited it, he mentions that without the plans, he could make nothing of it, as only one of the side arcades had been erected, and even that was of a different design and proportion to that shown in Palladio's plan.

House at Angarano (near the Brenta), for the Conte Giacomo Angarano, is another of the unexecuted designs. According to Palladio's book, it has a plan of type 5 , but with additional colonnades and courts. It forms a most admirable arrangement, " the court or yard for the country necessaries and the garden being within convenient distance, and yet well away from the house proper." The colonnades to which Palladio attaches so much import- 
ance in country houses, for the purpose of reaching each part under cover, are perhaps rather overdone in this case. The central block about 65 feet square has attached Corinthian columns, two storeys in height, surmounted by entablature and pediment. Although Palladio mentions this as having been begun, yet apparently only a few Doric columns were actually erected, and the house which exists was designed by Dominique Marguti, an architect who died in Venice in $172 \mathrm{I}$, according to Temanza, in his life of Palladio (p. 367).

House at Quinto for Conte Ottavo Thiene.-This is situated about five miles from Vicenza, and is one of Palladio's most monumental efforts in regard to plan. $\mathrm{He}$ refers to it as a palace, and adds, " the situation is very fine, for it has the Tessina on one side and a pretty large branch of the same river on the other." Only a small portion has been executed. It does not correspond with any of the types of plan previously mentioned. The entrance is by means of a hexastyle Doric colonnade into the main court, surrounded by buildings on all sides. The use of these rooms are ill defined in Palladio's book, but the plan and section will indicate their symmetrical disposition. $\mathrm{He}$ mentions that there are no principal stairs, owing to the fact that the upper part of the house "serves only for wardrobes, stores, and lodgings for servants." As before mentioned, this plan is on a magnificent scale, and it seems unfortunate we have so little information of our master's intentions and that so small a portion of it has been built. It has been surmised that the colonnades on either side of the interior court were to be the entrances to the house for visitors-in imitation of the Greek custom as mentioned by Vitruvius, Book VI., Chapter X.-in which they lived 
apart from their hosts, and complete liberty was accorded to them during their sojourn.

House at Lonedo for Signor Girolamo de Godi. - This is also of an ambitious type, and is situated near a river. It was erected by Palladio in $\mathrm{I} 542$, or as some say in 1540 . The central block is raised about 15 feet above the ground, and is about I Io feet by 55 feet; this has been entirely completed and shows deviations from the original design. The kitchen and cellars are in the basement and the granaries are above. This main block was designed to have an entrance courtyard to itself, and there are other courts on either side, around which were to be grouped the stabling and outbuildings. The façades are a very poor example of our master's genius, due to the fact of its being an early effort perhaps. It is an instance in which he has dispensed with the usual portico and pediment. The house was decorated by three painters-Gualterio Padoano, Battista del Moro, of Verona, and Battista Venetiano.

House at Santa Sophia for Conte Marc Antonio SAREGo, is situated nearly five miles from Verona, and is yet another of his uncompleted works differing from his drawings. In general arrangement the plan is of type 2, viz., an open court, quadrangular in form, surrounded by a colonnade, with two storeys of rooms behind, this part being reserved for the family apartments. In front of this are two projecting wings containing the stabling, etc. The columns are Ionic and include two storeys, and are rusticated as to their shafts, "as seems to become a country house, to which nice and finished works bear not so true a resemblance as plain and natural ones." The first floor galleries are supported on pilasters attached to the lower sides of the Ionic 
columns, as in some of our master's town designs; while a balustrade is placed between the columns at the first floor level.

House at La Miga for the Conte Annibale Sarego, is yet another unfinished design. Although Palladio usually grouped the stabling and farm buildings to form part of the design, this is an example of their being separate. It is of the block type I, about 80 feet by 65 feet, with twostoreyed portico of Doric and Ionic columns in front. It was intended to be crowned with a hipped roof on all sides.

The foregoing country-house designs are all mentioned in Palladio's book as being erected or partly erected. After describing them he goes on to discuss the country houses of the ancients, referring to the remarks and instructions of Vitruvius. He then proceeds to give draughts of "inventions suited to different situations," but as these were not carried out we do not intend to describe them, but refer the reader to Palladio's book. Before leaving the subject, we might mention the design for Signor Leonardo Mocenigo, consisting of a central block connected by four quadrants to angle blocks, containing the stabling and dependencies, because it was followed in England at Kedlestone Hall by the brothers Adam and by other architects. If executed it would undoubtedly have formed one of Palladio's finest country palaces. Bertotti adds a section which shows the treatment of the interior courtyard.

There are ten other houses not mentioned by Palladio which are often attributed to him. These are given in Bertotti's book and may be briefly referred to here. 
The House at Montecchio Precalzin, for Signor Pietro Cerato, is of type $\mathrm{I}$ as regards plan, and has a principal floor, raised about 8 feet above the ground and approached by an external staircase. It is of the usual plan, consisting of a hall, three large rooms and one small one, and a badly-planned staircase leading to granaries in the roof.

The kitchens and servants' offices are placed in the basement. Externally the three floors are frankly expressed, the projecting porch is without columns and has a pedimented top, while the walls are crowned by a cornice.

The House at Montecchio Precalzin, belonging to The Contessa Tornieri Schio, is of a similar type, but without a projecting porch. It was only partly built. The angle rooms are shown, carried up as towers. A more ancient house originally occupied the site, and it is believed that Palladio altered this into the present shape, the Count having instructed him not to destroy the ancient walls.

House at Criccoli for the Conti TRissino.-This is generally quoted as our master's first work, and appears to have been an alteration to a previous building. Bertotti describes it as restored in 1536 , remarking that Palladio was only eighteen years old, and that this was a reason for presuming that it was not his design. This reason, however, in the light of more recent chronology, does not exist, as, if we are to believe Gualdo, Palladio was twenty-eight years of age at this time. Some date this building as I534. In plan the building is of type $\mathrm{I}$, the central portion of the façade being in two storeys and ornamented with Ionic and Corinthian pilasters. 
The House near Vicenza, for the Conte Tornieri, is also supposed to be a restoration by Palladio. It is near Vicenza, on the road to Verona, and consists of a ground and principal floor and attics. Side wings are also provided for the stables and outhouses, etc. The ground storey in this case is about to feet 6 inches in height. The principal floor has a portico of four columns of the Ionic order, those to the wings being of the Doric order.

House at Caldogno for Signor Pietro Caldogno.This was erected in 1570 , and is probably an alteration to an existing building, as traces indicate that it was not all built at one time. It is of type I in plan, of three storeys, utilized in the usual way. There are no orders, however, the portico being set back in the building and the openings formed as rusticated arcades. The interior has frescoes by Paul Caliari, Jean Antoine Fafolo and Jules Carpioni.

House at Retorgole for the Conte Bissari.During Bertotti's time this was in a ruinous condition, and he relates that, owing to inundations, he had difficulty in measuring it, and that great damage had been done to the building in consequence. His drawings are made up on account of this from various members scattered about the site. It had three storeys, the stabling and farm buildings being in separate disconnected wings with Doric porticoes, the columns having no bases. The portico is Ionic, and over its entablature is an attic of windows crowned with a pediment, an unusual treatment.

House at Bertesina for Signor Marcello.-This is about two miles from Vicenza, and is of type I in regard to plan. It has a large vestibule in the centre of one side, 
and a hall, cruciform in plan, on the other. There is the usual basement, about 8 feet deep, containing the offices, and the principal floor is vaulted. There is no evidence that it is Palladio's design. The façade is unusual, the walls being ornamented with Corinthian pilasters on pedestals.

The House at Malcontenta, for Signor Francesco Foscari, is an important design of type I on plan, with projecting Ionic portico, reached by an external flight of steps on each side. It is curious to observe that Palladio does not appear to mention this building in his work, yet Bertotti does not doubt that it is his. Temanza, in his "Life of the most celebrated Architects and Sculptors," published in 1778 at Venice, refers to this house as the work which brought our master to the notice of the Venetian nobility, and that it was the first executed in Venetian territory. Bertotti refers to the fact that it differs little from Palladio's design, although none appears in Leoni's edition. Internally it is very similar to others, and is of the usual three-storey type. The ground storey, forming the basement of the design, contains the kitchens, etc., and has an internal height of about eleven feet. The principal or first floor has, behind the projecting portico, the cruciform vaulted hall, half its length forming the height, and on each side of this hall is a set of three rooms, all of which are vaulted. The staircases are at the back, and the attic is utilized for granaries, etc.

House at St. Croce, near Padua, for Signor Nolin, is also of type I plan, and having the usual basement storey, principal floor ornamented with Ionic pilasters on pedestals, and attic over; while niches with statues ornament the wings. Although Temanza and "N. N." believe it to be genuine, Bertotti doubts its authenticity. 
A House at Vancimuglio, five miles from Vicenza, For the Conte Horatio Porto, is an almost exact counterpart in plan and elevation of the house at Malcontenta, with the exception of differently arranged staircases. Bertotti doubts the authenticity of this design.

The House at Stra, on the High Road Between Padua and Venice, for Signor Jacopo Foscarini, is of type 4 in plan, viz., a central block surrounded by quadrant colonnades. An external staircase leads, as usual, to the principal floor, in front of which is an external Ionic portico, with entablature and pediment over. The basement and attics are occupied as usual. 


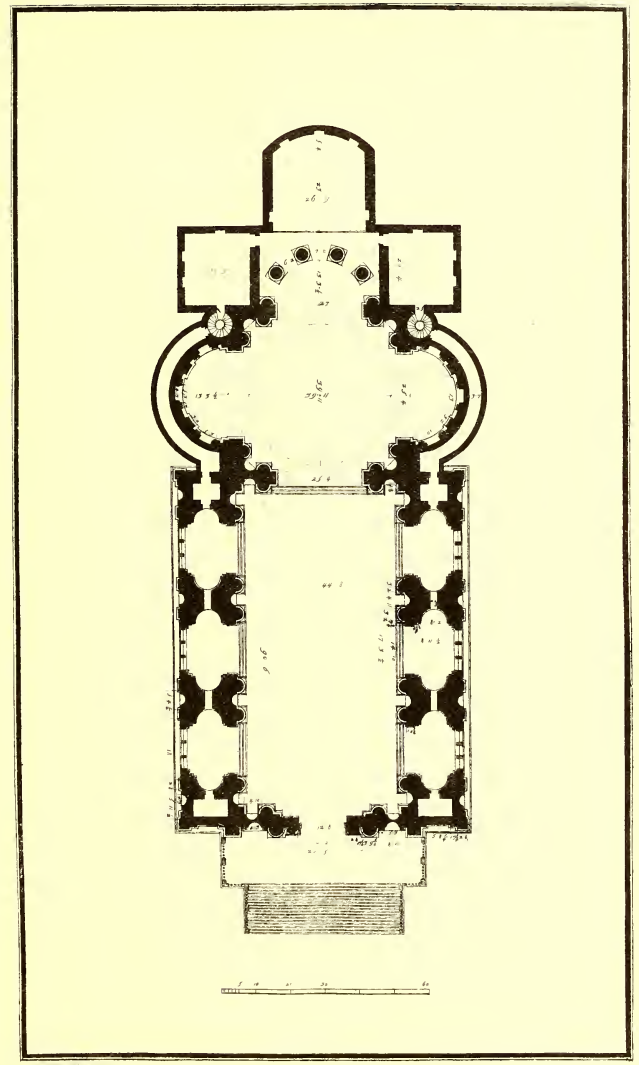

32. IL, REDENTORE, VENICE. PLAN. 



\section{CHAPTER VII}

\section{CHURCHES}

DALladio's studies of the ancient temples are evi1 denced in his Book IV., wherein he treats of those in Rome and others to be seen in Italy. In his preface to this particular book he dwells on the importance of buildings raised for devotional purposes, as follows :

"If labour and industry are to be laid out upon any fabric, to the end that in all its parts it should have the exactest symmetry and proportion, this, without the least doubt, is to be practised in those temples wherein the most gracious and all-powerful God, the Creator and giver of all things, ought to be adored by us; and in the best manner that our abilities may permit, be praised and thanked for such manifold favours as $\mathrm{He}$ continually bestows upon us. For if men, in the building of their own houses, use the utmost diligence to find out skilful and excellent architects, with other capable workmen, they are certainly obliged to be much more diligent in the building of churches; and if in the former their principal aim be convenience, so in the latter they ought to have a regard to the dignity and greatness of Him that in the same is to be invoked and worshipped."

In Chapter I. he discusses the situation chosen by the ancients for the temples to the various gods; in Chapter II. the various forms of temples, as circular, quadrangular, hexagonal, octagonal, cruciform, and refers to the fact that 
Vitruvius only discusses those of circular and quadrangular form.

He then speaks strongly in favour of the circular shape, because it is "alone among all figures simple, uniform, equal, strong and most capacious . . . the extreme in every part being equally distant from the centre; it is, therefore, the most proper figure to show the unity, infinite essence, uniformity and justice of God." The cruciform plan, as representing the cross on which the Saviour was crucified, is referred to as commendable by Palladio, who says, "In this form I built myself the church of S. Giorgio Maggiore in Venice."

Chapter III. treats of the seven different kinds of rectangular temples, according to the disposition of their columns, viz. :

I. In antis

2. Prostyle

3. Amphi-prostyle

Without porticoes.

4. Peripteral

5. Dipteral

6. Pseudodipteral

7. Hypaethral

Chapter IV. refers to the method of spacing the intercolumniations, viz. :

Pycnostyle, $\mathrm{I} \frac{\mathrm{I}}{2}$ diameter.

Systyle, 2 diameters.

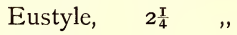

Diastyle, 3 ",

Araeostyle, more than 3 diameters.

Our master refers to the Eustyle treatment as the best.

In Chapter V. Palladio deals with the compartments of temples and the proportions used in the ancient examples, circular or quadrangular, and refers to the fact that the 


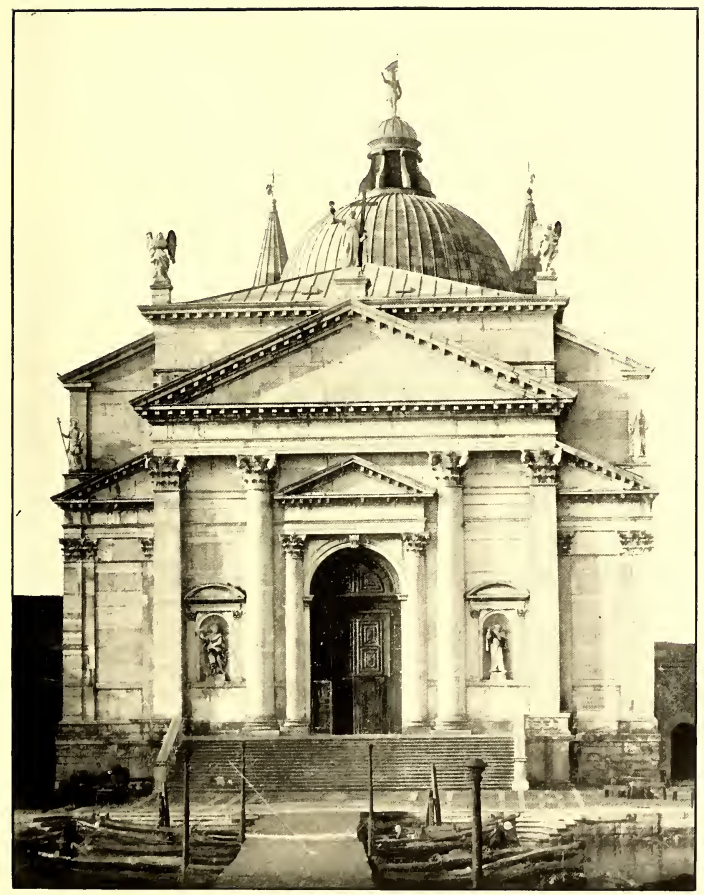

33. IL RENENTORE, VENICE. FRONT VIEW. 



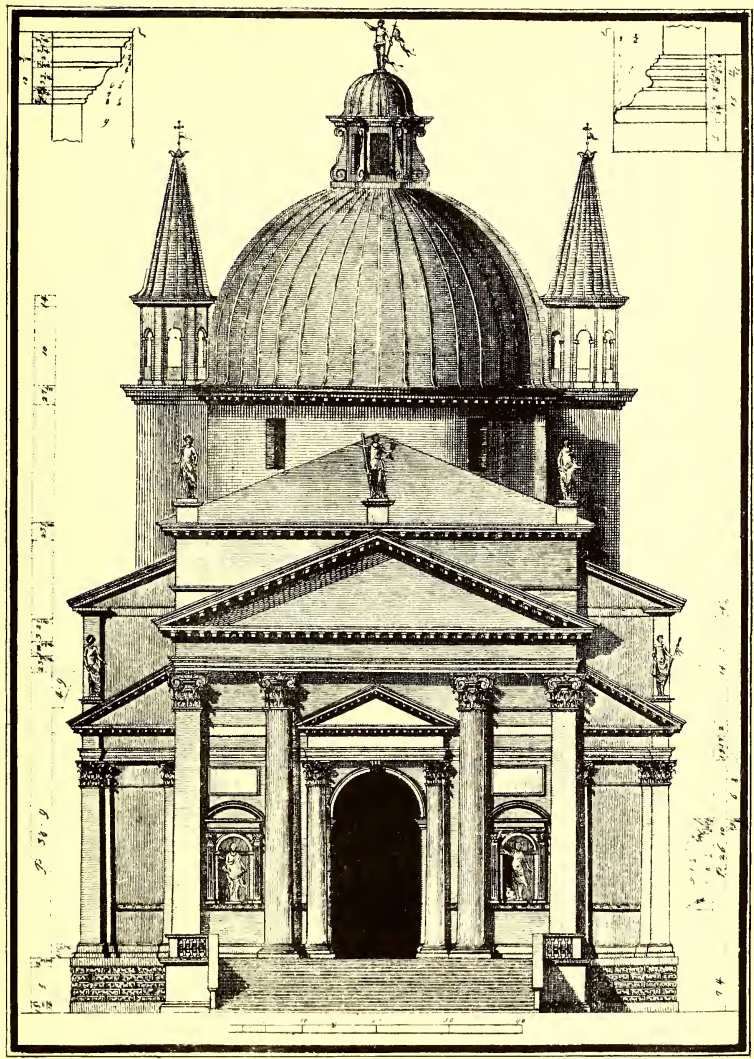

34. IL REDENTORE, VENICE.

FRONT ELEVATION. 



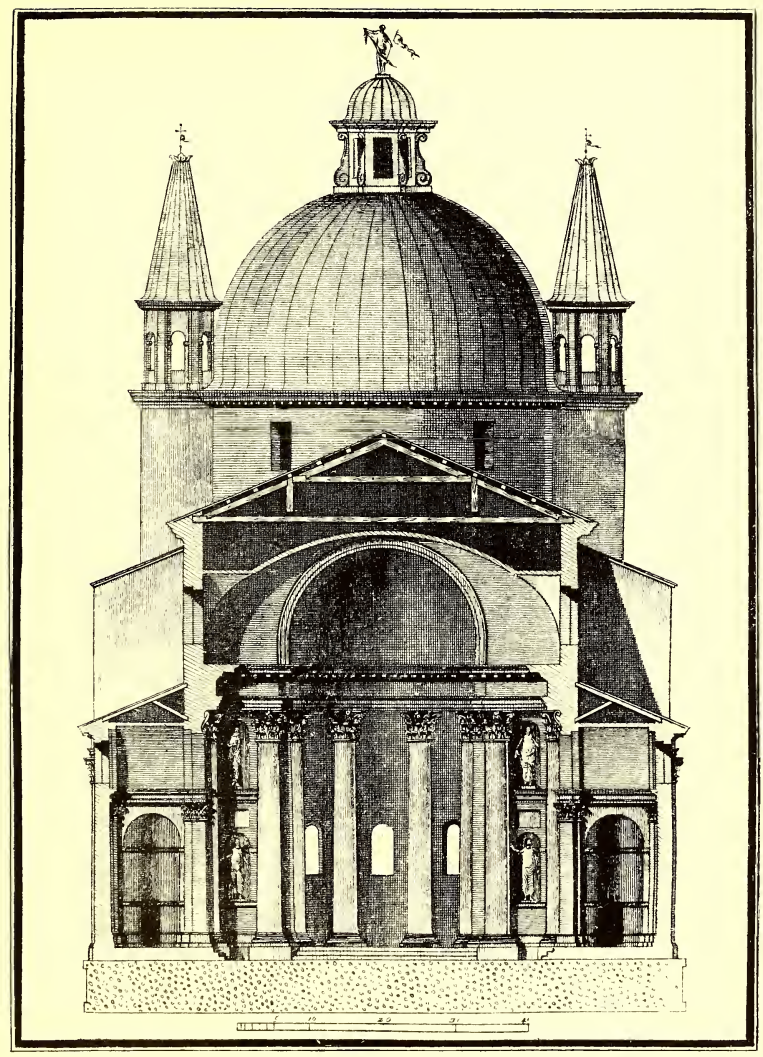

35. IL REDENTORE, VENICE.

SECTION. 

churches of his time were built very like the halls of justice or basilicas, in which the porticoes were placed inside the building, and he gives as his reason, "That the first who, being enlightened by the truth, embraced our religion, were accustomed for fear of the Gentiles to meet in the basilicas of private persons, where, observing afterwards that this form was very commodious, . . . they have not thought fit to change it since."

To this basilican plan he says there is added "the sacristy or vestry . . . and then towers and steeples, in which bells are hung to call the people to divine offices."

The remaining chapters in this book describe the several ancient temples in Rome, Italy and elsewhere which Palladio had assiduously measured.

The churches which he was called upon to design were mostly at Venice, and we will describe each in turn.

Il Redentore, Venice (Plates 32, 33, 34 and 35).This church, situated on the island of La Giudecca, was built at the expense of the Republic of Venice, and consecrated to the Redeemer for the deliverance of the city from the plague which ravaged the town in 1576. Palladio's instructions seem to have been to design a church which should represent expressly the devotional idea, and which probably induced him to provide a number of chapels. On reference to the plan it will be seen that it is in the form of a Latin cross, in the long arm of which are three chapels formed in the aisles on each side of the nave, which is twice its width in length. A dome crowns the crossing, supported on the four arches defining the nave and aisles, and having its base brought to a circle by pendentives. The height of the dome from the ground is $21^{\frac{7}{2}}$ times the width of the base. The sanctuary, at the south end of the 
building, has a semicircular screen of Corinthian columns and contains the principal altar, while the transepts are also of semicircular form. Behind the screen is placed the choir, severely plain, agreeing in treatment with Capuchin ideas. The walls of the interior are ornamented by an order of Corinthian half columns, $1 \mathrm{O}_{4}^{\mathrm{I}}$ diameters in height and with entablature one-fifth of their height ; these columns are coupled between the chapels and have two niches between them. The arches to the side chapels are semicircular and rest upon impost mouldings supported by Corinthian pilasters. The height of these openings is rather more than twice their width. Each chapel is crowned with an internal semicircular vault, corresponding with the arch to the nave. The height of the nave vault, which is of brickwork, and rises from the main entablature is 65 feet Io inches, and in this semi-elliptical vault are semicircular arches lighting the nave. Arches of this form are also placed lower in the chapel aisle walls in order to light these portions.

The façade has a main order of Composite columns, expressing the interior nave; the inner ones are half columns, the angle ones are pilasters $1 \mathrm{O}_{2}^{\mathrm{I}}$ diameters high, and support an entablature one-fifth of the column in height, over which is a pediment. The pilasters throughout are diminished, and have an entasis in the same manner as the columns. This order is raised upon a stylobate, in the height of which is managed the principal flight of steps, which is as wide as the nave on plan. On either side of the central space the side chapels are designed as wings, ornamented with Corinthian pilasters springing from the same level as the principal order. Half columns of this same order flank the central door of the church and support entablature and pediment, and are also carried round the lateral façades. 


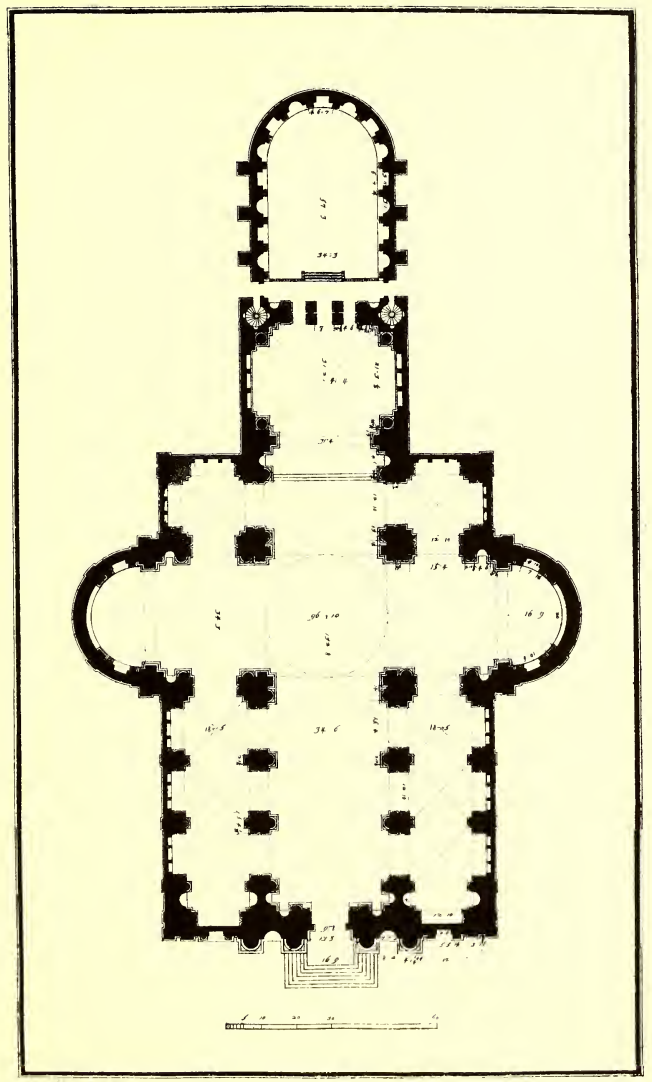

36. S. GIORGIO MAGGIORE, VENICE.

I1, IN. 



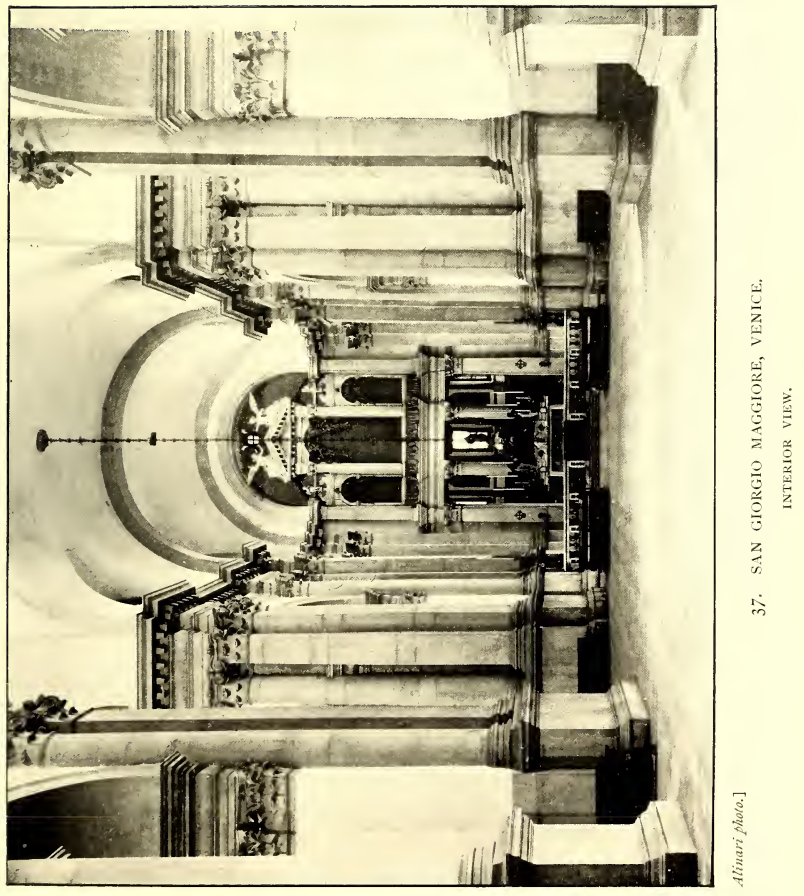





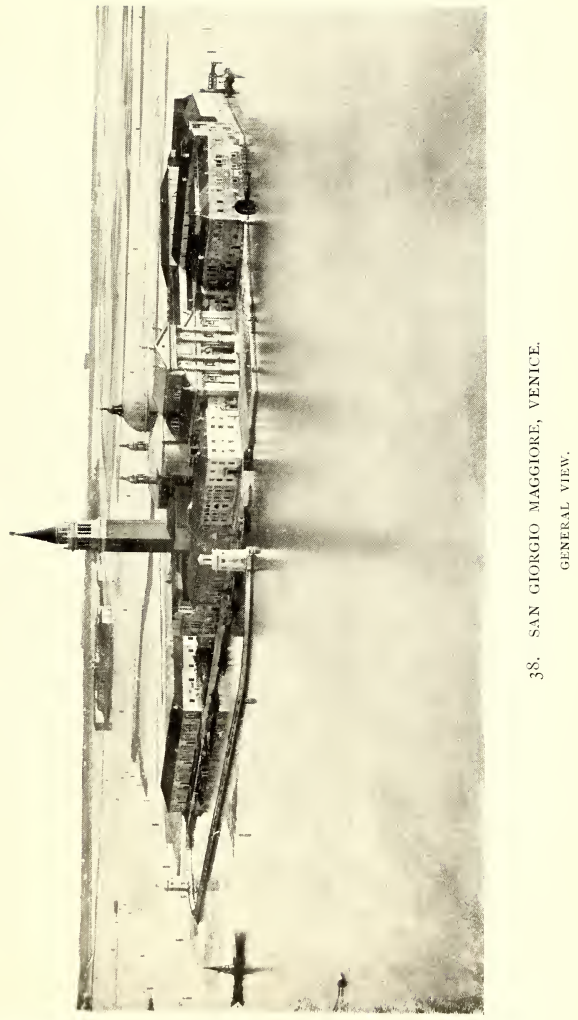



On either side of the central doorway are niches for statues, flanked by pilasters supporting entablature and pediment. The central part of the façade is 63 feet wide and 75 feet high. The walls, vaults, chapels, leaves of capitals and interior dome are of brick, while the bases, imposts, entablature, dressings to windows and doors, and the façade are of Istrian stone. Above the walls separating the side chapels are taken masses of masonry, forming buttresses to resist the pressure of the nave vault. The comparison of this façade with that of S. Giorgio Maggiore is interesting.

S. Giorgio MagGiore (Plates 36, 37 and 38).-The plan differs principally in the side aisles, these taking the place of the side chapels in Il Redentore. The church is dated 1556 , and the façade 16ı. A different treatment of the sanctuary is also adopted. S. Giorgio Maggiore was the first church which Palladio erected in the capital of the Venetian state. It belonged originally to the Benedictines and was attached to their monastery. It owes its picturesqueness largely to its position on an island of its own name, facing the eastern end of the Grand Canal, opposite the Piazza of St. Mark, from which a splendid view of it is obtained. The plan is cruciform, consisting of a nave 40 feet in width, and aisles about half that width. The length of the nave up to the crossing is about twice its width. The transepts have semicircular ends, and over the crossing is a dome constructed internally of brick and externally of timber and lead. One bay beyond the crossing is planned similarly to the nave, and at this point the aisles are stopped, and the sanctuary and chapter-house are continued without aisles, being raised three steps. The chapter-house is richly decorated with niches, statues and other ornamentation. In 
the interior a Composite order of columns and pilasters $10 \mathrm{~T}$ diameters in height, placed on pedestals, a quarter of the column in height, ornament the walls, these columns not being coupled as in Il Redentore (Plate 36).

Between the nave columns are semicircular arches, resting on the entablature of the smaller coupled Corinthian pilasters without pedestals. The soffit of these arches which extends over the width of two pilasters is of considerable depth, and has a much bolder and better appearance than the thin arch in Il Redentore.

The proportion of the nave arcades is somewhat lofty, the opening being $2 \frac{\mathrm{T}}{2}$ times the width. A brick vault of semicircular outline, stilted above the springing, crowns the nave. Its height above the floor is 70 feet. The external façade is of a very similar type to that of Il Redentore, but a better proportion is obtained by raising the principal order on a pedestal and designing the minor order without one.

The main order is Composite, resting on pedestals, which in their turn are placed upon a plinth about 3 feet in height. The seven steps at the entrance to the church are formed in the depth of this plinth. The central portion of the façade has four half columns supporting entablature and pediment crowned with statuary. The pedestals are one-third the height of the columns, which have ro diameters. The smaller Corinthian order which, as pilasters, decorates the aisles supports half pediments on each wing. In the centre of each on the main façade are niches filled with urns and with busts of eminent senators, flanked by pilasters with pediments. The central doorway is only open up to the impost ; the semicircular portion being left solid. According to Temanza, this façade was added by the architect Scamozzi. He also informs us that the interior of the church was completed in I 579, the choir and the façade being still unfinished. 


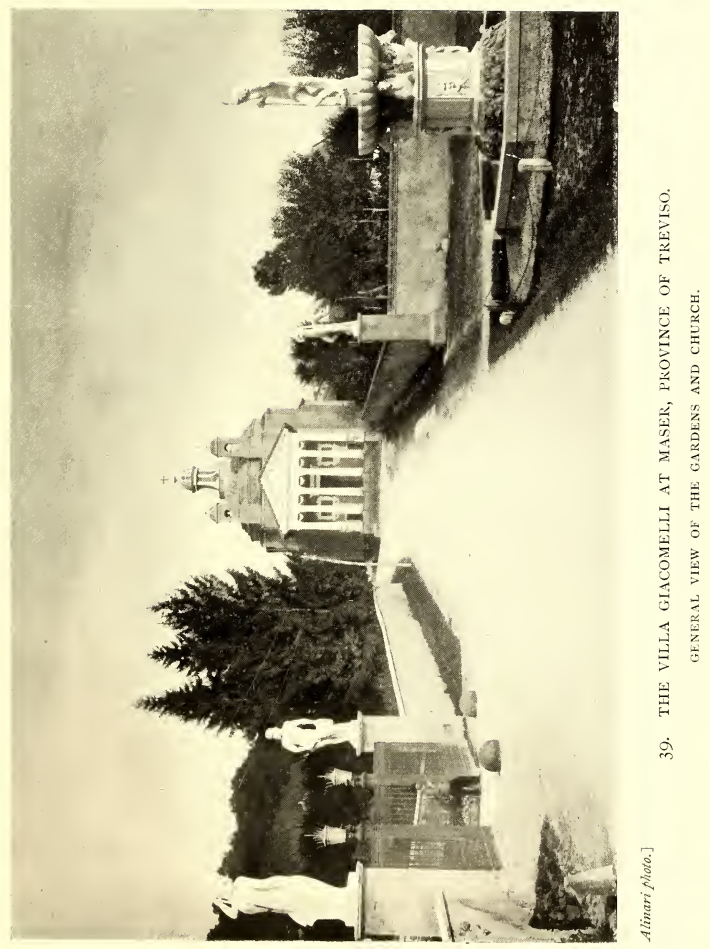



Palladio died in the following year, and the façade was completed at the commencement of the seventeenth century.

Church at Maser (Plates 39, 40).-This little church is isolated in position at the end of a long road. The plan differs from those of the larger churches already described at Venice. It is circular, having an internal diameter of 40 feet, and is of the type Palladio admires and describes in his Book IV., Chapter II.

A wide flight of steps leads to a projecting portico of the Corinthian order, with two lateral arches and a central doorway leading into the church. The length of this portico is nearly two-thirds of the diameter of the church, and Palladio has followed the same proportions as in the Pantheon at Rome, which of course had been measured by him, and whose portico has in length two-thirds of the diameter of the interior. The width of the portico in regard to length is as two to five, as at the Pantheon.

The interior circumference of the church has eight Corinthian half columns, 2 feet 3 inches in diameter, supporting an entablature and gallery, which is reached by the smaller circular staircases from the portico. A dome crowns the whole, light being admitted through a somewhat high lantern. From the central space three recesses branch off, the fourth being the entrance. These are crowned by semicircular vaults, are occupied by altars, and their segmental walls are struck from the same centre as the central portion. In the four other intercolumniations are niches flanked by pilasters and crowned with pediments. The height of the interior of the church is to the diameter as six is to five. The exterior façade (Plate 40) has a hexagonal portico of Corinthian columns 2 feet in diameter, and it is peculiar that only the four centre columns are circular, the outer ones 
being square on plan. The inter-columniation varies from $I \frac{1}{2}$ to $I_{4}^{3}$ diameters. The columns support an entablature and richly sculptured pediment. The length of portico is equal to the height, excluding pediment but including steps. Including the pediment the width is to the height as six is to seven. The stylobate is in height a quarter of the columns. Plate 40 shows the festoons suspended between the capitals, a feature condemned by many critics. The two small bell turrets on either side crown the small staircase.

Church of S. Lucia at Venice.-An inscription on. this church informs us that it was the work of Palladio, but according to Temanza a large part of it was finished after his death, including probably the façade, which Bertotti, however, thinks was part of an older building.

In plan it is nearly square and is divided in three, the transverse width being 44 feet 6 inches and the length 77 feet. The interior has two orders, one over the other, the lower one Ionic and the upper Corinthian, a quarter less in height. Over the entrance aisle is the choir of the nuns.

Church of Le Zitelle at Venice.-This little church is situated near Il Redentore on the island of $\mathrm{La}$ Giudecca, and according to Bertotti the design is attributed to Palladio, but Temanza is of opinion that other architects were employed upon it.

In plan it differs from the above-named churches, having a square interior with the angles cut off, in order, according to Temanza, to render the circular dome, which is of brick, easier of construction. Light is introduced by a lantern above the dome. The interior has Corinthian pilasters resting on a continuous pedestal, a quarter of the height of the columns, while the cornices have modillions in two 


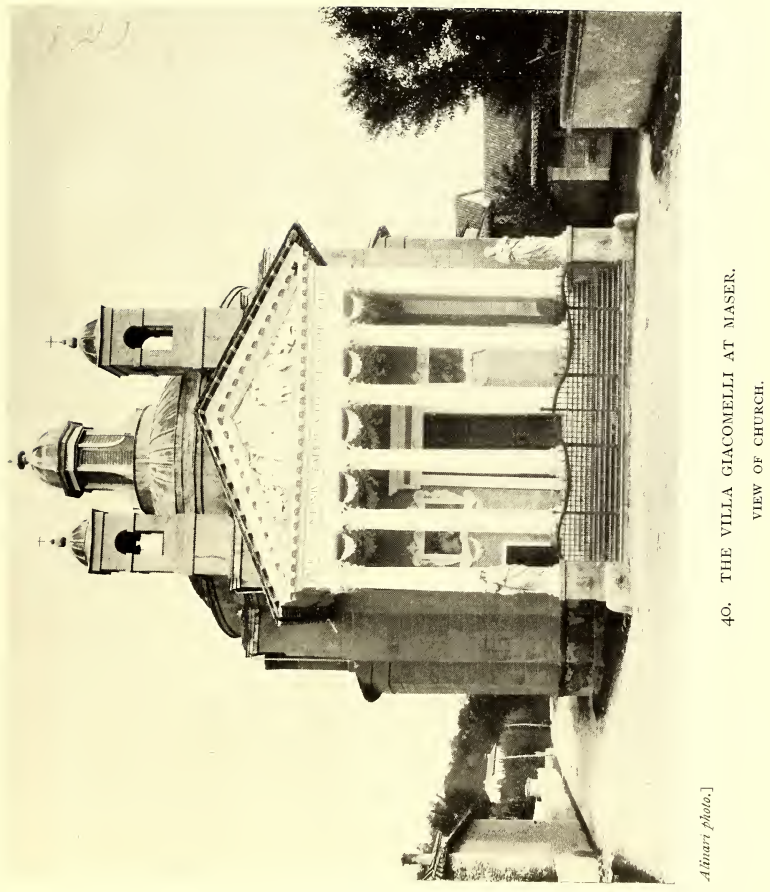



faces, a feature usually reserved for the Composite order. Opposite the entrance is a square recess containing the principal altar.

The façade is a very weak composition and may have been added later, as was the custom with so many other churches. It has two orders of Corinthian pilasters, one above the other; coupled at the angles of the façade and leaving a large central space, occupied in the lower portion by a central door with windows on either side, and in the upper part by a large semicircular window. The whole façade is crowned by a single pediment.

Façade of S. Francesca della Vigna, Venice.The interior of this church was erected from the designs of Sansovino in 1534 . After his death Monsignore Giovanni Grimani obtained a design for the façade from Palladio, and it is related that Sansovino's design was rejected for that of Palladio. It would be interesting to see Sansovino's design, but it is not given by Bertotti. The façade (erected in I562), bears a remarkable resemblance to that of S. Giorgio Maggiore, to which it may be compared, but to which it is inferior, especially as it repeats the defect of interrupting the stylobate, by cutting the principal doorway through it, a much better treatment being adopted at Il Redentore. Another fault is in the management of the orders, for too great a contrast is obtained by starting both the principal and subsidiary order from the same base, the treatment at S. Giorgio being preferable. Four Corinthian half columns placed upon projecting pedestals, and crowned by an entablature and pediment, form the central feature of the façade. An inferior order of these columns starts from the same level, on a continuous base and ornaments the sides of the main doorways and the window openings. The entablature to 
this secondary order is stopped where it meets the main order of columns, whose shafts it would otherwise cross. The central doorway with semicircular head has a height of three times its width, the arched portion being filled in with sculptured stonework, as at S. Giorgio.

Design for the Façade of the Church of $\mathrm{S}$. Petronio at Bologna (Plates 4 I and 42). -The churches already described were erected from Palladio's designs, but we cannot leave the subject of our master's church architecture without referring to the designs he prepared for the finishing of the above façade. These were not carried out, but they are interesting as showing the treatment he proposed as a frontispiece for a Gothic church. Other architects also furnished designs, as may be seen in the workshop at the end of the north aisle in the church, which contains some forty sketches relating to this façade, dating from the fifteenth to the seventeenth century. These are by Giulio Romano (a pupil of Raphael), Palladio, Vignola and others. Bertotti describes how thirty-five architects in all were consulted during the progress of the church, and how it was decided to raise the height of the interior from I I4 feet to I 20 feet. In the workshop already referred to is also to be seen a model of the church in wood.

It was commenced in 1390 , in emulation of the Cathedral at Florence. Some idea of its size can be imagined when we find that its area, if completed, would have rivalled St. Peter at Rome. Only about a third of the design has been carried out and the façade has remained uncompleted. Palladio prepared five designs for it, three being I I 4 feet in height, and the fourth 120 feet. In two of these designs a single Corinthian order of two dimensions is employed, resting on pedestals of different height in each design. The 


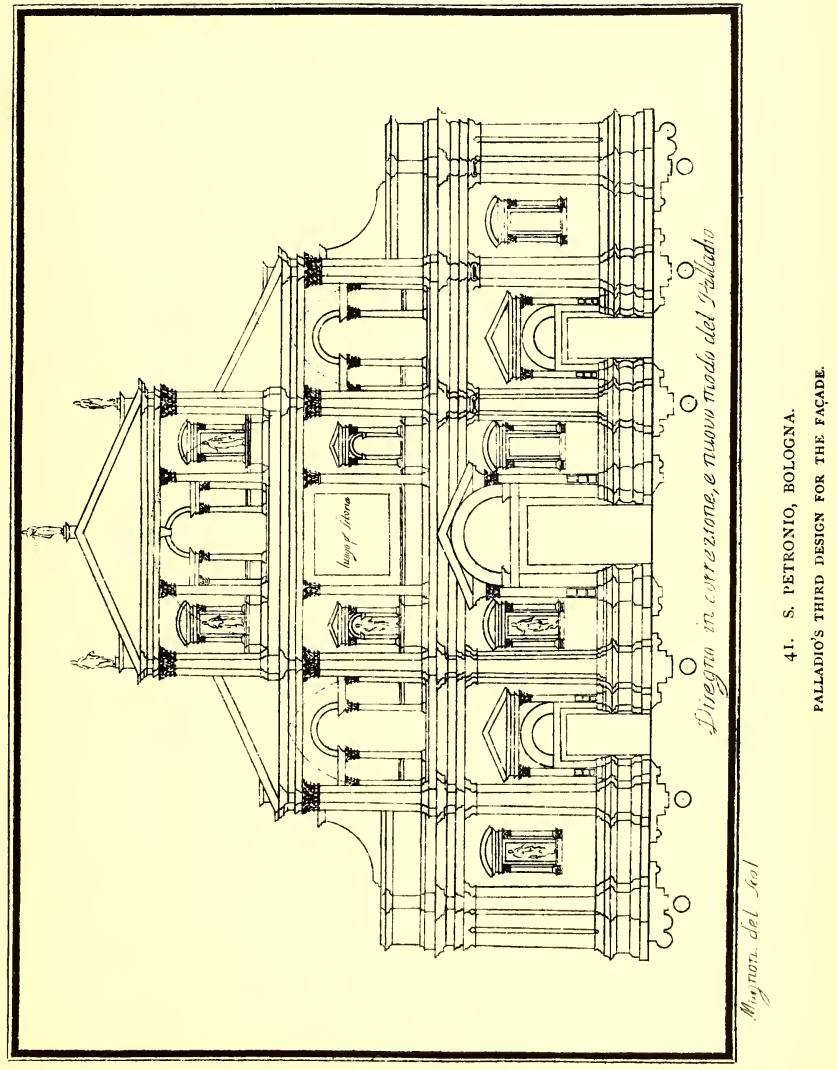



height of the column is the same in each case, the entablature and pedestals being varied in position. The entablatures of the smaller order are carried through between the main columns. We can see traces of his endeavour to produce a similar treatment to that of his Venetian churches, especially to that of S. Francesca della Vigna, but in this case he had to deal with an interior of five divisions, consisting of a central nave, two aisles, beyond which, on each side, extended a series of chapels. Palladio has indicated these divisions in all his designs for this façade. The design No. 2 has an attic of small pilasters, in front of which are statues, crowned by a pediment. In design No. I the pediment starts from the main cornice and an attic is placed over this.

The difficulty Palladio was contending with was the application of a classic façade to a Gothic structure. In the former breadth and not height is the chief characteristic. Both of these designs suffer from having the stylobate of the main order pierced for the central doorway. Palladio's third design (Plate 4I) was due to instructions to preserve certain features already existing in the façade, of which the principal doorway appears to have been one.

In consequence, the main cornice of the lower order is broken by the pediment of this doorway. In this design our master has divided the height into three orders: the lower one he intended to be either Doric or Ionic, as shown on either side of the centre, and it was to extend the whole width of nave, aisles and chapels. The two upper storeys are of the Corinthian order, considerably less in height. The intermediate order extends over the nave and aisles only, having half pediments over the latter. The upper storey indicates the nave only and is crowned with a pediment. The whole façade is covered with pedimented niches, giving 
a rich appearance, but with less dignity than either of the two previous designs. The fourth design (Plate 42) is of similar treatment, and it is evident that in this design Palladio was obliged to preserve all the Gothic features in the façade which influenced, to a certain extent, design No. 3 . Both Conte Algarotti and Temanza are of this opinion, and the latter, in his life of Palladio, distinctly states this as his opinion, and refers to the fact that in this fourth design, "mixed with the Gothic or German and the Roman or Greek style," the Gothic only exists in the lower storey, " among architectural features of better taste which have no connection with them." He also says that, "doubtless the architect has been obliged to include the old ornamentation of the doorway and of the wings to the old façade," certainly shown in this design, which is similar, as to the upper storeys, to design No. 3, but on the lower storey has Corinthian pilasters of attenuated proportion, and a Gothiclooking entablature, the old lines of the Gothic building being kept. The upper parts of the three doorways to the lower storey are an attempt to mingle the two styles.

The columns or pilasters throughout this façade are more attenuated than is usual with Palladio. Bertotti refers with praise to "the skill with which Palladio knew how to combine ingeniously the Gothic and the Roman style," but others will doubtless be glad that such a jumble was never put into execution. There appear to be some doubts about the authenticity of this design, but Conte Algarotti does not doubt it, and recognizes in particular Palladio's handwriting, which accords with that in the BurlingtonDevonshire Collection of Drawings (now in the R.I.B.A. Library). ${ }^{1}$ He also finds similarity in the marginal notes in 


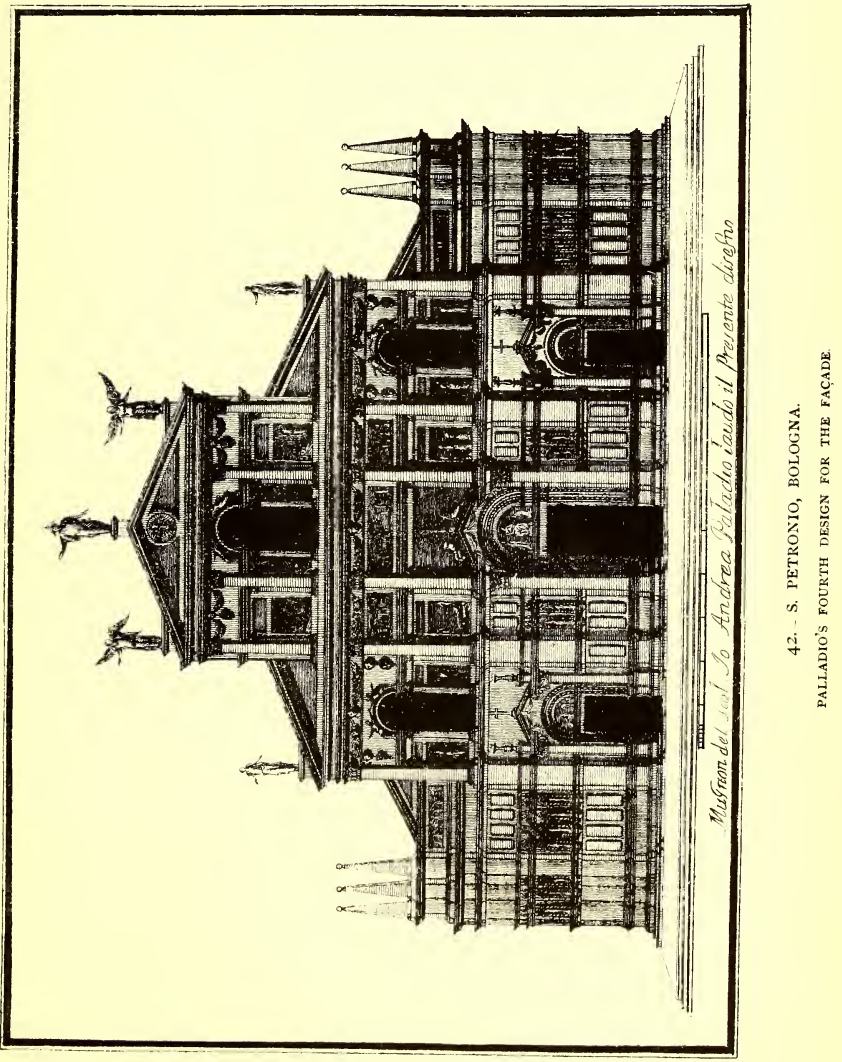



the Vicentine dialect, and in the method of drawing the statuary and sculpture.

Convent of La Carità at Venice (now the Accademia delle Belle Arti).-Palladio publishes this design as an illustration to Chapter VI. of his second book. A part of the design was executed during his lifetime, but a fire afterwards destroyed a large portion. The plan published from measurements by Bertotti shows an outer atrium 60 feet long by $45 \frac{1}{2}$ feet wide, of Composite columns, two storeys in height, from which is reached the cloister court, 86 feet by 70 feet.

The vestibule or atrium has eight isolated Composite columns 40 feet in height. The design shows this atrium lit by a central quadrangular opening. On each side of the atrium are square rooms appropriated to the sacristy and chapter house. The cloister court is surrounded by three storeys of arcades ornamented with the Doric, Ionic and Corinthian orders. The two lower storeys are arched between these, the upper one being walled in and provided with windows. The Doric order has not the usual triglyph in the frieze. Bertotti mentions this as showing the good taste of our master, because there are no beams to express, the floor behind being supported on arches. The Ionic order of this court has columns one-seventh less in height than the Doric. As in so many of Palladio's buildings, brick is the chief material employed. It is covered with stucco, the bases, capitals of columns and upper parts of cornices being in stone.

It is generally believed that Inigo Jones utilized the design of this building in Houghton Hall, Bedfordshire (now in ruins, being dismantled in I794).

The centre of the north front of Houghton Hall is held 
to have been similar to the courtyard of Palladio's building, the principal feature being a recessed portico, about 22 feet by I 2 feet, with four Doric three-quarter columns; above are the remains of an open Ionic loggia, a feature then new to England, but a favourite treatment of Inigo Jones, and used also at the Queen's House, Greenwich, and elsewhere.

Altar in the Hospital of S. Spirito, Rome.Letarouilly, " Rome Moderne," quarto, Paris, I840, mentions that Palladio erected an altar in the above hospital, while measuring in Rome, and that this was his only production in that city. 


\section{CHAPTER VIII}

\section{LITERARY WORKS AND DRAWINGS}

DALLADIO had apparently early in his career a love for classical literature, and was much influenced by Vitruvius's great work on architecture. He followed his great master in writing down his ideas and principles for the benefit of the architects of his own day and for those in posterity. He commenced with the "Antiquities of Rome," first published in Venice in I554. His principal work was his "Treatise on Architecture," published in four books, of which countless editions have been published, and which has been translated into every European language. The various editions are as far as possible mentioned in the bibliography. The best edition for English readers is undoubtedly that issued in 1742 (third edition, corrected) by Giacomo Leoni, a Venetian, and architect to his most serene highness, the late Elector Palatine.

It is translated into English, and is further of very great interest because it contains the notes and remarks of the great English architect, Inigo Jones, taken from his original manuscript in Worcester College Library, Oxford. This edition was published in two volumes.

Inigo Jones's copy of Palladio's "Architecture" came into the possession of one Dr. Clarke, member of Parliament for the University of Oxford, and he bequeathed it to Worcester College, the authorities of which institution gave permission for the notes made on the plates by Inigo Jones 
to be copied. Giacomo Leoni was commissioned to copy these notes in I74I, some of which are placed in the side margin and the rest (which make several sheets), are added at the end of each book.

It will be of little use to do more than mention the main divisions into which Palladio has divided his great work. In the Preface he says, "My natural inclination leading me, from my very Infancy, to the study of architecture, I resolv'd to apply myself to it: and because I ever was of opinion that the ancient Romans did far exceed all that have come after them, as in many other things so particularly in Building, I proposed to myself Vitruvius both as my master and guide, he being the only ancient author that remains extant on this subject."

This statement is interesting as it indicates that from the first he fell very much under the influence of Vitruvius, whose rules and instructions he followed very largely. Palladio then relates how he journeyed to different parts of Italy, measuring up the remains of Roman architecture and studying and comparing in the same manner as the modern architectural student. He was also indebted to Leo Baptista Alberti and "other excellent writers." He then proceeds: "I thought it an undertaking worthy of a man who considers that he was not born for himself only, but likewise for the good of others, to publish to the world the Designs (or Draughts) of those edifices, which with equal expense of Time and Danger of my Person, I have collected and briefly to set down what seem'd to me most worthy to be consider'd in them," etc., etc.

After referring to those artists honourably mentioned in the books of that "rare Painter and Architect," George Vasari, he mentions that Venice afforded an example of the grandeur and magnificence of the Romans "since that celebrated 


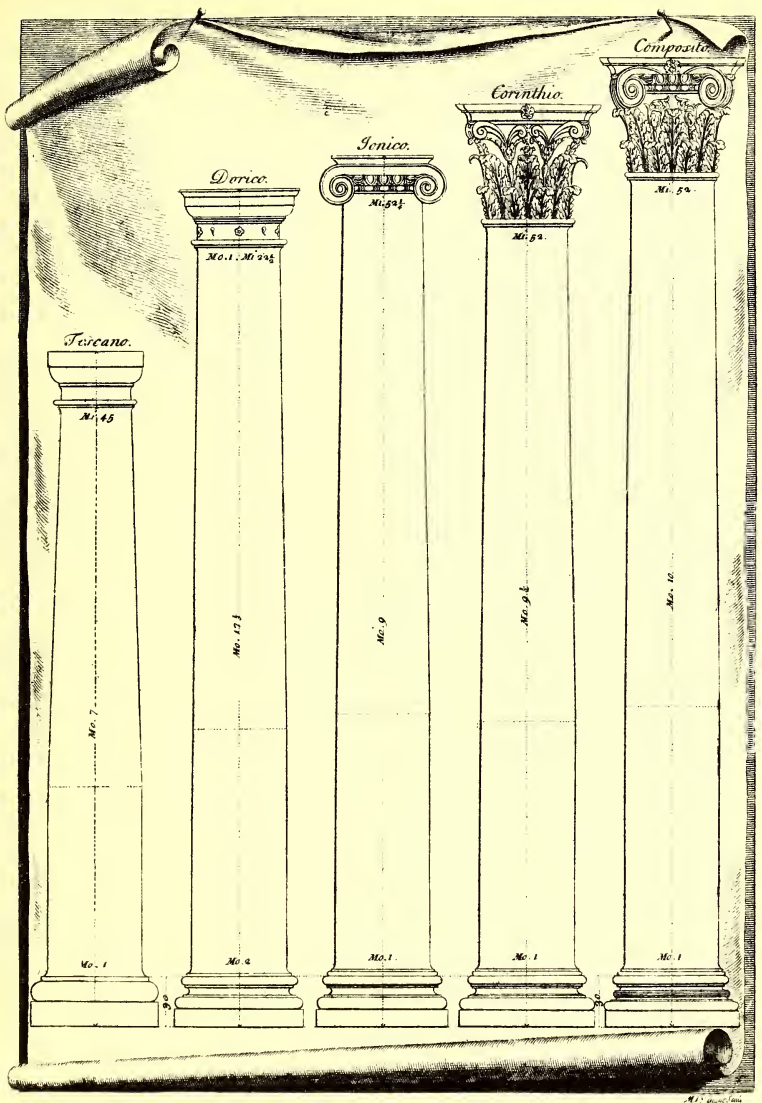

43. THE FIVE ORIERS OF ARCHITECTURE AFTER PALLADIO.

GENERAL PROPORTIONS. 

carver and architect, Giacomo Sansovino, first introduced the true manner" (the renaissance of classic forms). Reference is then made to his own native town of Vicenza, where "I had first occasion to put that in practice which I now publish for the common good." In connection with Vicenza he refers to his principal clients, and finishes his Preface by a short statement of the reasons why he divided his book into the several parts.

Book I. contains articles on building materials generally, such as timber, stones, sand, limes and metals etc., with back references to Vitruvius; chapters on foundations, walls, on the five orders of architecture (Tuscan, Doric, Ionic, Corinthian and Composite), and their proportions, pilasters, pedestals, floors, ceilings, the height of rooms, arches, doors, windows (and their ornamentation), chimneys, staircases and roofs. Side-notes by Inigo Jones help to elucidate the text and to give additional information thereto, and Jones's notes are also placed at the end of the chapter and refer to the observations he made when travelling through Italy.

Chapter XIII. refers to the diminution of the shafts of columns and of the entasis which should be given to them.

The Proportions of the Orders according to PalLADIO.-The major part of Book I. refers to the proportions and ornamentations of the orders and their entablatures, and illustrations of many of these are given here.

Plate 43 shows the proportions of the five orders of architecture according to Palladio. As to the entasis which should be given to the shafts, Palladio says: "I divide the shaft of the column into three equal parts, drawing the lower third part perpendicular, at the extremity of which I lay a thin bending Rule as long as the column, or a little more; and bending that part of the Rule till the end touches 
at the point of the diminution under the Astragal, I follow the bent of the Rule, and so the column becomes somewhat swelled in the middle, and diminishes towards the top very handsomely." This method, it is interesting to know, is followed nowadays by masons. The various intercolumniations are then referred to, also the fact that in the front of buildings the columns should be of an even number, so as to allow of a central opening.

Our author then refers to the fact that the module is the diameter of the column taken at the base, and that he divides this module into sixty parts or minutes except in the Doric, in which the module is half the diameter of the column at its base. The comparative plate of the orders shows the proportions of the Tuscan order, and in this our author follows Vitruvius (Plate 43).

The Doric Order.-We give two plates showing Palladio's proportions of this order (Plates 44 and 45).

In the case of their employment without intervening arches, they should have an intercolumniation of not less than 3 diameters of the column, a spacing which is called diastyle by Vitruvius.

The module in this and in the Ionic, Corinthian and Composite orders is taken as the half diameter, which is divided in to thirty parts or minutes.

Plate 45 shows the order as a half column attached to a wall in which are semicircular arches, and Plate 44 shows a detail of the capital and entablature.

The Ionic Order. - We give four plates from our author's book. Plate 46 shows the column and entablature in its general proportions; the column is 9 diameters in height, and the entablature is one-fifth part of the height of the column. The intercolumniation is $2 \frac{1}{4}$ diameters called eustyle by Vitruvius. 


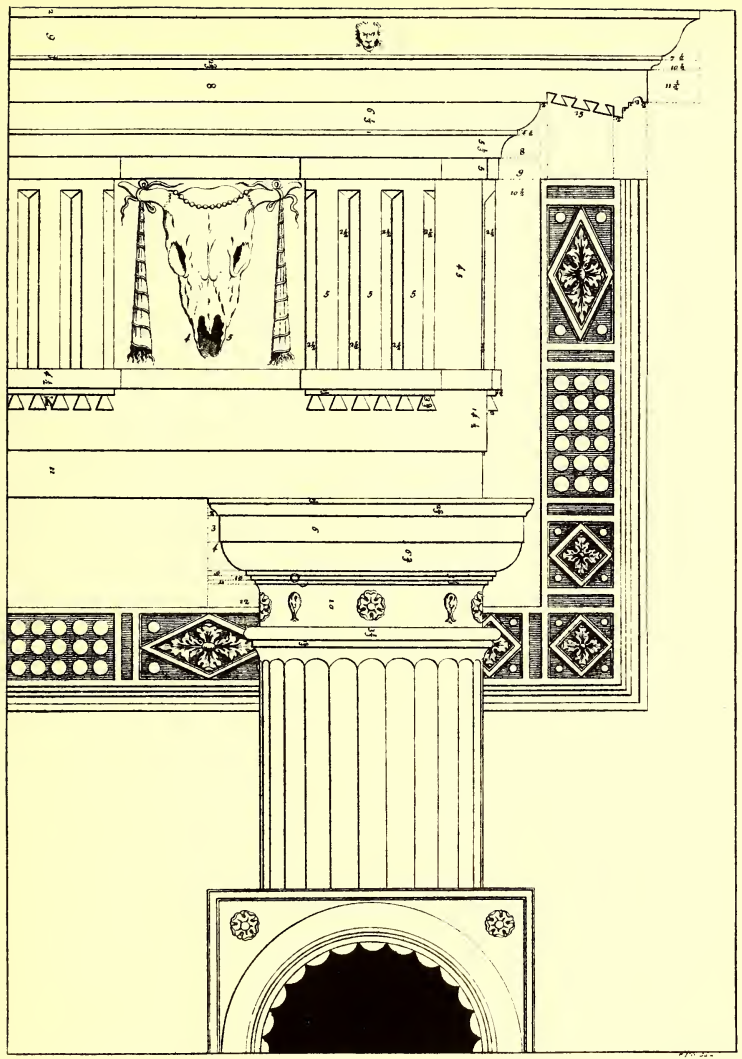

44. THE DORIC ORDER.

PROPOKTIONS OF CAPITAL AND ENTABLATURE. 



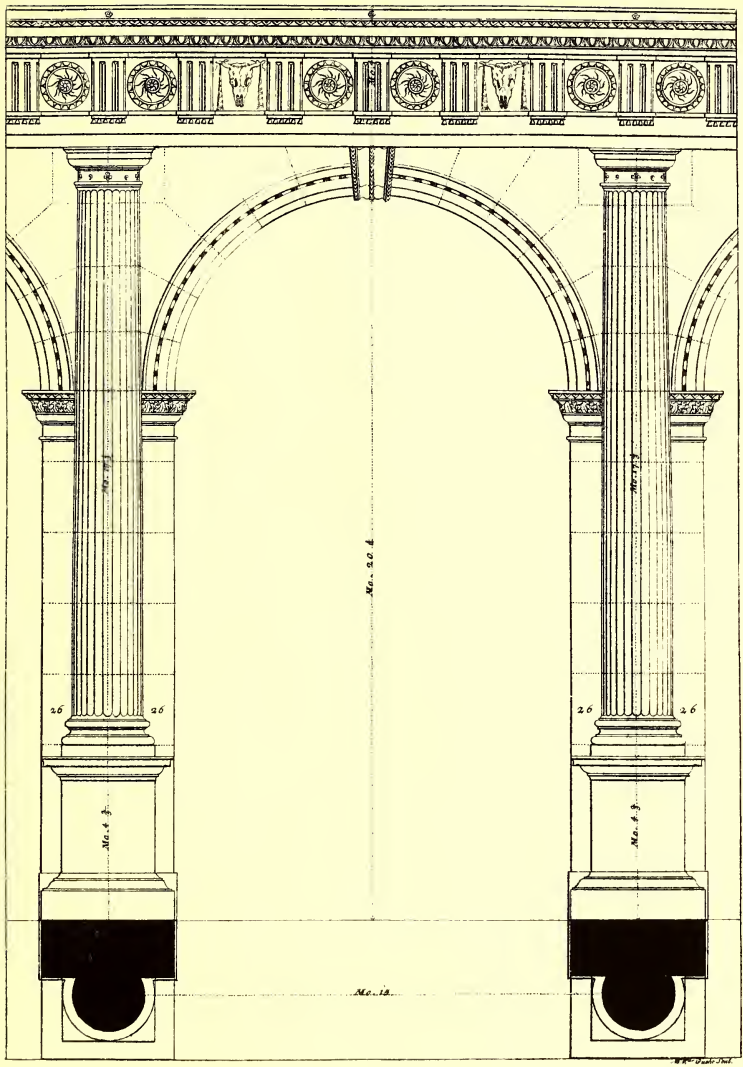

45. TIIE DORIC ORDER.

ARCADE WITH HALF COLUMN ON PEDESTALS. 

Plate 47 shows attached Ionic half columns backing on to piers, which are a third part of the width of the opening.

Plate 48 shows in detail the Ionic capital both in plan and elevation, and the proportion it bears to the rest of the column.

The method of striking the volute is indicated by the square formed in the eye of the same, showing the points whereon the fixed foot of the compass is to stand to make the volute. The treatment of angle capitals is referred in Palladio's fourth book, that is the book dealing with temples.

Plate 49 gives in detail the proportions of the Ionic column and its entablature.

The Corinthian Order.-Plate 5o shows that the height, according to Palladio, should be $9 \frac{1}{2}$ diameters including the base and capital; the column has 24 flutes, and the entablature is one-fifth part of the height of the column. The plate shows an intercolumniation of two diameters, as at the Rotonda at Rome, a method of spacing which is called systyle.

Plate $5 \mathrm{I}$ shows the treatment of the Corinthian order when used in conjunction with an arcade. In this the piers have two-fifths of the width of the archway, which itself is $2 \frac{1}{2}$ times its width in height.

Plate 52 shows in detail the pedestal which should be used with the Corinthian column, which is a quarter of its height, and it also shows the impost upon which the arch mouldings rest in an arcade.

Plate 53 gives in detail the Corinthian capital and its entablature.

The capital is $I_{\frac{1}{6}}$ diameter in height, and the plan shows the arrangement of the two tiers of acanthus leaves, eight in each tier, and the method of forming the volutes 
supporting the curved abacus (see plan), and the leaves out of which they spring. The entablature is designed to be one-fifth part of the height of the column.

The arrangement adopted in setting out the capital, including the projection given to the leaves, is indicated in the right side of this plate, and the arrangement and proportion of consoles and sunk coffering between the same, are very clearly marked on the plan looking up.

Plate 54 shows the Composite order (also, as Palladio remarks, named Roman) as being an invention of the ancient Romans.

Our author remarks that it is called Composite because it is composed of the Ionic and Corinthian capitals ; it is more slender than the Corinthian, to which however it has a general resemblance.

The column is here figured as ro diameters in height, and the intercolumniation is shown as $I_{2}^{\frac{1}{2}}$ diameter, or picnostyle, as Vitruvius calls it.

Plate 55 shows this column attached to arcades; the piers are about half the width of the openings, which have a height of $2 \frac{1}{2}$ times their width. The pedestal is shown as one-third the height of the column.

Plate 56 shows in detail a capital and the entablature of this order, from which the difference between it and the Corinthian capital can be at once seen.

The upper part of the capital is of the angular Ionic type, and the lower part has the two rows of acanthus leaves The entablature is one-fifth the height of the column, and varies from the Corinthian principally in the consoles of the cornice and in the omission of dentils, and in having a pulvinated frieze.

In his first book Palladio promises a treatise on fortifications both of cities and harbours, but this was not destined 

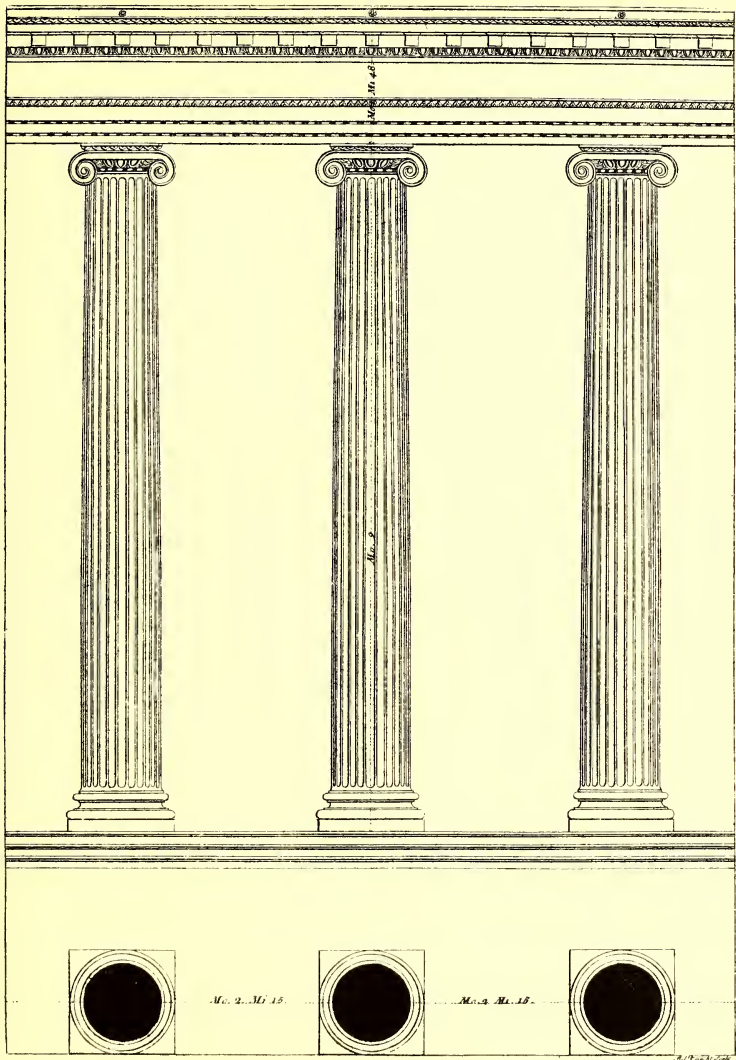

46. THE IONIC ORDER.

GENERAL PROPORTIONS OF A COLONNADE. 



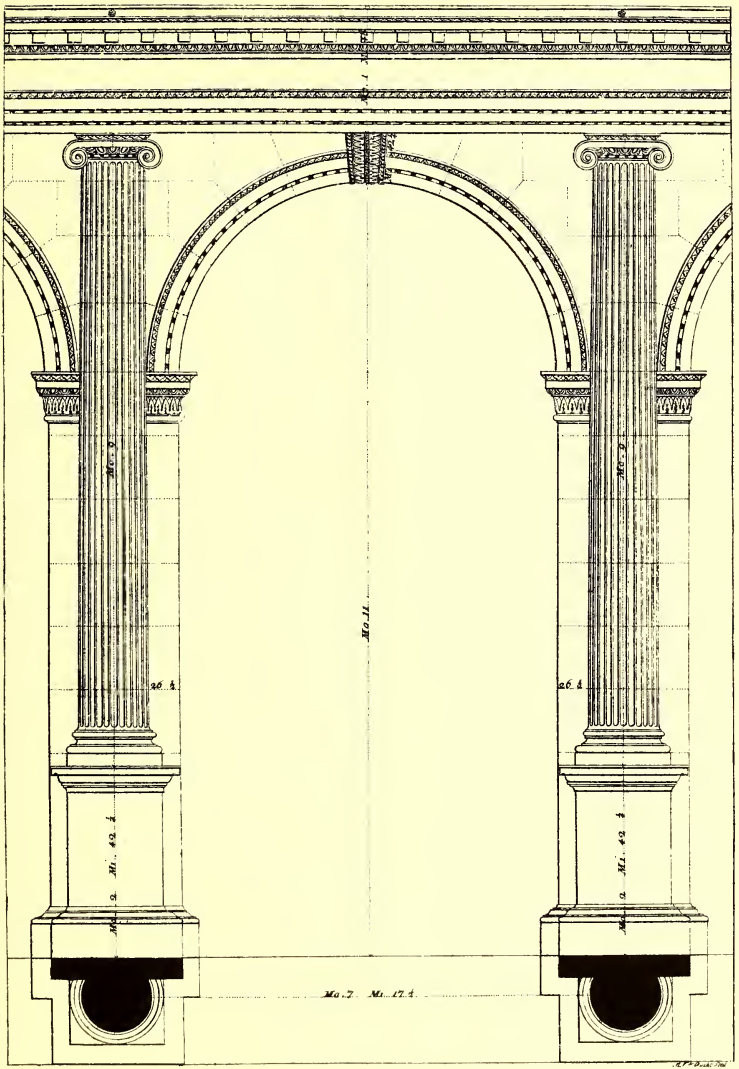

47. THE IONIC ORDEK.

ARCADE WITH haLF COLUMN ON PEDESTALS. 

to be published, for death intervened. It may have been written and lost, however. There is no doubt of Palladio's great qualifications for writing upon the subject, for his knowledge was unquestionable. In military art he would have competed with San Michele, who invented much of great benefit, the finest example of his ingenious fortifications being erected at Verona in 1527 .

Book II. contains the executed designs of several town and country houses, and also designs for certain noblemen in Venice, Verona, Vicenza and elsewhere. This book is divided into seventeen chapters, dealing (inter alia) with the proportion to be observed in private buildings, the planning of different rooms, the construction of town houses, the different forms of atrium, the private houses of the Greeks, the situation of country houses, and several designs for such buildings, including the celebrated "Rotonda" at Vicenza.

The notes of Inigo Jones on the margin and at the end of this book are of great interest. The different parts of the plan are lettered and referred to in this manner by Inigo Jones, who must have made these notes on the spot; thus adding great value to the book.

Book III. is devoted to the practical discussion of ways, streets, roads, bridges, the piazzi of the Greeks and Romans, ancient basilicas and their typical forms, and includes drawings of Palladio's great work, the Basilica at Vicenza. Notes, plans and restorations of the baths and xysti of the Greeks are also given.

Book $I V$. is in size equal to the first three books put together. It consists of descriptions of the temples of classic Rome, Italy, and some outside Italy. There are in all thirty-one chapters which treat of the various forms of temples, and their compartments. Measured drawings and 
restorations are given of such buildings as the Temples of Peace, Mars the Avenger, Antoninus and Faustina, Venus and Rome, Minerva, Medica, Jupiter, Fortuna Virilis, Vesta (Rome and Tivoli), the Pantheon, Castor and Pollux, all of which are at Rome.

Outside Rome the two temples at Nismes, those at Pola (Istria), are dealt with.

Inigo Jones's remarks are given in side-notes to many of these important temples, and in these he mentions the condition of the various buildings at the time of his visit. The interested reader should refer to the book for these, as it is impossible, in the space at our disposal, to do more than mention that the notes exist. In Leoni's edition there are one hundred and four folio plates, many of them of extreme interest, as showing the condition of the buildings in the sixteenth century, or as indicating in their restoration by Palladio what he considered their original appearance to be. In Leoni's edition the plates are carefully drawn and figured.

Book IV. has an Appendix on the "Antiquities of Rome," to which is added "A Discourse on the Fires of the Ancients," by Palladio. In this appendix is a reference to the foundation of the city, her principal streets, bridges, hills, the aqueducts leading into Rome, the theatres, amphitheatres, market-places, triumphal arches, porticoes, obelisks, palaces, courts of justice, granaries, etc.

In addition a good deal of interesting information is given about the everyday life and customs of the Romans, the population, weddings, education, divorce, funeral and other rites.

The discourse on the fires of the ancients refers to the different kinds of hearths and stoves, and the use of pipes for introduction of heated air. 


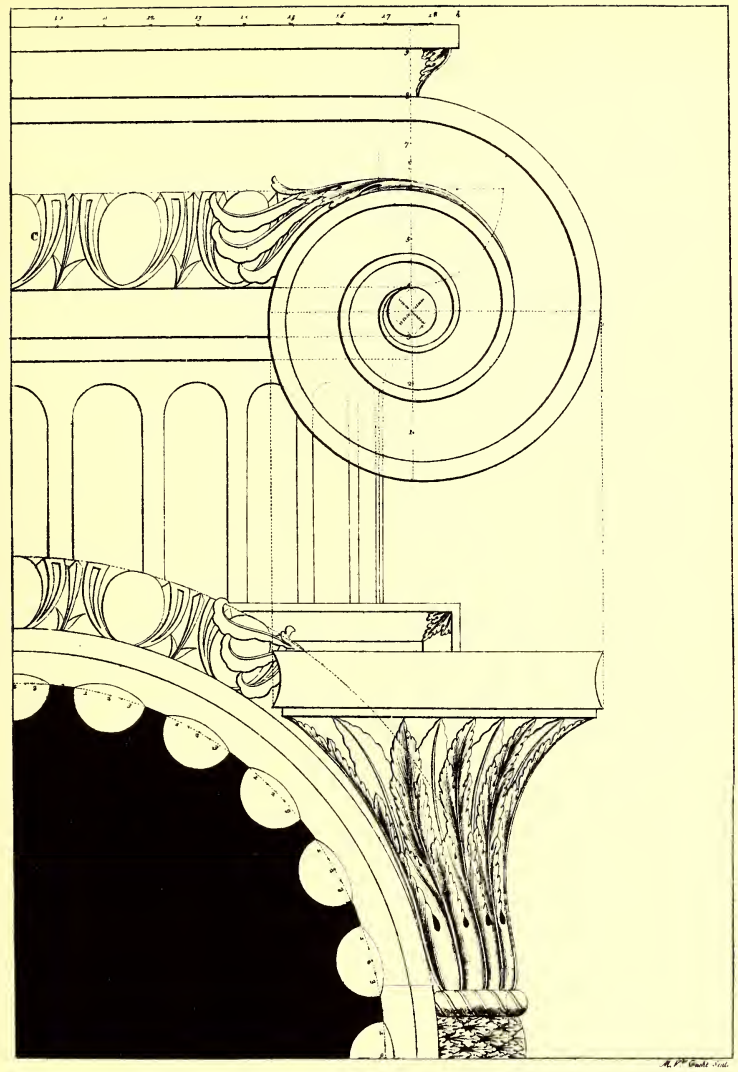

48. THE IONIC ORDER.

DETAlLS OF CAPITAL, SHOWING SETTING-OUT OF VOLUTE, ETC. 



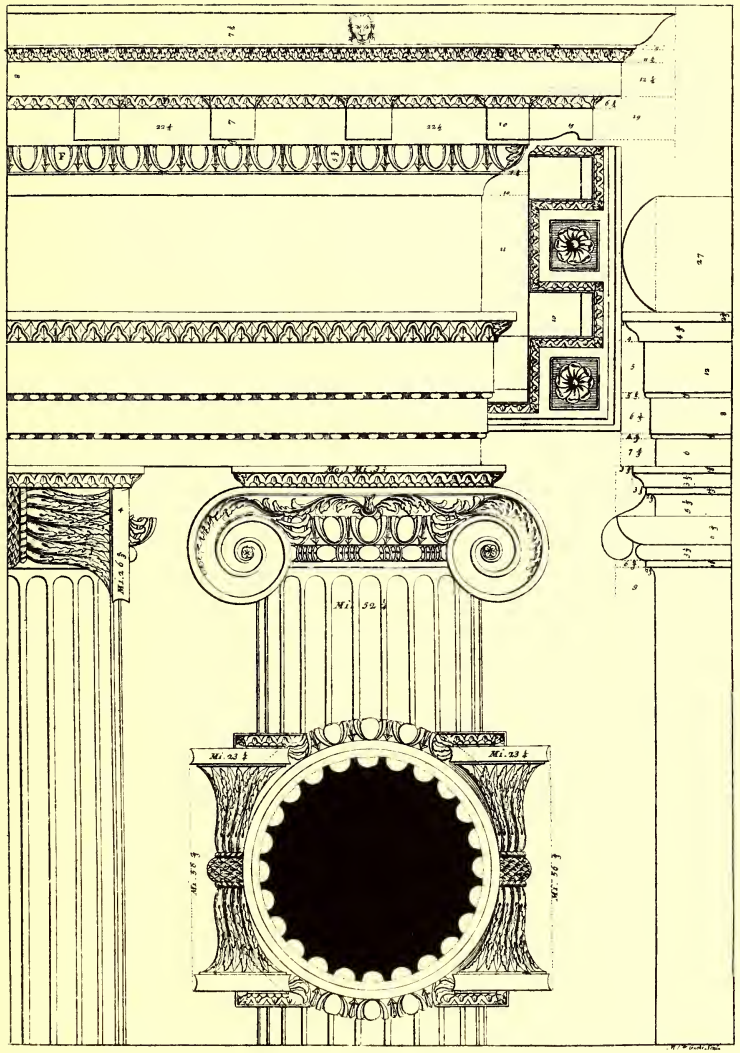

49. THE IONIC ORDER.

DETAIL OF ENTABLATURE AND UPPER P.IRT OF COLUMN. 

The various editions of Palladio's "Treatise on Architecture" are, as far as possible, given below.

Gualdo informs us that certain treatises on architecture promised to Emanuele Filiberto of Savoia remained unfinished owing to our master's death. It was known that he had, in the company of Monsignore Daniele Barbaro, visited the ruins of the Berga Theatre, outside Vicenza, and, anxious to discover records of any of these visits, Barichella, who had been a devout disciple of Miglioranza, wrote to Professor Donaldson, who kindly charged himself with procuring the Duke of Devonshire's permission to peruse the drawings by Palladio then in the Duke's villa at Chiswick, which was occupied at that time by the Prince of Wales (now King Edward VII.). In these inquiries Lady Mary Egerton gave her assistance, and the quest proved a successful one. Professor Donaldson found the drawing of the theatre, though not signed by Palladio, and forthwith made a beautiful sketch of it. Both Barichella and Donaldson believed entirely in the authenticity of this drawing, which contained almost accurately the form of the edifice. Miglioranza devoted many years of his life to the study of this particular theatre, and after his death Barichella continued the researches. It is believed that there was another building attached, which was used for the entertainment of august personages on their way through Vicenza. Theodoric is believed to have stayed here in 488 , Charles the Great in 802, Henry II. in 1039, and Lothario in I 128. 
THE VARIOUS EDITIONS AND TRANSLATIONS OF PALLADIO'S WORKS

Le Antichità di Roma. 8vo. Venice, I554, I555, I565 ; Rome, 1576.

Do. In Latin, I6I8.

Do. Another edition, with notes by Fairfax, I709.

Do. In French, by P. de Launay. 8vo. Arras, i6i2.

Do. In Spanish, by H. Francini. 8vo. Rome, I589.

The drawings for the edition of Vitruvius, published by Barbaro in 1556 .

I due primi dell' Antichita (now very rare). Venice, I570.

I Commentari di C. G. Cesare con le figure in rame fatte da A. Palladio. Venezia, Franceschi, I 575.

I Commentari di C. G. Cesare con le figure in rame degli allogiamenti de' fatti d'arme, etc. 4to. Rome, i6 8.

Fabbriche Antiche disegnate da Andrea PalladioVicentino e date in luce da Riccardo Conte di Burlington. Folio. London, I730.

Fabbriche Antiche, etc., published by Lord Burlington. London, 1730.

Do. Published by Cameron, I772.

(Works upon Polybius and on Theatres are not published.) Quattro libri dell' Architettura. Folio. Venice, I570. (With woodcuts.) Other editions in 1581, 1601, 1616, 1642.

The Architecture of Andrea Palladio, by Leoni. Folio. London, I7 I5, I721, I742 (third edition). (Containing notes by Inigo Jones).

The above printed in French by $\mathrm{Du}$ Bois in 1726 , with an Appendix on the Antiquities of Rome.

The Five Orders of Architecture, revised by C. Campbell. London, I729. 


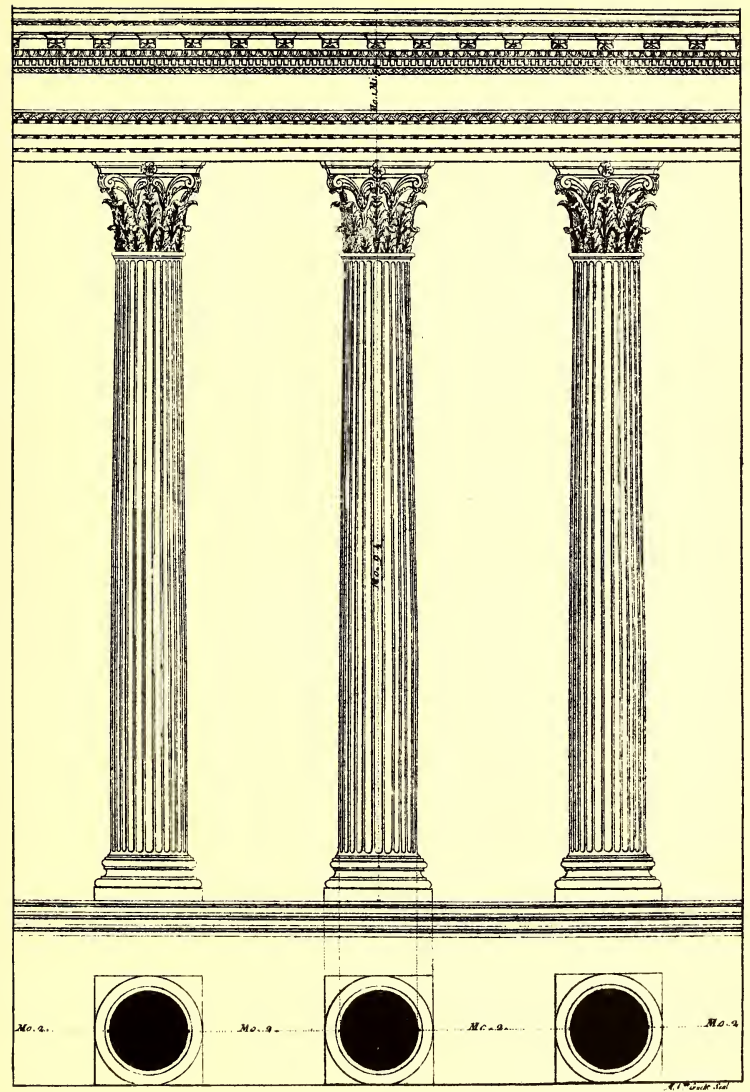

5O. THE CORINTHIAN ORDER.

GENERAI. PROPORTIONS OF A COLONNADE. 



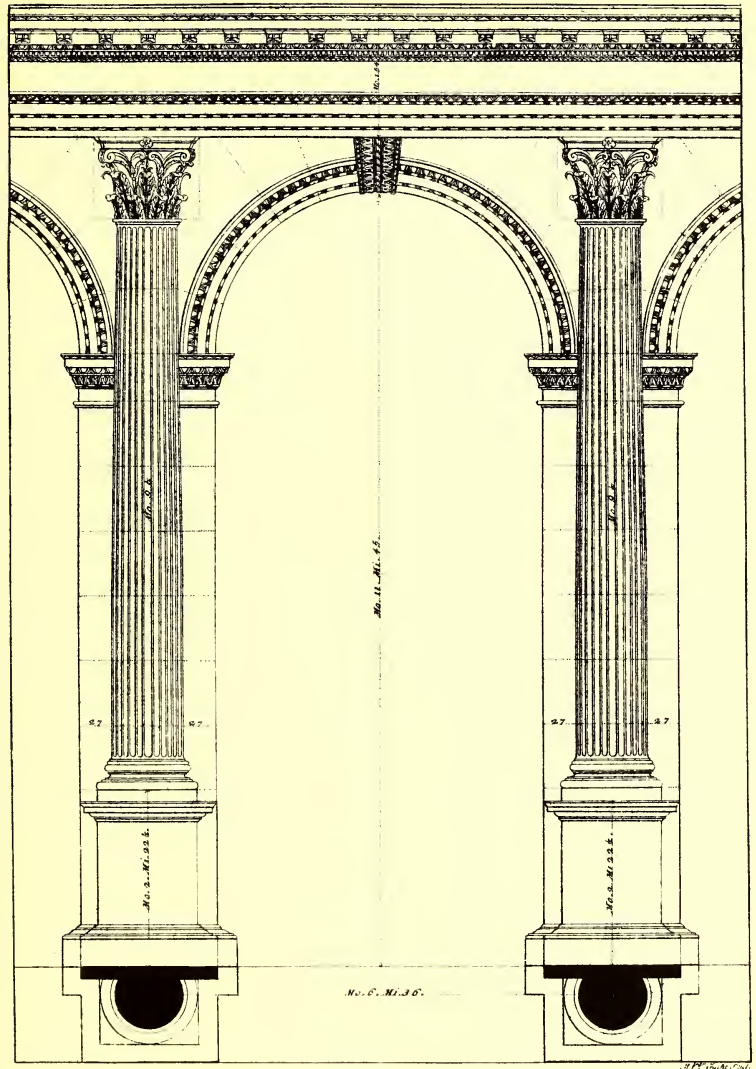

5I. THE CORINTHIAN ORDEK.

AKCADE WITH HALF COLUMNS ON PEDESTALS. 

Architecture de A. Palladio, by G. Leoni. 2 vols. folio. The Hague, I726.

The Architecture of Andrea Palladio, translated by I. Ware. London, I738 (now rare).

Also editions by B. Cole, with drawings by Hoppus. Folio. London, I735, I736.

The First Book of Architecture, translated by G. Richards. Early editions, and 4to (ninth edition). London, I72I and 1733 .

Traité des Cinq Ordres d'Architecture, par Le Muet. 4to. Paris, 1626, 1647.

Terme dei Romani. Scamozzi. Folio. Vicenza, 1785, 1797. (The baths of Agrippa are wanting in the above collection.)

Baths of the Romans, by C. Cameron. Folio. London, I775.

L'Architectura. French and Italian. Venice, I74I. Reprinted by G. B. Pasquale, I768, I770; Siena, I790; Paris, 1642 (second edition); by Dubois, 1726 (Hague).

Les quatres livres d'Architecture, par de Chamray. Folio. Paris, 1650 (first French edition).

Delle Cinque Ordini d'Arch. 1746.

Libro de la Arquitectura de Andrea Palladio, by F. de Praves. Circa 1625 (? Madrid).

Los quatros libros de Arquitectura. Civil traduc. par Ortiz y Sanz. 96 pl. Madrid, I797.

Les Batimens et les Desseins de André Palladio, recueillis et illustrés par Octave Bertotti Scamozzi. 4 vols. with plates. Vicence, I796.

(This edition has been utilized for measurements and information in this biography).

Le Fabbriche ed i Disegni, par O. B. Scamozzi. 1776, I783, I786, I787; a smaller edition in I796-1797. 
Architettura di Andrea Palladio, by N. N. 4to. Venice, I7II. And in eight volumes, folio. Venice, I740-I 748.

Architettura di Andrea Palladio Vicentino. Folio. I740, Venice. Italian and French text, "Con le osservazioni dell' Architetto," N. N.

Fabbriche e i Disegni di Andrea Palladio, e le Terme, by Foppiani (Genoa), I843-1844.

Cuvres complètes de Andrea Palladio, et la traité des Thermes, by Chapuy, Coricard, Lenver and Beugnot. Paris, I825, I842, I852.

N. N., Le Studio dell' Archit. di Palladio. 93 plates. Folio. Vicenza, I8oo.

The Edifices of Palladio, with measurements, taken with Atkinson, of the Olympic Theatre, Palazzo Chiericati, the screens to the "Sala della Ragione," and the Villa Capra, and Memoir of Palladio. F. Arundale. Folio. London, I832.

\section{PALLADIO'S DRAWINGS}

THE BURLINGTON-DEVONSHIRE COLLECTION OF DRAWINGS

IN THE R.I.B.A. LIBRARY. ${ }^{1}$

This important collection of drawings, of which about two hundred and fifty are believed to be by Palladio himself,

1 The first Earl of Burlington was one Richard Boyle, second Earl of Cork, who was made a peer of England in I644, as Baron Clifford of Lanesborough, co. York, and who in 1664 was created Earl of Burlington. Dying in 1697 he was succeeded by his grandson, who, in 1703 , was succeeded by his only son, Richard Boyle, fourth Earl of Cork and third (and last) Earl of Burlington, who was born in 1695 and died in 1753. The only surviving daughter of this, the celebrated Earl, married the fourth Duke of Devonshire; and thus the villa at Chiswick, its contents and heirlooms, passed to the Cavendish family. The third son of this marriage, George Augustus Henry, was invested with the revived title of Earl of Burlington, and he was succeeded by his grandson William (second Earl of Burlington of the revival) and seventh 


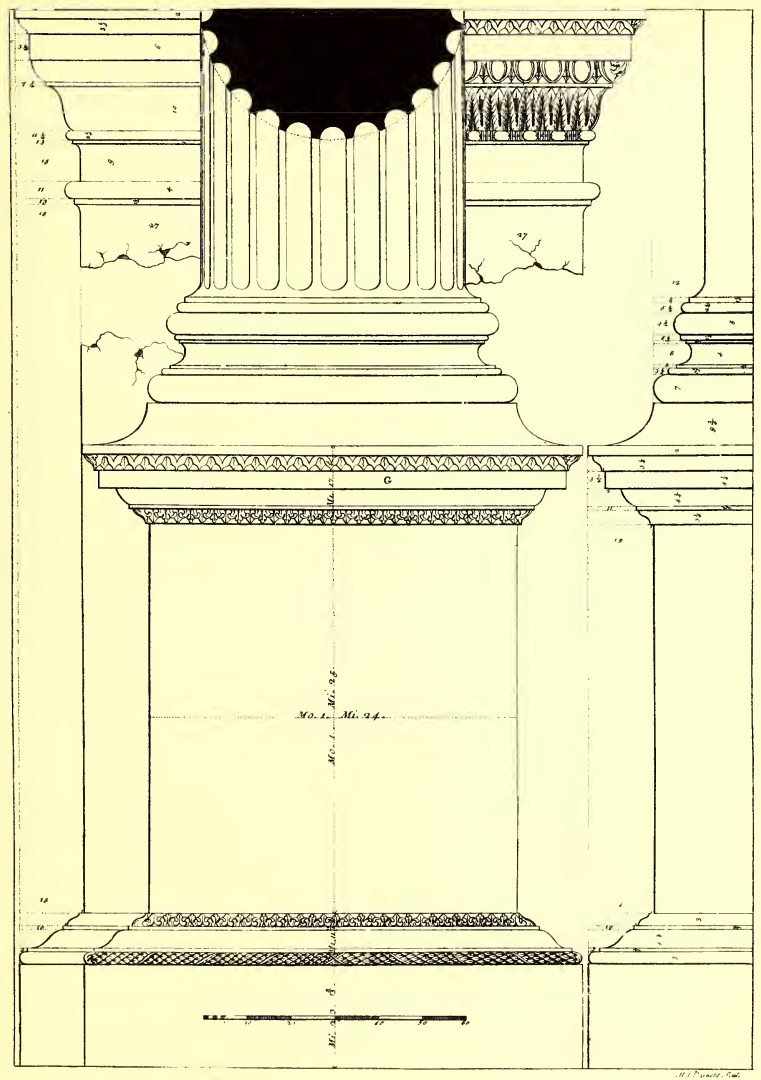

52. THE COKINTHIAN ORDER.

DETAILS OF BASE OF COLUMN AND PEDESTAL AND IMPOST OF IRCADE. 



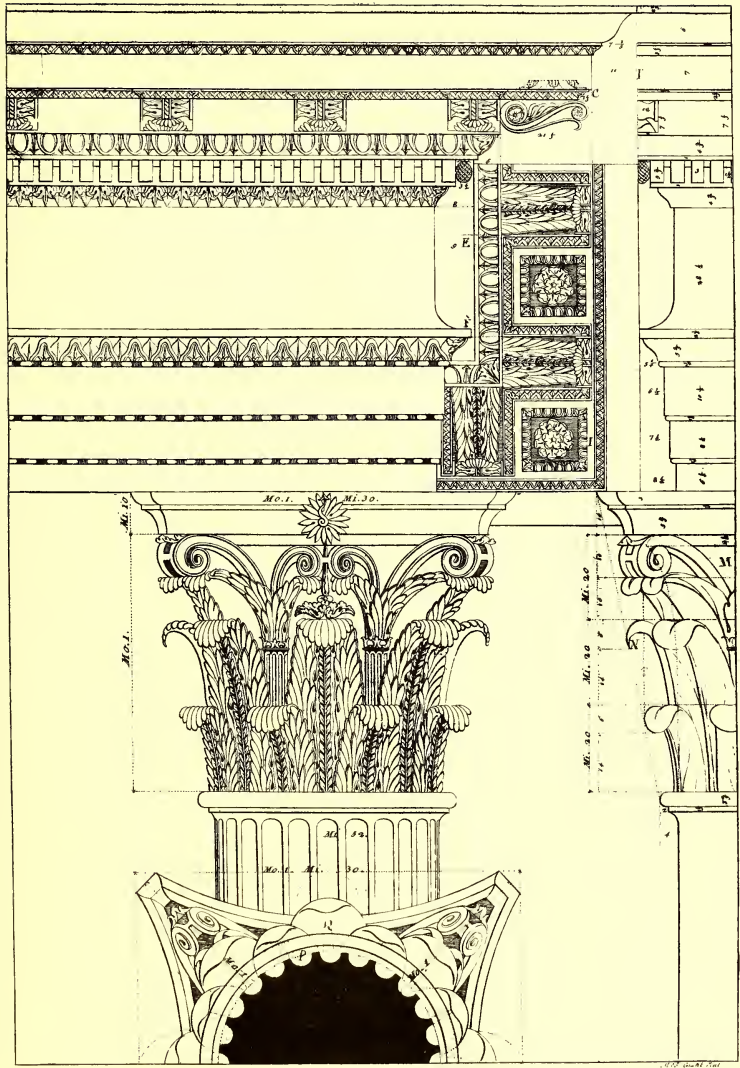

53. THE CORINTHIAN ORDER.

1)ETAII. OF ENTABLATURE AND UPI'ER PART OF COLUMN. 

is now in the Library of the Royal Institute of British Architects. The first notice in recent years of this collection was at a general meeting of the Royal Institute held on the I 7 th November, I845, by Mr. Ambrose Poynter and Professor Donaldson. The paper was called "A Note on the Collection of Architectural Drawings by Andrea Palladio, in the possession of the Duke of Devonshire at his villa at Chiswick, near London."

Messrs. Poynter and Donaldson described the drawings as contained in portfolios and books of folio size, bound in russia or morocco leather, and they proceeded as follows : Those in the portfolios are all mounted, apparently on foreign boards, and many of the sheets, having sketches on both sides, are attached to the boards at one end only, so as to leave the back free for inspection. Many of the drawings have the lines in bistre, and some are shadowed with finely drawn lines; others with a wash tint. They are of two classes, either sketches from original monuments or designs, having dimensions and memoranda upon them, or drawings fairly made out, many of which are probably by another hand, as several are purely elementary drawings of the orders, or plans of temples, sepulchres and other edifices, most likely prepared for publication. The memoranda are written in a cramped Italian character of the period, with frequent abbreviations and peculiar orthography. There is not a signature of Palladio on any one of the drawings; some have the name of the edifice to which they relate, others have no indication of the object they are meant to illustrate. As already stated, about two hundred and fifty of these drawings are believed to be by Palladio himself,

Duke of Devonshire, who died in 1892, and was succeeded by his son, the present Duke, who, as Lord Hartington, formerly sat in the House of Commons as Member for Rossendale. (R.I.B.A. Transactions, 1892.) 
and if this is the case it will be understood how important and valuable is the collection.

The drawings are in seventeen portfolios, in seven of which are figured the Baths of Constantine, Vespasian, Nero, Titus, Diocletian, Antoninus (Caracalla), and Agrippa (all in Rome). With the Baths of Agrippa in Portfolio VII. was a bird's-eye view of Rome, dated ${ }_{1562}$, showing the city before the completion of the Renaissance Church of St. Peter.

In 1892 when arrangements were being made to remove the collection to Chatsworth, these drawings were lent by the Duke of Devonshire for exhibition at the Institute, and a more careful examination was made of them by Messrs. Wyatt Papworth and J. D. Crace, at the same time comparing them with the original description taken in 1845 .

Titles of the seventeen volumes of Palladian drawings and designs in the Library of the Royal Institute of British Architects:

I. Therme di Constantino in Roma.

2. Therme di Vespasiano in Roma.

3. Therme di Nerone in Roma.

4. Therme di Tito in Roma.

5. Therme di Dioclesiano in Roma.

6. Therme di Antonino in Roma.

7. Therme di Agrippa in Roma.

8. Fabrichi Antichi.

9. Edificii Antichi.

Io. Do.

I I. Do.

I2. Do.

I3. Disegni di Andrea Palladio. Della Carita, Teatro Olimpico. The Orders. Pedestals, etc. 


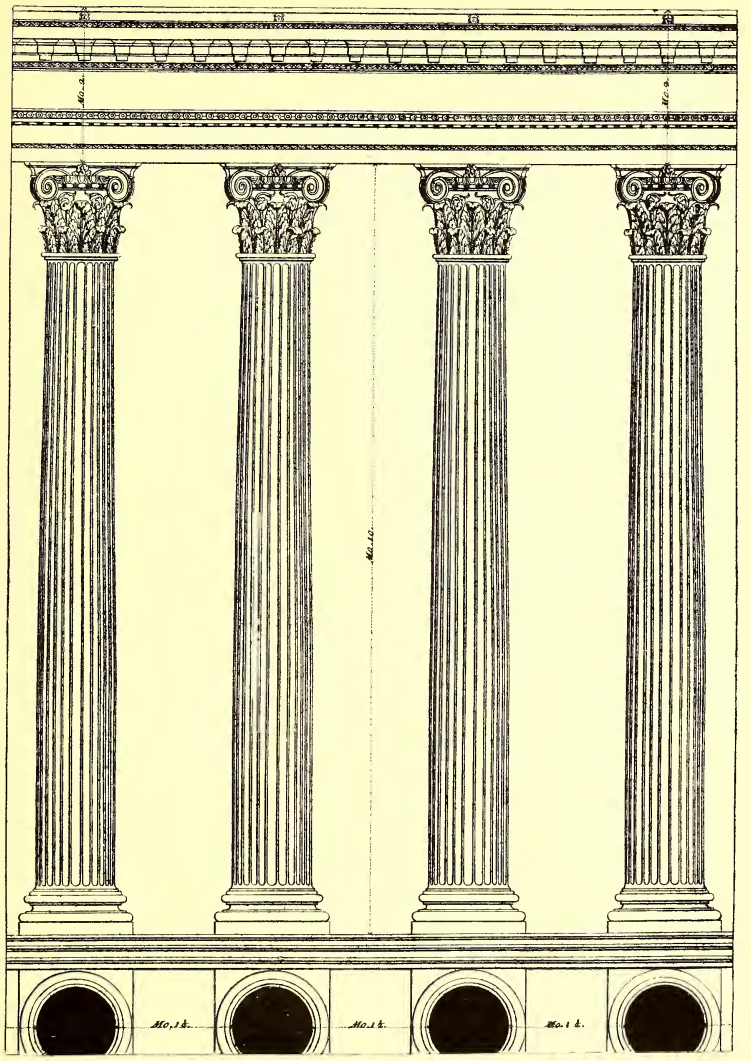

54. THE COMPOSITE OKDEK.

GENERAL PROPORTIONS OF A COLONNADE. 



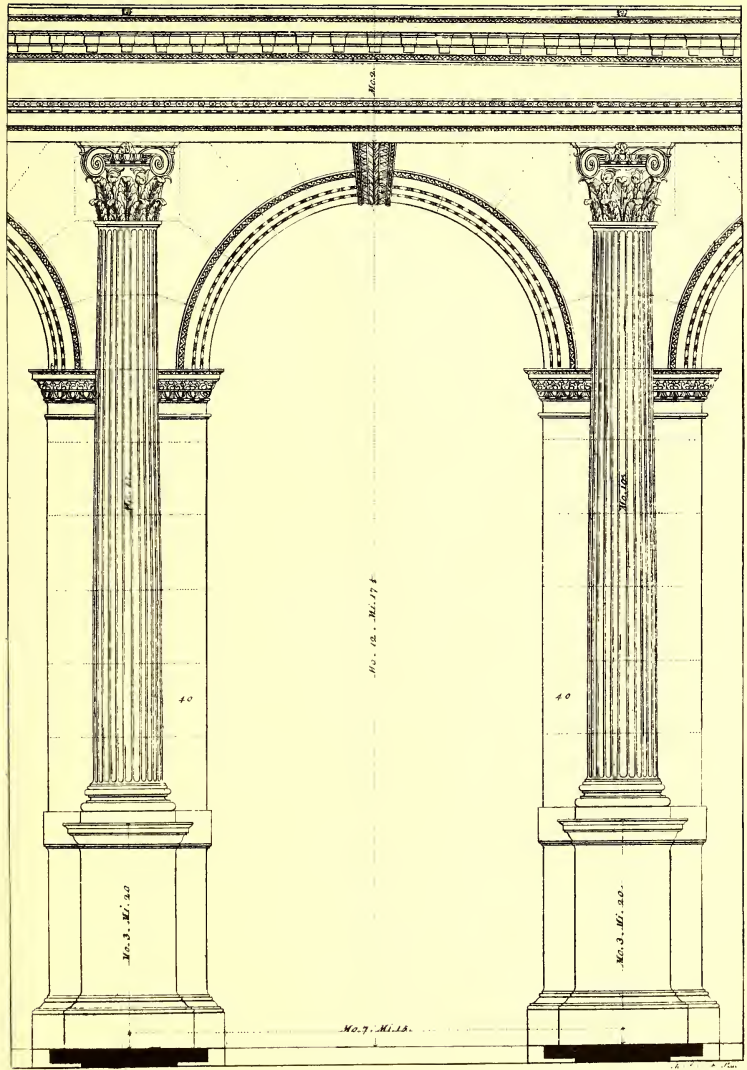

55. THE COMPOSITE ORDER.

ARCADE WITH HALF COLUMNS ON PEDESTALS 

14. Disegni di Andrea Palladio. Churches, etc.

15. Edificii Antichi di Andrea Palladio. Temple of Peace, etc.

16. Disegni di Andrea Palladio. Country houses.

17. Disegni di Andrea Palladio. Country and Town houses, including the Valmarana Palace, Chiericati Palace, and Thiene Palace.

The more important of the measured drawings of ancient buildings, besides those of the great Therme already mentioned, are plans, sections, elevations, and details of the following: amphitheatres at Verona and Pola; Colosseum at Rome; some ancient theatres; the Temple of Fortune at Praeneste; several temples in Rome and other parts of Italy; the Pantheon; the tomb of Theodoric at Ravenna; the Villa Adriana near Tivoli; a Septizonium; the Baptistery of Constantine; the arches of Septimius Severus, Constantine and Gallienus; gateways at Verona and elsewhere; and doorways at Spoleto and Spalato. There are also many drawings believed to be by Palladio of designs for houses and palaces of different kinds, many of these being executed, as for instance the Palazzi Chiericati and Thiene at Vicenza, the scene of the Teatro Olimpico at the same town, the courtyard of the Convento della Carità at Venice, and other buildings.

It would have been interesting if drawings of the Rotonda (Villa Capra) had been preserved, as it was copied so extensively in after years all over Europe, but no drawing exists of this building.

The whole collection forms a most valuable and interesting record of our architect's works and methods, and of the architectural draughtsmanship of the period.

In addition to the Burlington-Devonshire Collection must 
be mentioned a very interesting set of his designs and drawings of ancient edifices which are in the Museum at Vicenza. His drawings attracted the attention of dealers at his death, and some were in the possession of Contarini, Scamozzi, Albanesi and Vasari. The largest collection was bought by Giuseppe Pinali and Lord Burlington. Pinali bequeathed his to Vicenza and Verona, among those at Vicenza being the Arch of Tito and that of Septimius Severus, the temples of Trevi, of Marte and Tivoli. In I732 Lord Burlington published his collection in London. 


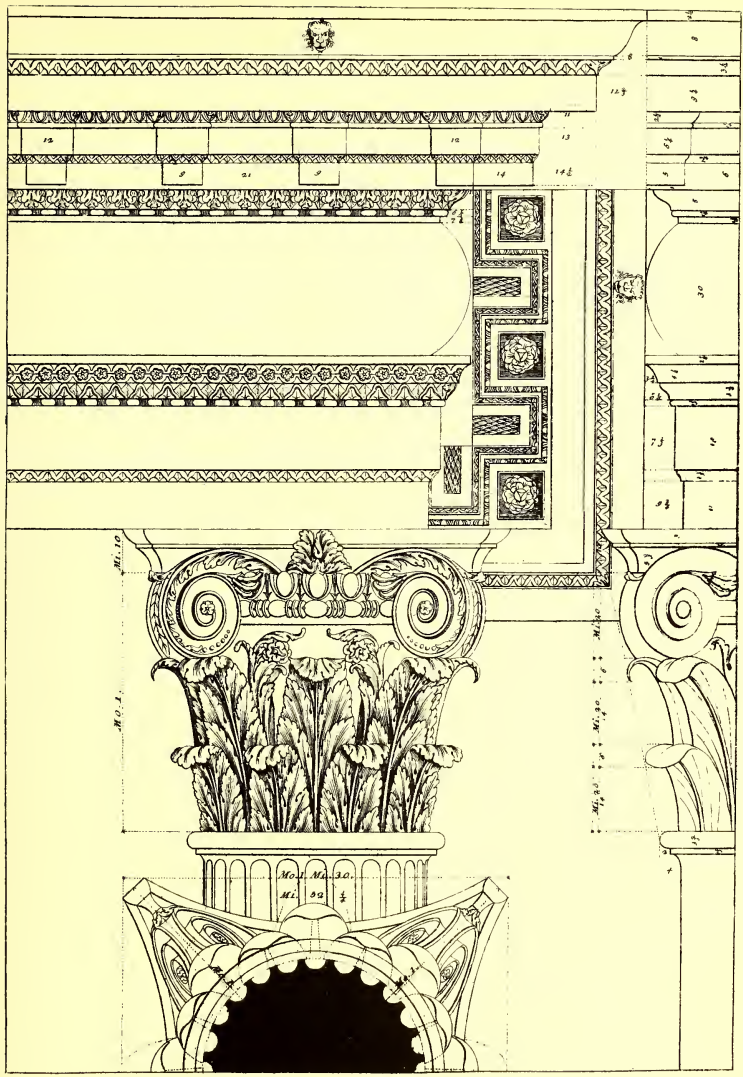

56. THE COMPOSITE ORDEK.

DETAIL OF ENTABLATURE AND UPPER PART OF COLUMN. 



\section{CHAPTER IX}

ANDREA PALLADIO'S FAMILY AND DECLINING DAYS

\E have no information regarding Palladio's marriage, neither do we find any mention made of the wife of so famous a man. She is merely called "Moglie," a word much used in these days even in the noblest families. Her death is also shrouded in uncertainty. It appears a tomb was built by Silla, Palladio's son, and Della Fede, his son-in-law, two years before his own death, and we can but surmise that this may have been for his wife, if not for her, then probably for his only daughter, Zenobia.

Palladio had a family of four sons and one daughter. The eldest son, Marc Antonio, became a sculptor, like his father; we find him living at Venice in ${ }^{5} 58$, and he died in 1600 . Leonidas, who assisted his father, died about 1574 . We read of his directing the building of the dome at Montagnana in $1566 .{ }^{1}$ Silla, the youngest, was an architect, and assisted by Scamozzi, completed the Teatro Olimpico, upon which his father was engaged at the time of his death, and died about I627. Zenobia married Giovanni Battista, afterwards Della Fede, a goldsmith, whose name appears inscribed in the guild of goldsmiths at Vicenza.

Orazio, the third son, studied law in Padova in 1564 . He was capable, it seems, of writing cultivated poetry, and a sonnet to Giovanna Aragona in I 568 shows great nobility of thought and elegance of style. He died about 1574 .

$$
1 \text { "Memorie Intorno." A. Palladio. }
$$


Palladio, who appears to have been a most devoted father, gave up much of his time to the instruction of his sons. His treatise upon the works of Caesar in 1575 contained copper engravings executed by them.

It is extremely pathetic to think of the great man's grief at the loss of his beloved children. His two sons died within a little more than two months of one another, and the father was inconsolable, and all interest in his books and profession remained dormant for some time. In writing of this trial to Cesari Palladio remarks, "Ma non ebbero grazia di condurre al desiderato fine cosi lodat pensiero perche interponendosi fra i loro disegni la morte, dell' humana contentezza e gloria incidiosa, con mio gravissimo acerbissimo dolore, nello spazio di due mesi e mezzo d'essi ambedue privo e sconsolato mi lascib."

Before the year 1564 Palladio was in legal documents called "of Vicenza" and "inhabitant of Vicenza." In those relating to the marriage of his daughter he appears as "civis Vicentine," a distinction worthy of mentioning in the days of the republic. None of the honours conferred upon Palladio can exceed the publication of his works and those of his school. This labour was undertaken with much courage and diligence by Ottavio Bertotti Scamozzi, who measured, drew and restored his buildings. This book contains most interesting engravings and commentaries, showing much learning and scholarship. It is a colossal work, embracing four large volumes, of which many editions have appeared both in Italian and French. ${ }^{1}$

The house, to be seen in the street of S. Lucia, Vicenza, was small and unpretentious, one of many such, and it is held by some that he lived here from 1560 till his death. ${ }^{2}$

1 See list, page I05.

2 Andrea Palladio e la sua Scuola. 
It was built, it is believed, by Cogolla, and was originally in the possession of this family.

Though infirm for a long time, Palladio nevertheless continued to take an active part in the building of his edifices, and when finally the end came, it found him at work upon one of his finest efforts, the Teatro Olimpico, finished after his death by his son Silla and Vincenzio Scamozzi.

Palladio's death was a great grief and loss to his loyal native city, which revered him not only for his genius but for his many other virtues-for he was both amiable and benevolent, and beloved by his workmen. The Academicians of the Olimpico attended his coffin to S. Corona, and placed it in the vault there which at first faced the altar of S. Giovanni, but when the church was repaired, the marble slab with the olive branch and the two hands joining was moved into the wall of the choir, above one of the staircases leading into the confessional.

By the will of Count Velo and with the funds left by him a sumptuous chapel was erected in commemoration of Palladio, in the Cemetero Comunale, and his remains were disinterred and carried in solemn procession from the Sepulchre at S. Corona on the 19th August, 1845, the anniversary of the great architect's death.

Canova honoured Palladio with a bust, placed at the cemetery, with the following inscription :

\author{
AD ANDrea Palladio \\ DI VICENZA.
}

Antonio Canova.

Professor Todeschini denies that the sepulchre could be Palladio's, as he considers the olive branch to be the badge of the Olivieri family, but Magrini and Gonzati bring 
evidence to prove that Silla, Palladio's son, on May 3rd, I578, received the permission to construct this tomb as a burial-place for his family and that of Della Fede, his brother-in-law, husband of Zenobia. Documents were also found later, showing that the olive branch was the insignia of Palladio's family, one in particular is a will, in which Silla seals his testimony with this symbol.

When the ceremony of removal took place in 1845 , the remains of Palladio were placed in an urn modelled after a design of his own, which formed part of the treatise on the baths of Agrippa. It is surmounted by two figures representing the artist and a genius crowning him. At the sides are two additional figures representing the art of Architecture and Vicenza. This monument was erected by Giuseppe Fabris. On the evening of this eventful day a noble catafalque, draped in black and illuminated by numerous wax tapers, was carried on to a funeral car designed by Professor Giovanni Bellis. It was composed of motifs introducing some of Palladio's own designs, and further adorned with floral wreaths. A cereal, symbol of immortality, surmounted by a cross of laurel surrounded the ashes, and long streamers floated in the evening breeze. The car was drawn by horses, while military banners and solemn music accompanied the long line of church dignitaries, of scientists, architects, and representatives of various societies. The cortege moved slowly through the decorated Corso Principe Umberto and the street of S. Lucia. And so, after three centuries, our master's ashes were carried over ground he so frequently had trodden during life. A loud volley of cannon proved an impressive finale to the solemnity of the occasion. Francesco Bressan in I86I erected a statue to his memory, by Vincenzo Gaiassi, in the Piazza de' Signori, at Vicenza. Here he is depicted in 


\title{
FAMILY AND DECLINING DAYS II5
}

pensive attitude, holding in one hand a compass with the sketch of a design. The left arm is bent, the hand supporting the chin. On the socket near the right foot is the fragment of an Ionic capital, upon which falls an acanthus crowned by a serpent, the symbol of immortality. A society of Vicenza also had a bust of our master executed with the following inscription :

\author{
Andrea Palladio \\ ARChitetTo Vicentino \\ Per Maesta Romana di EdificiI. \\ E SAPIENZA DI SCRITTI \\ SOMMO IN PATRI E FVORI. \\ La Societa di Mutuo Soccorso. \\ Degli Artigiani Vicentini. \\ M.D.CCCLXXI.
}




\section{CHAPTER $\mathrm{X}$}

THE INFLUENCE OF PALLADIO AND HIS SCHOOL

TO art can be brought to a successful issue without a 1 long and intimate knowledge of that which has been done before, and of the various motives which combined to produce those examples of approved form and design throughout successive ages. In Reynolds's opinion, "the greatest natural genius cannot subsist on its own stock, he who has laid up no materials can produce no combinations. The more extensive his acquaintance is with the works of those who have excelled, the more extensive will be his power of invention."

It was the possession of this knowledge of the art of the past, gathered by careful study of ancient buildings and of his great master, Vitruvius, together with a clear and natural intuition, a sense of harmony, just proportion, and an avoidance of dangerous precedent, which raised the art of Palladio to the foremost rank even among modern creations. The great influence of his book on architecture has been already mentioned. The school of Palladio is without doubt that which is most universally followed in all Europe, more especially in civil buildings. De Quincy considers "that the style of Palladio has a propriety which must have facilitated its propagation, a medium between a vigorous severity and licentious anarchy of those who refuse to recognize rules, which rules of course allow of 
exception." He adds, "the talent of Palladio is doubtless the principle whence this facility emanates."

Much of Palladio's care and attention was devoted to the interior convenience of his buildings, and this was seldom sacrificed to exterior considerations of effect. He also suited his art to the needs of his patrons, and when so desired seldom incurred unnecessary outlay, though successful in accomplishing a satisfactory agreement between the necessary and the ornamental. Much beauty is to be found in the façades and quadrangles of his palaces. There are many of these in Vicenza-some built merely on the side of narrow streets, from which it is almost impossible to view them with any degree of satisfaction. The most important are the Valmarana, Barbarano, and the Porto Palaces. It is not to be expected that our architect has succeeded in escaping the censure of critics; but where is absolute perfection to be found, and if found, acknowledged? In some opinions the work of Palladio is only excelled by the magic work of the ancients, and it must be held that modern Palladianism occupies the first place in the list of modern styles. This Palladian manner includes the results of the efforts of others in the revival of Classicalism, viz., Vignola, Scamozzi and Serlio-Palladio's contemporaries. It expressed a revolt against the extreme licence both of composition and ornamentation into which the architecture of his time had fallen. We have had occasion to remark already that Palladio's art does not meet with universal laudation. To some "it is dull and lifeless, dominated by scholasticism, and regardless of considerations of utility and convenience;" but these charges cannot in the majority of cases be held as proved against our master himself, but rather against his unsuccessful imitators. Many of Palladio's works were monumental in which the qualities 
of impressiveness and grandeur may outweigh to some extent the mundane considerations of less important buildings in which the element of use and fitness predominate over other considerations. In important public buildings the aesthetic quality should prevail. There is no doubt, however, that he was fascinated by the splendid proportions of the buildings of ancient Rome, and that on occasions some of his designs were too imposing for their purpose. Reproductions of the great and stately edifices of Rome were not entirely in accord with the needs of the sixteenth century, and especially was this so in climates other than that of Italy. An example of this is to be found in the villa at Chiswick, erected by Lord Burlington and now the property of the Duke of Devonshire. Some critics condemn Palladio's Corinthian capital as having a clumsy profile, and also the panel of bas-relief which he so frequently introduced over the lower windows. Undoubtedly he possessed a power of producing great simplicity united to grandeur, which can be most clearly appreciated in the façade of the Thiene Palace. Donaldson believes Vignola and Serlio to have influenced much of Palladio's taste. The following are a few of the points to be observed in regard to his style. Pedestals, either with panels or raisings, were generally avoided by him. Architraves were very rarely sculptured, and the upper ornaments of his entablatures were carefully centred above each other. The doors, windows and niches were composed with the greatest simplicity, and when pediments were used, they invariably appear unbroken. The members of his cornices were in just harmony with the character of the order employed, and his arrangement of profiles carefully adjusted. In many of his edifices he undoubtedly shows a leaning towards the Ionic order, though he often employed the others. 
Probably in no particular has the Palladian influence been so marked on English buildings as the excessive height which he gave to his apartments. In his Book I. Chapter XXIII., in dealing with this, he observes, that in rooms with a flat ceiling the height of the apartment should be equal to its breadth.

It was the endeavour of the seventeenth and eighteenthcentury architects to follow these proportions, which, although of value in a hot climate, like Italy, were totally unsuited to that of England.

In vaulted, square apartments Palladio held that the height should be a third more than the breadth, but in those whose length exceeds their breadth, a height proportional to the length and breadth together may be easily found "by joining both the lines of the length and breadth into one line, which being divided in the middle will give exactly the height of the arch." These proportions were adopted largely by English writers and architects, and Gibbs in his book on architecture practically adopts them. Thus hard-and-fast rules were applied to cases which should be designed for the special use to which apartments were to be put, resulting in the lowering of architectural design to mere rules, without regard to the essential quality of fitness and propriety.

On the continent of Europe, Palladio is held by certain writers to have exercised a certain influence, and according to Quatremère de Quincy became the most universally followed master in all Europe, and in some sort the chief of the modern school in civil buildings.

In Germany it seems certain that little influence was felt, for that country was too much indebted to other Italian masters and even to France to produce any specimen of the school. 
As to France, says Boffrand, Milizia, in "l'Hôpital des enfants trouvés," and Goudouin, in "l'Ecole de Médicine," were followers of Palladio, but their works, although differing from contemporary architecture, are not striking specimens of his school.

In regard to England, it must be borne in mind that during the Elizabethan and Jacobean periods the orders of architecture had been used without any special reference to recognized proportions or rules, but according to the will and fancy of the designers, and although many delightful and pleasing combinations were effected, there is a want of stateliness and harmony about their application, which was altered by the introduction of Palladian measurements by Inigo Jones, the great English architect. Henceforward the orders of Palladio became the stock-in-trade of every trained architect, carpenter and mason.

Inigo Jones (1572-1652) was the pioneer of Palladian architecture in England, and it must be confessed that no student so thoroughly studied his master's works as did Inigo Jones those of Palladio. He, however, had his transition period, in which the expiring Elizabethan and Jacobean style contributed the detail, as seen in the beautiful garden façade of St. John's College, Oxford, and in the north and south sides of the quadrangle in the same college. His journeys in Italy, and the notes on his own copy of Palladio's book, show that he went about his task in no half-hearted way, but carefully examined each building and made his notes and remarks thereon. Inigo Jones became, in short, saturated with Palladianism, whose work he naturalized in England, and through him Palladio became the great master of the English fully developed Classic Renaissance, or as it is sometimes called the Anglo-Classic style. The change introduced in architectural style by 
Inigo Jones's use of the Classical orders of architecture was extraordinary in its results and far reaching in its effect. As mentioned, he preferred Palladio's proportions of the orders, and studied them very thoroughly in our master's buildings at Vicenza and elsewhere. Inigo Jones was invited to Copenhagen by the King of Denmark, but he returned to England in the train of the wife of James I. But afterwards, when he must have been in a lucrative practice, he left everything for another visit to Italy in $\mathrm{I} 6 \mathrm{I} 2$. Palladio's influence on English architecture was therefore, through Inigo Jones, paramount, and it must be a matter for regret that, but for the intervention of the Commonwealth, Jones's most important design, the great palace at Whitehall, was never completed.

The Banqueting House (afterwards the Chapel Royal and now the Museum of the United Service Institution) in Whitehall was the only part of this magnificent scheme which was carried out. This masterpiece shows the skill with which Inigo Jones, although working on the lines of his Italian master, gave to his designs that English character for which they are distinguished. This building was erected in I6I9-162I, and, as already mentioned, forms a small part only of one of the grandest architectural conceptions of the Renaissance.

In the façade the space under the upper architrave is decorated by festoons, a feature specially suitable for a festive building.

The greater part of the building, which is illustrated in Inigo Jones's designs by W. Kent, was to be three storeys in height; each storey 30 feet, and the height to the top of the parapet was to be Ioo feet. The remainder being curtain wings to the main blocks, in design like the Banqueting House, was to be 75 feet high divided into two storeys. 
The plan of this structure was a masterpiece; the buildings were to be arranged round courtyards, one of which was to be circular, and known as the Persian Court.

As showing the continuity of English tradition, although the chain is occasionally broken, the late Mr. J. M. Brydon schemed a circular court in connection with the new government offices which are being erected from his designs in Whitehall. The great court of Jones's magnificent palace would have vied with that of the Louvre. In the executed portion-the Banqueting House-he has in many respects outvied his master. The extraordinary amount of variety which he has obtained in what is apparently a stolid Classic front is remarkable. It will be observed that no two adjacent columns are alike except the two central ones, the others, either by coupling, or making them three-quarter or half columns, are all different on each side of the central axis of the building.

There is a sobriety and dignity about the whole building which well expresses Palladio's methods of design.

It was in the arrangement and design of the "Court Masques" of the Stuarts that the genius of Inigo Jones first found a field for the display of his Palladian principles. In the interior decoration of his best works Inigo Jones showed his extraordinary knowledge of architectural detail. Palladio's buildings were mostly shells in which the ornament was lavished on the exterior. Jones, however, carried the details of the style throughout the interior fittings, and excelled in such features as doors, windows and chimneypieces. His deeply coffered ceilings in compartments it is said were introduced from France, but they accord perfectly with the bold style of his architecture.

Among others of Inigo Jones's works which show Palladian influence may be mentioned the river façade of Green- 
wich Hospital, executed by Webb, one of his pupils. In this building the two lower storeys are included under one huge Corinthian order. York Water Gate, London, St. Paul's Covent Garden, houses in Lincoln's Inn Fields, Chevening House, portions of Wilton House, including the Palladian bridge, and Stoke Park, may be mentioned as other typical examples.

This latter building, erected in 1630-1634, shows very direct Palladian influence, especially in the plan. The central block, or corps de logis, has semicircular wings as colonnades, with a library and chapel at either end. This type of plan is one of many erected or designed by Palladio in the neighbourhood of Vicenza, several of which must have been seen by Jones during his visit to Italy, and of which there are illustrations in Palladio's book. See Plate 3 I.

The enthusiasm of Lord Burlington (I695-1753) for Inigo Jones is well known, and it is recorded how a design for a gateway by the latter was given to Lord Burlington by Sir Hans Sloane, who had it removed from Beaufort House, Chelsea, to Chiswick House, where it may still be seen.

Pope has the following lines on this gateway:

"O Gate, how cam'st thou here?

I was brought from Chelsea last year

Batter'd with wind and weather.

Inigo Jones put me together;

Sir Hans Sloane

Let me alone :

Burlington brought me hither."

Lord Burlington also published Inigo Jones's designs for Whitehall with his own and those of Kent ; this is interesting as showing the high estimation he held for the genius of these two architects. 
Thus the influence of Lord Burlington on the later English Renaissance must have been very great. He was a passionate admirer of Inigo Jones and of the latter's great master, Palladio. During his visits to Italy, and his life there among the works of Palladio and the artists of the day, he seems to have acquired an extraordinary liking and interest in the works of Palladio and his school. His collection of drawings by Palladio, already mentioned, and of works by other artists of the period, must have helped very much to familiarize their peculiarities to his entourage, and to have popularized the art of Palladio, which has had such an extraordinary influence on English architecture.

So much is this the case, that the term Palladian has for long been an accepted word, meaning much more than the art of Palladio, and one used much even by novelists to express the certain dignified character of eighteenth-century English architecture.

Giacomo Leoni was brought over to England by Lord Burlington in 1715 , especially it would appear to help in the translation of Palladio published in that year. Remaining in England he executed a number of important buildings, such as Latham Hall, Moor Park, etc., which must have influenced contemporary architecture.

Leoni also published in 1726 an edition of the architecture of Alberti, the great Florentine architect. He died in 1746.

The fully developed English Renaissance architecture was therefore given its first great impulse at the commencement of the seventeenth century by Inigo Jones, who founded his style on that of his great master, Palladio, whose works he had studied so thoroughly in Vicenza and elsewhere. Thus, although founding his designs largely on Italian or rather Palladian precedent, he gave to them a 
peculiarly English character, attempting to make them, in his own words, "solid, proportional, according to rules, masculine and unaffected." This tradition was continued with interruptions to the close of the eighteenth century by a body of English architects who were in a general way influenced thereby.

To trace this progress step by step would take us beyond the space at our disposal, but a glance at a few of the principal architects and their works will help us to understand the development.

John Webb (pupil and nephew of Jones) was responsible for Amesbury House, Wiltshire, in the Palladian manner, and Dr. Henry Aldrich erected the Peckwater Quadrangle of Christ Church, and the church and campanile of All Saints, Oxford.

Sir Christopher Wren was born twenty years before the death of Inigo Jones in 1652 . Although his early education was that of a man of science rather than an architect, he had extraordinary opportunities opened up to him by the great fire of London in 1666. His study of the Louvre and other buildings at Paris gives a French tinge to some of his work, but it is, in general, essentially Palladian in character as compared with the methods of Vignola who was the leader of the French school.

The extraordinary amount of work executed by Sir Christopher Wren, and the influence of Palladio and Inigo Jones on his designs had the direct result of leaving a number of buildings which would act as models for succeeding generations of architects.

Besides St. Paul's, London (Jones had added a Classical portico to the old Gothic church which it replaced), which bears the impress of Palladio in the sturdiness of its conception, Wren was responsible for the building of some fifty- 
three churches in the city of London, erected between the years I670-I7II. In most of these there is discernible the influence of the Palladian ideals, and the use of the Classical columns and their entablatures, used in many novel ways, At the universities Wren carried out many works bearing the impress of his Palladian training; amongst these the Sheldonian Theatre, Oxford, the Inner Court and Library of Trinity College, Cambridge, are prominent examples. A portion of Greenwich Hospital (the two blocks furthest from the river), in which the scale and treatment of Inigo Jones's design were followed, Chelsea Hospital, a portion of Hampton Court Palace, Morden College, Blackheath, and Temple Bar, London (now removed to Theobald's Park, Herts), are examples of his extraordinary facility in applying Palladian principles to various types of building, some of a simple character.

In the eighteenth century a great number of country houses were erected in England in which the traditional plans of Palladio, imitated and improved upon by Inigo Jones, and followed by others, were erected.

The pages of the "Vitruvius Britannicus," by Colin Campbell, will furnish plans and views of many of the most important houses erected during the century, and form an eloquent tribute to Palladian influence.

A few need only be mentioned, Rainham Hall in Norfolk, Castle Howard, by Sir John Vanbrugh, Kedlestone and Stowe House, by Robert Adam, are all notable as consisting of a central block of reception and family rooms with wings, quadrant or otherwise. In some cases, as at Kedlestone and Holkham Hall, by W. Kent (1730), there are four such wings. Similar types of plan are shown in Palladio, and must have influenced English architecture, as at Stoke Park, already mentioned. The peculiar Italian method of treating 
the ground floor as a basement storey for the kitchens and offices, and placing the principal apartments on the piano nobile or upper floor, is carried out in most of these buildings. In fact, the peculiarities of the Palladian style, and its inappropriateness when unaltered to suit the English climate, were referred to in strong terms by the satirists of the day.

Thus writes Pope in one of his epistles to the Earl of Burlington :
"You show us Rome was glorious not profuse And pompous buildings once were things of use. Yet shall, my lord, your just, your noble rules Fill half the land with imitating fools;
Who random drawings from your sheets shall take And of one beauty many blunders make;
Load some vain church with old theatric state, Turn arcs of triumph to a garden gate;
Shall call the winds through long arcades to roar, Proud to catch cold at a Venetian door."

Symmetry and grandeur were the qualities which predominated in eighteenth-century architecture, due in a large measure to the disciples of the Palladian School.

Nicholas Hawksmoor (I666-I763), Colin Campbell (d. I734), Sir John Vanbrugh (I666-I726), James Gibbs (I683I754), Thomas Archer (d. I743), William Talman (d. I7 I 5), the Earl of Burlington (I695-I753), Kent (I684-I748), Robert Adam (I728-I792), and Sir William Chambers (I726-I796), stand out pre-eminently as the followers of Palladio and Inigo Jones, and as the developers of the truly national elements of the English Renaissance.

Sir William Chambers by his writings, and especially his "Treatise on the Decorative Part of Civil Architecture," carried on the traditions of the Anglo-Palladian School, and 
objected to the Greek revival of architecture which was then beginning to be felt.

Thus till within a century ago the School of Palladio and his English followers was bound up with the traditions of English architecture. In the nineteenth century, tradition being broken up, the age of revivals commenced. The Greek, the Gothic and the Renaissance have each in turn been favoured by architects. At the present time, although the Renaissance style may be said to hold the field for all buildings save churches, it is of a very special kind, peculiar to England, and having no counterpart on the Continent.

We think that those who have studied the foregoing pages will see in the best of modern English architecture a good deal of the influence of our architect, in which simplicity and stateliness and a striving after repose are the chief qualities. 


\section{BIBLIOGRAPHY}

T 'ARCHITECTURE Universale. By Scamozzi. I694. Vita di Andrea Palladio. By Paolo Gualdo (published by Montanari). 8vo. Venice and Padoua, I749.

Vita di Andrea Palladio. By Temanza. 4to. Venice, I762, I778.

Vite dei piu Celebri Architetti. Temanza, Venezia, Palese, I778.

Della Basiliche Antiche e specialmente di quella di Vicenza. Discorso by Enea Arnaldi. Vicenza, I769. Capo XIII.

Bibl. degli Scrittori. P. A. G. Calvi. Vicenza, I772.

Histoire de la Vie et des Ouvrages des plus Célèbres Architectes. Quatremère-de-Quincy (A. C.). 2 vols. 4to. Paris, 1830.

The Quarterly Review. Vol. XXXII. I825.

Memorie degli Architetti. By Milizia (F.). I78I, ii. pp. 35-54.

Lives of Celebrated Architects. F. Milizia, translated by Mrs. Crecy. 2 vols., 8vo. London, 1826.

Letters of an Architect. Woods. 4to. London, I828.

Progetto di un Monumento a A. Palladio nel cimetero Vicentino da Matteo Osbolli. Vicenza, I836.

Palladian Edifices at Vicenza. By F. Arundale. I832.

Osservazioni sopra Andrea Palladio. Rigato. Padoua, I8I I.

A Collection of the most approved Examples of Door- 
ways, etc. ; preceded by a Sketch of the History of Italian Architecture. By T. L. Donaldson. London, 1836.

Notizie di A. Palladio. By F. Scolari (in "Lettera d'Appendice," etc., I837-I838 (R. I. B. A. Library).

L'Idea dell' Architettura Universale, per Cara di Stefano Ticozzi e Luigi Masieri. Milan, I838.

L'Architettura e la Scultura del Rinascimento in Venezia. 2 vols. Venice, I838-1840.

Le Fabbriche e i Monumenti cospicui di Venezi (Conte F. L. Cicognara). 2 vols., folio. Venice, 1838-1840.

Rome Moderne. Letarouilly. Paris, I840.

Memoria sul Sepolcro di A. Palladio, MSS., nella Bertoliana. Magrini.

Historical Essays on Architecture. By Hope. 3rd edition, 2 vols. London, I840.

Fabbriche e Terme. B. Scamozzi and C. Foppini. Part I. Folio. Geneva, I842.

Parere sulla Sepoltura del Palladio. Giuseppe Todeschini, 1844. MSS. nella Todeschini.

Vasari, Lives. 8vo. London, I852. iii. 444 ; v. 20r, 422 and 486.

Memorie Intorno la Vita e le Opere di A. Palladio. By Magrini. Vicenza, I845, and Padoua, I845-1846.

Dell' Architettura in Vicenza. Magrini. Vicenza, I845. Gloria della Belle Arti in Italia. Ranalli. Firenze, $\mathrm{I} 845$.

The Palladian School of Architecture. By W. Papworth, MS. ; 1848, I850 (R. I. B.A. Library).

Description of a Collection of Architectural Drawings at Chiswick, by A. Palladio, in the possession of the Duke of Devonshire at his villa at Chiswick; drawn up by Messrs. Poynter and Donaldson, and read as a Sessional Paper at the Royal Institute of British Architects, November I7th, 
I845. (Note.-These drawings are now in the R. I. B.A. Library.)

Teatro Olimpico in Vicenza. A. Magrini. 8vo. Padua, I847.

Il Palazzo del Museo Civico. Magrini. Vicenza, I855.

The Museum of Classical Antiquities. By Edward Falkener, I852.

Die Renaissance in Italien. Burckhardt. Stuttgart, I867. English edition, London, I89o.

Critical Notes by Waring. (Building News, I872, XXII. I80.

Studies in the History of the Renaissance. Walter Pater. London, I873.

Andrea Palladio e la sua Scuola. Vittoria Barichella. Lonigo, I880.

Gwilt's Encyclopaedia of Architecture. Revised and portions rewritten by Wyatt Papworth. London, I888.

An Elementary History of Art. N. D'Anvers. 3rd edition, London, I889.

The Burlington-Devonshire Collection of Drawings, formerly preserved in the Villa at Chiswick, with a note of that building. W. H. White. R. I. B. A. Transactions, vol. viii. N. S., I892.

The Dictionary of Architecture, issued by the Architectural Publication Society, with detached essays and illustrations. 6 vols. Folio. I848-I892.

Inigo Jones and Wren. By W. J. Loftie. London.

Renaissance in Italy: Fine Arts. J. A. Symonds. New edition, I 897 .

Some Architectural Works of Inigo Jones. By H. Inigo Triggs and Henry Tanner. I90 I. Batsford, London.

Renaissance and Modern Art. Goodyear. New York, I 894 . 
History of Architecture in all Countries. James Fergusson. 5 vols., 8vo. I893, etc.

Early Renaissance Architecture in England. By J. Alfred Gotch. I90 I. Batsford.

Calli e Canali in Venezia. Ongania. 2 vols. Venice, I890-I894.

A Short History of Renaissance Architecture in England. Reginald Blomfield. 8vo., I900. George Bell \& Sons.

A History of Architecture on the Comparative Method, by Professor Banister Fletcher and Banister Fletcher. 4th edition, I vol. London, I90I.

Baedeker's Guide to Northern Italy. 



